\title{
TRANSFORMAÇÕES NA AGROPECUÁRIA PARANAENSE E SUAS IMPLICAÇÕES SOBRE EMPREGO E SALÁRIOS RURAIS: 1977-96
}

\section{MÁRCIA ISTAKE}

Bacharel em Ciências Econômicas

Orientador: Prof. Dr. CARLOS JOSÉ CAETANO BACHA

Dissertação apresentada à Escola Superior de Agricultura "Luiz de Queiroz", Universidade de São Paulo, para obtenção do título de Mestre em Ciências, Área de Concentração: Economia Aplicada.

P I R A C I C A B A

Estado de São Paulo - Brasil

Fevereiro-1999 
Dados Internacionais de Catalogação na Publicação (CIP) DIVISĀO DE BIBLIOTECA E DOCUMENTAÇĀO - Campus "Luiz de Queiroz"/USP

Istake, Márcia

Transformaçōes na agropecuária paranaense e suas implicações sobre emprego e salários rurais: 1977-96 / Márcia lstake. - - Piracicaba, 1998.

$112 \mathrm{p}$.

Dissertação (mestrado) - - Escola Superior de Agricultura Luiz de Queiroz, 1998. Bibliografia.

1. Agropecuária 2. Emprego 3. Mão-de-obra 4. Mercado de trabalho agrícola 5. Paraná 6. Salário agrícola 7. Trabalhador rural 1. Título

CDD 331.763 


\section{DEDICO}

À Deus e meus anjos da guarda Aos meus pais Augusto e Rosa Ao meu amor Milton À minha alegria Maria Helena 


\section{AGRADECIMENTOS}

Ao DCO, em especial gostaria de agradecer aos amigos e professores Maria Júlia E. Leão, Jaime G. Trintin e Antonio Gomes Assupção por terem se comprometido, espontaneamente, a assumir encargos adicionais para que meu afastamento para fazer o mestrado pudesse ser concretizado.

À CAPES pela bolsa concedida, o que viabilizou financeiramente a realização do curso.

À minha família: Milton, Maria Helena, Augusto, Rosa, Marcelo, Maurício, Marisa, Juvelina, José e Liriana, pelo apoio, carinho, ajuda e compreensão sem a qual não teria conseguido concluir o curso.

Ao professor Dr. Carlos José Caetano Bacha pela orientação e compreensão em momentos difíceis que atravessei.

Aos funcionários e amigos do Departamento de Economia, Administração e Sociologia Rural da ESALQ: Maielli, Luciane, Cris, Helena, Valdeci, Pedro, Elenice, Maria Helena, Márcia e Angélica, muito obrigada pela atenção e pelo carinho.

Aos amigos que conquistei no curso, muito obrigada por vocês terem feito parte da minha vida e, principalmente, pela solidariedade que tiveram comigo sempre que precisei e por tudo que aprendi com vocês: Nancy, Edivaldo, Carlos, Rô, Dê, Gabi, Edson, Mau, Celi, Raul e Pedro.

Aos professores que participaram do seminário: Adriano e João Martinez e aos professores que participaram da qualificação e mini banca: Paulo F. Cidade e Mirian, a vocês agradeço pelas sugestões. A Luciane Bastos agradeço pela revisão em inglês.

Aos professores que fizeram parte da minha vida muito obrigada por terem me ensinado que aprender é um "barato" e que ensinar é mais "legal" ainda. 


\section{SUMÁRIO}

Página

LISTA DE TABELAS ........................................................................... viii

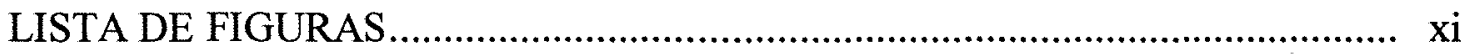

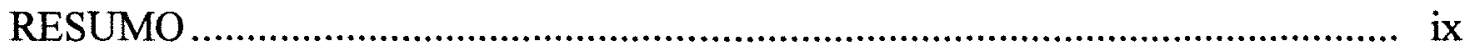

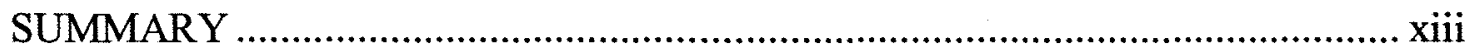

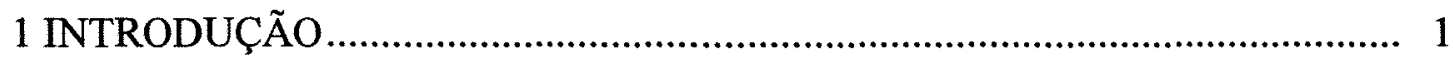

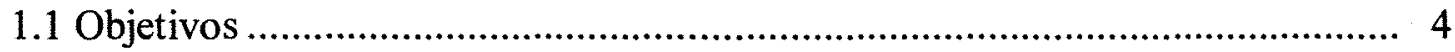

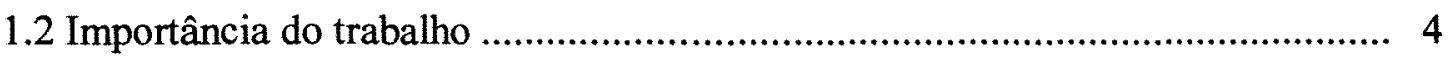

1.3 Organização do trabalho .................................................................. 5

2 REVISÃO DA LITERATURA SOBRE COMPORTAMENTO DO PESSOAL OCUPADO E DOS SALÁRIOS NO SETOR AGROPECUÁRIO BRASILEIRO E PARANANESE ......................................................... 6

2.1 Pessoal ocupado na agropecuária brasileira .......................................... 6

2.2 Renda do pessoal ocupado na atividade agropecuária no Brasil .................... 9

2.3 Comportamento do pessoal ocupado na agropecuária paranaense ................ 10

2.4 Salário do pessoal ocupado na agropecuária paranaense ............................ 12 
3 EVOLUÇÃO DA AGROPECUÁRIA E DA AGROINDÚSTRIA NO

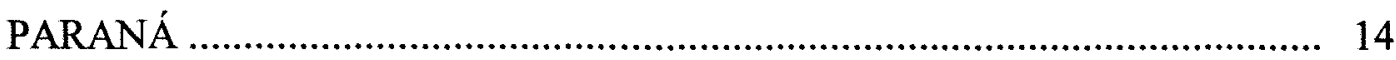

3.1 Evolução da agropecuária paranaense ....................................................... 14

3.1.1 Processo de ocupação do território paranaense ............................................. 15

3.2 Transformações recentes na agropecuária paranaense.................................. 18

3.2.1 A evolução da agropecuária paranaense de 1970 a1996 ............................... 18

3.2.2 Rebanho de bovinos, suinos e aves no Paraná............................................ 25

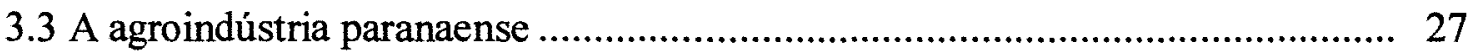

4 ASPECTOS METODOLÓGICOS E FONTES DE DADOS............................... 31

4.1 Fontes de informações sobre pessoal ocupado .................................................. 31

4.2 Revisão de alguns modelos utilizados para determinação dos salários no setor

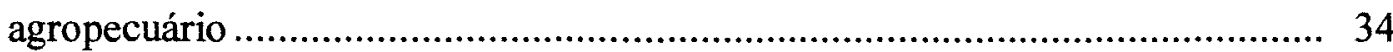

4.3 Descrição do modelo econométrico de determinação do salário rural a ser utilizado

4.3.1 Modelo econométrico para determinação do salário do trabalhador temporário

4.3.2 Modelo econométrico de determinação do salário do trabalhador permanente 44

4.3.3 Definição das variáveis utilizadas no modelo e as fontes dos dados............... 46

5 COMPORTAMENTO DO PESSOAL OCUPADO NA AGROPECUÁRIA DO

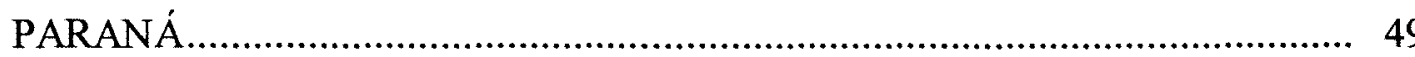

5.1 População rural no Paraná .................................................................................... 49 
5.2 Evolução e composição do pessoal ocupado na atividade agropecuária paranaense segundo os dados dos Censos Agropecuários............................... 52

5.3 Evolução e composição do pessoal ocupado na atividade agropecuária paranaense segundo os dados das PNADs................................................... 56

5.4 Qualificação da mão-de-obra envolvida nas atividades rurais do Paraná........... 62

6 ESTIMATIVAS DAS EQUAÇÕES DE DETERMINAÇÃO DOS SALÁRIOS . 67

6.1 Comportamento dos salários dos trabalhadores na agropecuária paranaense..... 67

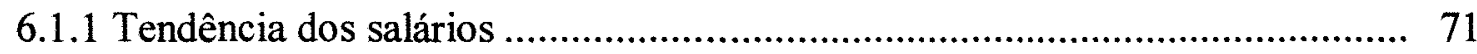

6.2 Comportamento das demais variáveis que compõem os modelos de determinação dos salários ...................................................................... 77

6.3 Determinantes dos salários dos trabalhadores da agropecuária paranaense $\quad$...... 79

6.3.1 Determinantes do salário do tratorista (WT) _......................................... 81

6.3.2 Determinantes do salário do mensalista (Wmen) ........................................ 83

6.3.3 Determinantes do salário do trabalhador temporário (WV) ......................... 86

7 CONCLUSÃO

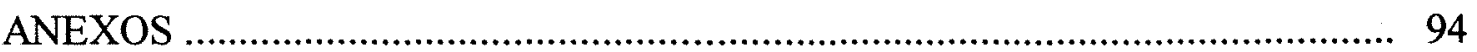

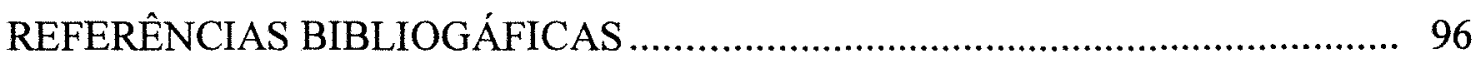

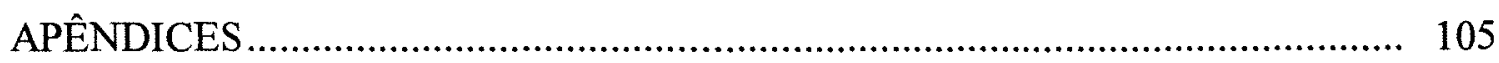




\section{LISTA DE TABELAS}

\section{Página}

1 Uso de tratores e adubos (químico e orgânico) na agropecuária do Paraná: $1970,75,80,85$ e 96

2 Variação absoluta (em ha) e percentual na área total dos estabelecimentos agropecuários, por grupos de área no Paraná, 1970-80, 1980-85 e 1985-95 ...... 20

3 Taxas anuais de crescimento da produtividade da terra nas principais atividades agrícolas do Paraná, 1970-79 e 1980-96

4 Participação percentual da área destinada ao cultivo das principais atividades agrícolas no Paraná, 1970, 75, 80, 85, 90 e 96

5 Taxa anual de crescimento da produção agroindustrial no Paraná, no período $1981-93$

6 Participação das regiões Nordeste, Sudeste, Sul e Centro-Oeste na quantidade de soja em grãos processada no Brasil, safras 92/93 - 95/96

7 População total, rural e urbana no Paraná em valores absolutos e participação percentual, 1940, 50, 60, 70, 80, 91 e 96 (valores absolutos em milhares).

8 Taxa de crescimento e participação do pessoal ocupado na agropecuária paranaense, 1970-95, segundo as classes de atividade econômica

9 Taxa de crescimento e participação percentual das diversas categorias no pessoal ocupado na agropecuária, Paraná, 1970, 75, 80, 85 e 95 
10 Categorias de pessoas ocupadas que tinham trabalho na semana de referência na atividade agropecuária no Paraná, 1981-90 ………...................................... 57

11 Categorias de pessoas ocupadas que tinham trabalho na semana de referência na atividade agropecuária no Paraná, 1992-96 .................................................. 58

12 Distribuição percentual das pessoas ocupadas nas atividades rurais no Paraná, $1992,93,95$ e 96

13 Participação do tipo de ocupação nas atividades desenvolvidas no meio rural do Paraná, 1992, 93, 95 e 96 (valores em percentuais)

14 Nível de escolaridade, participação percentual e taxa de crescimento para o trabalhador da agropecuária no Paraná, 1970 e 1991

15 Participação percentual da mão-de-obra qualificada e não qualificada nas atividades agropecuárias e de extração vegetal, Paraná, 1970, 1980 e 1991 ..... 63

16 Participação percentual das ocupações exercidas na semana de referência nas atividades rurais no Paraná, 1922, 93, 95 e 96

17 Tipos de vínculos empregatícios encontrados nas ocupações do operador agrícola e dos trabalhadores rural no Paraná, 1992, 93, 95 e 96

18 Participação das pessoas ocupadas nas atividades agropecuárias com 10 anos ou mais de idade, segundo as classes de rendimento médio mensal em salários mínimos, Paraná, 1980 e 1991

19 Número de salários mínimos que os trabalhadores rurais recebiam no Paraná e taxa de crescimento, 1977-96

20 Dados utilizados para estimativas das equações de determinação dos salários dos trabalhadores rurais no Paraná e suas taxas de crescimento, 1977-96 


\section{LISTA DE TABELAS DOS APÊNDICES}

1.1 Dados utilizados para a estimativa da tendência dos salários dos trabalhadores nas atividades agrícolas no Paraná, 1977-96

2.1 Dados utilizados para estimativa da equação de determinação do salário do tratorista no Paraná, 1977 a 1996................................................................. 108

2.2 Dados utilizados para estimativa da equação de determinação do salário do mensalista no Paraná, 1977 a 1996 .......................................................................

2.3 Dados utilizados para estimativa da equação de determinação do salário do diarista no Paraná, 1977 a 1996. 


\section{LISTA DE FIGURAS}

\section{Página}

1 Taxa de crescimento da área média dos estabelecimentos agropecuários $\left(\mathrm{ha} / \mathrm{n}^{\mathrm{o}}\right.$ de estabelecimentos), Paraná, 1970-96

2 Volume de crédito rural por área (crédito/área) destinado à atividade agrícola no Paraná, 1979-95

3 Índice de evolução do rebanho de bovinos, suínos e aves no Paraná, 1981-96.... 26

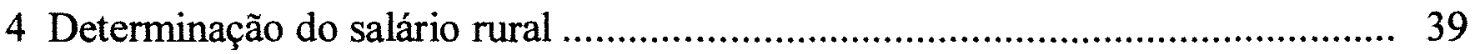

5 Participação das posições na ocupação das pessoas ocupadas na atividade agropecuária no Paraná, 1981-95.............................................................. 59

6 Número de salários mínimos que os mensalistas, tratoristas e diaristas recebiam no Paraná, 1977-96

7 Taxa de crescimento das ocupações agropecuárias no Paraná, 1970-80 e 198091

8 Salários dos trabalhadores permanentes e suas tendências, Paraná 1977-96 ........ 72

9 Salário do trabalhador temporário e sua tendência, Paraná 1977-96................... 72

10 Salário do tratorista observado e estimativa da tendência, Paraná 1977-96 ....... 74 
11 Salário do mensalista observado e estimativa da tendência, Paraná 1977-96..... 75

12 Salário do diarista observado e estimativa da tendência no Paraná, 1977-96..... 76

LISTA DE FIGURAS DO ANEXO “A”

Al Evolução do salário mínimo no Brasil, 1977-96 ............................................... 95

A2 Evolução do salário dos serventes na indústria da construção civil de São Paulo 95

A3 Evolução do lucro (relação entre preços recebidos/pagos) dos produtores rurais do Paraná, 1977-96 ...................................................................... 95

A4 Evolução da produtividade da mão-de-obra na agricultura brasileira, 1977-96 . 95

A5 Evolução da produção total (T) na agricultura paranaense, 1977-96

A6 Evoluçãa do índice de preços recebidos pelos produtores rurais no Paraná, $1977-96$ 


\title{
TRANSFORMAÇÕES NA AGROPECUÁRIA PARANAENSE E SUAS IMPLICAÇÕES SOBRE EMPREGO E SALÁRIOS RURAIS: \\ 1977-96
}

\author{
Autora: MÁRCIA ISTAKE \\ Orientador: Prof. Dr. CARLOS JOSÉ CAETANO BACHA
}

\section{RESUMO}

Este estudo analisa o comportamento do emprego e dos salários na agropecuária paranaense no período de 1977 a 1996.

São utilizados dados dos Censos Agropecuários e Demográficos e das PNADs (Pesquisa Nacional por Amostra de Domicílio), publicações e microdados individuais, para avaliar o comportamento do emprego na agropecuária paranaense. Observa-se uma tendência de queda na participação do subsetor agricultura (lavouras) na geração de empregos, dentro da agropecuária, mais ainda assim aquela é a principal atividade a empregar no meio rural. Verifica-se, também, a grande importância da agricultura familiar (conta-própria) e da mão-de-obra não remunerada no total de pessoas ocupadas na agropecuária. A atividade de maior importância na absorção da mão-de-obra rural no Paraná, em anos mais recentes, foi o milho, que contou, em sua 
grande maioria, com a utilização da mão-de-obra familiar e da sem remuneração. Com relação à especialização da mão-de-obra, constata-se uma tendência à redução na participação da mão-de-obra não qualificada e aumento na participação da mão-de-obra qualificada no total de pessoas envolvidas com as atividades rurais.

Verifica-se, no período de 1985 a 1995, de acordo com os dados dos Censos Agropecuários do Paraná, uma grande concentração de área em propriedades rurais de médio e grande portes e uma redução de área nas pequenas propriedades e nos latifúndios. Os dados registram, também, a maior queda no emprego rural observada no últimos tempos, $-30,59 \%$ entre 1985 e 1995. Esta redução superou o volume de empregos eliminados na década de 70, em função da modernização da agropecuária.

Com relação ao comportamento dos salários dos trabalhadores rurais, investigaram-se duas categorias de trabalhadores permanentes (o mensalista e o tratorista) e uma de trabalhador temporário, o diarista. Verifica-se quebra de tendência com relação ao comportamento do salário dos trabalhadores permanentes, no ano de 1987, e aumento no piso salarial destes trabalhadores, em termos de salário mínimo, a partir de então os salários reais dos trabalhadores permanentes diminuíram de 1977 a 1987, elevando-se a partir de 1988 até 1996. Para o salário do trabalhador temporário, a quebra de tendência deu-se em 1988 e foi a categoria que obteve a menor taxa de crescimento do piso salarial em termos de salário mínimo.

Constata-se que os principais determinantes dos salários dos trabalhadores permanentes no $1^{\circ}$ período $(1977 / 86)$ foram o lucro e o salário mínimo. Os cálculos das elasticidades demostram a maior importância do salário mínimo na determinação dos salários destes trabalhadores.

No segundo período (1987/96), os principais determinantes dos salários do tratorista foram a produtividade da mão-de-obra, o salário mínimo e o lucro. Para o caso do mensalista, além dos determinantes acima mencionados incluiu-se, também, a variável produção total. Os cálculos das elasticidades demostram a importância da produtividade da mão-de-obra na determinação dos salários dos 
tratoristas e mensalistas no $2^{\underline{0}}$ periodo, e a diminuição de importância do salário mínimo na determinação do salário do trabalhador permanente no segundo período, na agropecuária paranaense.

Para o trabalhador temporário, o determinante principal do seu salário no primeiro período foi apenas o salário mínimo. Os cálculos das elasticidades para o segundo período demostram a maior importância da produção total e da produtividade da mão-de-obra na determinação do salário do diarista. Os preços recebidos pelos produtores agropecuários no Paraná influenciaram, também, o salário do diarista, mas, em menor proporção. 


\title{
CHANGES IN PARANÁ LIVESTOCK AN AGRICULTURE AND THEIRS IMPLICATIONS ON EMPLOYMENT AND RURAL WAGES: FROM 1977 TO 1996
}

\author{
Author: MÁRCIA ISTAKE \\ Advisor: Prof. Dr. CARLOS JOSÉ CAETANO BACHA
}

\section{SUMMARY}

This study analyzes the behavior of employment and wages in Paraná agriculture during the period from 1977 to 1996.

Data of Agricultural and Demographic Census and PNADs (Pesquisa Nacional por Amostra de Domicilio), publications and individual data, were used to evaluate the employment behavior in the Parana agriculture. A downward was observed in the participation of agriculture in employment rate development, however agriculture keeps being the main activity to employ in rural area. Also, there is a great importance of the family agriculture (on its own account) and non paid labor in the total of people who work in livestock and agriculture. Corn has been the activity of greatest importance in the absorption of labor in Paraná agriculture, in recent years, such, culture in its majority counted with the use of the family and non paid labor. Regarding to the specialization of labor, a reduction in the participation of non qualified labor and an 
inerease in the participation of qualified is verified in the total workers involved with rural activities.

It is observed, from 1985 to 1995 , in according to Paraná Agricultural Census, a great area concentration in medium and large farms, and a reduction of area in small farms and in largest one. Data also register the largest fall in the rural employment during recent years, $-30,59 \%$ from 1985 to 1995 . This reduction overcame the volume of jobs that was extinguished in 70 's, due to agricultural modernization.

As for rural worker's wages behavior, two categories of permanent workers are investigated (monthly wages and tractor drivers), and one of temporary worker (daily help). It was verified an interruption tendency regarding to behavior of permanent workers' wage in 1987, and an increase in there workers' salary level, in terms of minimum wage, since then. Concerning to temporary workers' wage the interruption of tendency occurred in 1988 and it was the category that obtained the smallest rate of salary level increase in terms of minimum wage.

It is verified the main determinants of the permanent workers' wages in the first period (1977/86) were profit and minimum wage. The calculations of elasticities show the importance of the minimum wage in the determination of these workers' wages.

In the second period (1987/96), the main determinants of tractor driver's wages were productivity of labor, minimum wage and profit. For the case of monthly workers' wages, besides above mentioned determinants, was also included total production. The calculations of elasticities show the importance of labor productivity in the determination of the wages for tractor drivers and monthly workers' wages in the second period, and the decrease of importance of minimum salary in the determination of permanent worker's wage in the second period of Paraná agriculture. 
For temporary workers, the main wage determinant from 1977 to 1996 was minimum wage. The calculations of elasticities for second period demonstrate the importance of total production and labor in daily worker's wage. Agricultural prices, received by farmers in Paraná, also influenced daily worker's wages, but in a smallest scale. 


\section{INTRODUÇÃo}

Este trabalho analisa o comportamento do emprego e dos salários na agropecuária paranaense, no período de 1977 a 1996. Durante este período ocorreram expressivas taxas de crescimento e transformações na agropecuária paranaense.

O Paraná destaca-se no contexto nacional pelo grande dinamismo de suas atividades agropecuárias e agroindustriais. De acordo com Silva \& Considera (1996), em 1994 o Paraná foi responsável pela geração de 6,74\% do Produto Interno Bruto (PIB) brasileiro e por 9,38\% do PIB agropecuário nacional. No Censo Industrial de 1980, para o Paraná, verifica-se que a agroindústria era muito importante no setor industrial deste Estado. Estima-se que a agroindústria foi responsável por $27 \%$ dos estabelecimentos totais da indústria, por $37 \%$ do valor da produção e por $20 \%$ do pessoal total ocupado na indústria em 1980 .

Entre as 35 culturas pesquisadas pelo Anuário Estatístico do Brasil de 1995, em 1994 o Paraná foi o principal produtor de 5 culturas (trigo, milho, feijão, batata inglesa e algodão herbáceo), o segundo maior produtor de 5 culturas (soja, mandioca, cevada, centeio e aveia), o terceiro maior produtor de fumo e o quarto maior produtor de café e amendoim. Este Estado também destaca-se na produção pecuária e florestal.

A pauta de produtos da agricultura paranaense modificou-se na década de 70. Segundo dados do Anuário Estatístico do Brasil e do Acompanhamento da Situação Agropecuária no Paraná, o café, que até então era uma das principais atividades 
agrícolas do Estado, responsável por 27,16\% da área cultivada em 1968, perdeu importância frente a outras culturas, tais como: soja e trigo. $O$ café passou a representar apenas 8,66\% da área cultivada no Estado em 1980 e 1,78\% em 1996. A soja, nos anos 70, teve sua área cultivada significativamente aumentada em relação às demais culturas, apresentando um aumento de cerca de $900 \%$.

Nos anos 80 e 90 a soja, o milho e o trigo foram as principais atividades agrícolas do Estado. Em 1980 estas culturas ocupavam 70,83\% da área destinada a agricultura no Paraná, passando a 78,26\% da área agrícola em 1996.

Os alicerces sobre os quais encontra-se a estrutura produtiva agropecuária existente hoje no Paraná foram construídos, principalmente, ao longo da década de 70. Neste período, a agricultura do Estado iniciou profundas transformações, em decorrência da modificação na função de produção, o que está associada à expansão, em bases modernas, do binômio soja/trigo. Segundo Hespanhol \& Costa (1994), a disponibilidade de crédito fácil e barato para estas culturas, durante a década de 70 , possibilitou a expansão do uso de máquinas e insumos industriais, alterando o padrão tecnológico adotado até então.

No Paraná houve um grande aumento no consumo dos produtos ofertados pela indústria para a agropecuária. Com relação à tração mecânica, observouse que nos anos 70 cresceu significativamente o número de tratores e colhedeiras utilizados pelos produtores $(383,9 \%$ e $123,5 \%$, respectivamente, segundo dados dos Censos Agropecuários de 1970 e 1980).

A política de crédito rural, adotada pelo Governo Federal, teve importância significativa na explicação das transformações ocorridas na agricultura paranaense, devido, principalmente, ao grande volume de recursos e subsídios repassados ao setor. Martins \& Massola (1994) distinguem as diferentes fases do repasse do crédito de custeio aos agricultores do Estado. "O período de 1974-75 caracterizou-se por taxas reais de juros negativas e expansão no volume de crédito, situação essa que já vinha 


\subsection{Objetivos}

O objetivo geral deste trabalho é analisar como se comportaram emprego e os salários na agropecuária paranaense no período de 1977 a 1996.

\section{Como objetivos especificos tem-se:}

i) analisar as transformações que ocorreram na agropecuária paranaense nas décadas de 80 e 90 ;

ii) analisar a evolução e a composição do pessoal ocupado na agropecuária paranaense nas décadas de 80 e 90;

iii) avaliar o comportamento dos salários na agropecuária paranaense no período de 1977 a 1996; e,

iv) estimar equações de determinação dos salários rurais, no periodo de 1977 a 1996.

A escolha do periodo 1977 a 1996 deve-se à disponibilidade de dados sobre salários e emprego $\mathrm{e}$, também, pelo fato desse período presenciar transformações na agropecuária paranaense.

\subsection{Importância do trabalho}

Atualmente, o desemprego é um dos grandes problemas enfrentados pelas sociedades contemporâneas. Balsadi (1996) ressalta que, tanto nos países centrais quanto nos periféricos, o desemprego é agravado em função das profundas mudanças tecnológicas que tornaram o trabalho humano redundante. Dados do Banco Mundial (1996) mostram que no mundo existem aproximadamente 120 milhões de trabalhadores desempregados.

Dentro desta preocupação, é importante um estudo que mostre os impactos sofridos pelas diversas categorias de trabalhadores rurais do Paraná após 
iniciadas as transformações na agropecuária deste Estado, avaliando o comportamento do emprego e dos salários.

Evidenciando-se os principais determinantes dos salários dos trabalhadores rurais, as principais atividades a empregar no meio rural, a forma de ocupação do pessoal ocupado nas atividades agropecuárias, etc..., pode-se sinalizar para algumas tendências que poderão servir de subsídios às futuras políticas a serem implantadas na agropecuária paranaense.

\subsection{Organização do trabalho}

Além desse capítulo introdutório, o trabalho compõe-se de mais seis capítulos. O capítulo 2 faz uma revisão dos trabalhos já realizados sobre emprego e salário na agropecuária brasileira e paranaense. O capítulo 3 analisa a evolução da agropecuária e agroindústria do Paraná entre 1975 e 1996, abrangendo o período de modernização com crédito abundante e barato, e as transformações que ocorreram após o periodo de crédito subsidiado. No capítulo 4 são discutidos os aspectos metodológicos e as fontes de dados utilizados neste trabalho. $\mathrm{O}$ capítulo 5 discute a evolução e a composição da mão-de-obra na agropecuária paranaense. O comportamento dos salários dos trabalhadores agropecuários paranaenses é analisado no capítulo 6 . A conclusão do trabalho faz-se no capitulo 7 


\section{REVISÃO DA LITERATURA SOBRE COMPORTAMENTO DO PESSOAL OCUPADO E DOS SALÁRIOS NO SETOR AGROPECUÁRIO BRASILEIRO E PARANAENSE}

São apresentados, a seguir, alguns trabalhos que discutem questões relativas ao comportamento do emprego e dos salários na agropecuária ${ }^{1}$ brasileira e paranaense. Não se espera abordar toda a literatura, mas, mostrar as principais conclusões que se têm nos âmbitos de Brasil e Paraná sobre esses dois temas (emprego e salário).

\subsection{Pessoal ocupado na agropecuária brasileira}

A importância da agropecuária na geração de empregos é mais significativa em paises de baixa renda. O Banco Mundial (1996) mostrou que nos países pobres $61 \%$ da força de trabalho dedicava-se à agricultura, principalmente a de subsistência familiar. Nos países de renda média, cerca de $29 \%$ da força de trabalho trabalhava nas fazendas e $18 \%$ dedicava-se às atividades rurais e urbanas informais. Já nos países ricos apenas $4 \%$ da força de trabalho ocupava-se na atividade agrícola. No Brasil, segundo dados do Anuário Estatístico do Brasil (1993), em 1990 22,8\% das pessoas ocupadas com 10 anos ou mais de idade estavam na atividade agropecuária.

\footnotetext{
${ }^{1}$ Boa parte dos textos não distingue agricultura e agropecuária. Assim, procura-se manter o termo original dos trabalhos citados, sendo que a palavra agricultura se refere à agropecuária, a não ser que seja dito o contrário.
} 
Silva \& Kageyama (1983b), analisando os dados do Censo Agropecuário, observaram comportamentos distintos das taxas anuais de crescimento da mão-de-obra agrícola ocupada em São Paulo e no Brasil, entre 1960 e 1970. Esses autores verificaram uma rápida redução no volume de mão-de-obra contratada diretamente pelos estabelecimentos agropecuários no estado de São Paulo, enquanto que o seu volume apresentou expansão a taxas moderadas no Brasil como um todo.

Com relação ao pessoal ocupado na agricultura brasileira na década de 70, Silva \& Kageyama (1983a) apontaram duas características que marcaram a passagem da $1^{\underline{a}}$ para a $2^{\underline{a}}$ metade dos anos 70 , que são:

a) forte declínio da taxa de crescimento do número de pessoas ocupadas entre 1975 e 1980 em relação a 1970/75, tanto no Brasil quanto na maior parte de suas regiões; e,

b) redução da participação de mulheres e crianças na força de trabalho, em todas as regiões do País.

As razões que os autores acreditam serem responsáveis por estes fatos são: modernização da agricultura, queda cíclica da atividade econômica do País e concentração fundiária (com redução das pequenas unidades familiares).

Surgiram algumas polêmicas sobre a evolução e a composição do emprego agrícola na década de 80. Alguns autores (Mueller, 1987; e Silva, 1987), analisando os Censos Agropecuários de 1980 e 1985, constataram um grande crescimento da população ocupada na agropecuária, que foi entendido como um processo de minifundização. De outro lado, Aguirre \& Bacha (1989a,b) analisaram os dados da PNAD (Pesquisa Nacional por Amostra em Domicílio), argumentando que o crescimento do pessoal ocupado foi na categoria de empregados.

Martine \& Arias (1987), analisando os dados dos Censos Agropecuários de 1975, 80 e 85, mostraram que no qüinqüênio 1975-80 o número de pessoas ocupadas na agricultura cresceu apenas $4 \%$, ou seja, pouco mais de 818 mil 
pessoas. No qüinqüênio subsequente, a expansão foi de $11 \%$, com acréscimo de mais de 2 milhões de pessoas.

Silva (1987), por sua vez, concluiu que o aumento de pessoas ocupadas na agropecuária, entre 1980 e 1985, não foi do nível de emprego na agricultura brasileira, mas da subocupação e do subemprego no campo.

Mueller (1987), ao analisar os dados da Sinopse do Censo Agropecuário de 1985, comentou que os novos pequenos estabelecimentos tiveram papel importante na absorção do incremento de mão-de-obra rural entre 1980 e 1985.

Entretanto, Aguirre \& Bacha (1989a) observaram que tanto no Brasil quanto nas suas macrorregiões houve uma tendência do avanço dos empregados e redução nas categorias dos conta-própria e não-remunerados.

O trabalho de Carvalho (1993) procurou verificar se esse aumento das pessoas ocupadas na agricultura brasileira implicou realmente na volta à agricultura de subsistência, gerando assim, como concluiu Silva (1987), subemprego e subocupação no campo. Para tanto, utilizou-se das seguintes informações: decomposição da mão-de-obra por categoria, faixa etária e sexo; produtividade do trabalho e evolução dos salários rural e urbano. A autora em questão concluiu que suas análises não the possibilitavam afirmar que o aumento do número de pessoas ocupadas no campo entre 1980-85 foi um processo de subocupação, como ressaltou Silva (1987).

Mais recentemente, Silva (1996a), analisando os dados das PNADs de 1981 e 1990 para a PEA (População Economicamente Ativa) de 10 anos ou mais ocupadas em atividades agropecuárias e da PEA residente na zona rural, chegou às seguintes conclusões:

a) o crescimento da PEA rural é muito maior que o da PEA agrícola nos anos 80 . "Em 1990, a PEA rural supera a PEA agrícola em mais de 2,5 milhões de pessoas; além disso a sua taxa de crescimento é três vezes maior" (Silva, 1996a, p. 352); e, 
b) a taxa média de crescimento da PEA agricola, embora baixa, foi positiva no periodo, tanto para a parcela que reside na área urbana quanto para a residente na área rural.

Com esta constatação, o autor chama atenção para o crescimento de atividades não agrícolas no meio rural.

\subsection{Renda do pessoal ocupado na atividade agropecuária no Brasil}

As mudanças na agropecuária brasileira após a década de 70 colocaram o Brasil no grupo dos países emergentes em termos desse setor. Entretanto, Gonçalves (1996) destaca que, no tocante à questão social, essa mesma agropecuária continuava a revelar todas as imperfeições de um pais "atrasado" (com concentração da posse da terra e da renda).

A distribuição de renda e a pobreza na agricultura brasileira são temas abordados por Hoffmann (1992), o qual chegou às seguintes conclusões:

a) no decorrer da década de 70 , em função do processo de modernização pelo qual passou a agricultura brasileira, ocorreu, neste setor, um grande crescimento do rendimento médio, mas ao mesmo tempo, observou-se um aumento extraordinário nas desigualdades da distribuição de renda no setor; e,

b) na década de 80 , verificou-se um agravamento da situação constatada na década anterior.

No que se refere ao rendimento das pessoas ocupadas no setor agricola do País, Hoffimann (1992) observou que a proporção de pessoas economicamente ativas na agricultura brasileira, com rendimento real inferior a um salário mínimo de agosto de 1980, era de 81,4\% em 1970 e 59,5\% em 1980 . O autor chamou atenção para o fato de que, apesar dos valores indicarem redução na pobreza, isso não implicou redução na desigualdade de distribuição de renda. 
Kageyama \& Rehder (1993, p. 37) concluíram, com relação aos indicadores de renda e pobreza da população rural brasileira, que "na grande maioria dos estados a década de 80 foi marcada por uma queda real na renda per capita na agricultura, com aumento generalizado da pobreza (em termos apenas de renda), o que por si só revela a precariedade da situação social no campo dos anos $90^{\prime \prime}$.

O diferencial de renda do setor agrícola e não-agrícola foi analisado por Silva (1996a) que, utilizando dados das PNADs, mostrou que no caso brasileiro as rendas não-agrícolas são substancialmente maiores que as rendas agrícolas dentro de uma mesma região no País ${ }^{2}$.

\subsection{Comportamento do pessoal ocupado na agropecuária paranaense}

Em geral, a preocupação de grande parte dos trabalhos que analisaram a questão do emprego na agricultura paranaense encontra-se mais centrada na intensa redução da população rural nos anos 70 , como resultado das mudanças tecnológicas e da substituição de culturas.

IPARDES (1981b) discutiu questões ligadas ao mercado de trabalho agrícola, onde avaliou as condições de trabalho, a demanda e oferta potencial de mão-de-obra. Foram evidenciadas as conseqüências da redução da população rural para o setor agrícola, refletindo em diminuição na oferta futura de trabalho para este: “( ...) uma redução acentuada da população rural, no período $70 / 80$, poderia acarretar dificuldades aos trabalhos rurais, mesmo que o processo de modernização das atividades agrícolas tenha sido intenso, pois a modernização teria restrições topográficas em algumas regiões, e mais sérias ainda, as restrições de ordem econômica na adoção de inovações" (IPARDES, 1981 b, p.30)

${ }^{2}$ Como alternativa para que as pessoas do meio rural tivessem suas rendas aumentadas, Silva (1996a) sugeriu que as mesmas mudassem para as cidades ou que mudassem 0 ramo de atividade e continuassem a residir no meio rural. $O$ autor citou como alternativa as seguintes atividades rurais nãoagrícolas: agroindústria rural, atividades relacionadas ao meio ambiente e sítios de recreio. 
No que se refere ao emprego agrícola paranaense na década de 70, IPARDES (1983) constatou a redução no número de pessoas ocupadas em atividades agropecuárias, destacando que esta diminuição não deve ser atribuída à falta de dinamismo da agricultura, pois esta tem aumentado sua área cultivada e sua produtividade por hectare nessa década. Este trabalho atribuiu à nova base tecnológica, que passou a ser utilizada na agricultura, o fato de a demanda por trabalho na zona rural ter decrescido.

Quanto à categoria de trabalhador que mais perdeu posto de trabalho na década de 70, IPARDES (fev./83) verificou um decréscimo nas categorias de arrendatários, parceiros e ocupantes. Apontou, também, a região Norte do Estado (antiga região cafeeira) como a principal responsável pela significativa redução no número de empregos no setor agrícola, pois “(..$)$ foi aí que ocorreram as maiores transformações de emprego rural (...) refletindo dessa maneira a tendência negativa observada na diminuição absoluta da população rural" (IPARDES, fev./83, p. 26)

Istake (1992) verificou que a substituição da cafeicultura pela soja foi responsável por uma parcela expressiva da redução de pessoal ocupado na atividade agrícola no Paraná na década de 70 . A autora estimou que aproximadamente 200 mil empregos foram destruídos frente a substituição do café pela soja nesse período. Ressaltou-se, entretanto, que este fato não foi mais tão significativo no primeiro qüinqüênio da década de 80 .

Carvalho (1993) verificou que, no Paraná, a categoria de empregados no setor agropecuário aumentou na década de 80 .

Zanchet (1996), analisando dados da PNAD de 1990 a 1995, concluiu que cerca de 237 mil pessoas perderam postos de trabalho no setor agrícola, incluindo as categorias de empregados, trabalhadores por conta própria e pessoas não remuneradas da familia, as quais correspondiam também às categorias mais importantes em termos quantitativos. 
Zanchet (1996) também observou que, em 1995, das 4.364 mil pessoas ocupadas no Paraná, cerca de 1.344 mil encontravam no setor agrícola a fonte de renda de seu trabalho principal, o que correspondia a $30,8 \%$ do total de pessoas ocupadas no Estado.

\subsection{Salário do pessoal ocupado na agropecuária paranaense}

Com relação ao comportamento dos salários dos trabalhadores rurais, verifica-se uma carência de trabalhos que destaquem as diferenças salariais das diversas categorias de trabalhadores, bem como seus determinantes e sua evolução nos anos 80 e 90 .

IPARDES (1981) verificou os niveis de rendimento do pessoal ocupado e dos chefes de família ligados às atividades agropecuárias. Concluiu que $45,66 \%$ da população economicamente ativa ligada a esta atividade recebiam menos que um salário mínimo, configurando, assim, uma situação de vigência de baixos niveis salariais na década de 70. Cabe, entretanto, ressaltar que neste trabalho o autor considerou os rendimentos e não apenas o salário do pessoal ocupado.

Guisser (1975) buscou, através de estudo econométrico, mostrar que um alto nivel de escolaridade estimula a migração rural. Este estudo foi feito para os Estados Unidos. Com base na metodologia descrita e utilizada por Guisser (1975), Campos (1998) estimou curvas de oferta e demanda por trabalho no meio rural paranaense, nos anos 1970 e 1980, objetivando verificar o efeito da escolaridade sobre o salário dos trabalhadores rurais. Analisou, também, o comportamento da força de trabalho, a relação área/trabalhador e o estoque de capital.

Campos (1988) concluiu que a escolaridade mostrou-se importante na determinação dos rendimentos dos trabalhadores rurais, principalmente, para as equações de oferta. No que se refere às equações de demanda, Campos (1998) 
verifica que a qualificação do trabalhador rural não teve efeito significativo na contratação deste nas atividades rurais do Estado em 1970 e 1980.

Após o resumo acima realizado, constata-se uma lacuna no que diz respeito a estudos recentes referente ao pessoal ocupado e salário na atividade agropecuária no Estado. Ainda não temos trabalhos que observem, ao longo do período de 1977 a 1996, a evolução das diversas categorias de pessoal ocupado neste setor, bem como sua especialização e o comportamento e os determinantes dos salários. 


\section{EVOLUÇÃo dA AGROPECUÁRIA E DA AGROINDÚSTRIA NO PARANÁ}

O presente capítulo analisa a evolução da agropecuária e da agroindústria paranaense, observando o processo de ocupação de seu território, as transformações e o comportamento recente da agricultura, do rebanho bovino, suíno, de aves e da agroindústria no Estado.

\subsection{Evolução da agropecuária paranaense}

A agropecuária do Paraná tem peso significativo junto à brasileira. Aquela gera cerca de $20 \%$ da produção total de grãos no Brasil, de acordo com o Anuário Estatístico do Brasil (1994). As principais atividades agropecuárias no Paraná são: soja, milho, trigo, algodão, cana-de-açúcar, mandioca, bovinocultuta, avicultura e suinocultura.

A importância da agropecuária na formação do PIB paranaense não deve ser apenas medida levando em consideração sua produção in natura (que gerou $11,7 \%$ do PIB paranaense em 1994) mas, sim, toda a cadeia produtiva a ela relacionada, o que, com certeza, eleva bastante este percentual.

Para entender o processo de evolução da agropecuária e da agroindústria paranaense, faz-se necessário verificar como foi a ocupação do seu território, bem como os diversos ciclos econômicos pelos quais passou a economia deste Estado. Cabe ressaltar, entretanto, que estes ciclos econômicos encontraram-se 
relacionados aos ciclos econômicos gerais do Brasil (que fazem parte do processo global de formação econômica do País).

\subsubsection{Processo de ocupação do território paranaense}

Segundo Silva (1996b), a agricultura tem uma particularidade em relação à indústria, ou seja, o meio de produção mais importante, a terra, não é suscetível de multiplicação ao livre arbítrio do homem. Por ser a terra um meio de produção que não pode ser produzido, como as máquinas, a maneira como se dá sua ocupação histórica inicial é importante para entender a estrutura fundiária existente.

A ocupação da área do atual estado do Paraná encontra-se relacionada aos ciclos econômicos pelos quais passou sua economia. Os ciclos que merecem destaque são: o do escravo-indígena, o do ouro, o do tropeirismo, o da ervamate e da madeira, e o do café. Como o trabalho não objetiva discutir em detalhes os diversos ciclos econômicos envolvidos no processo de ocupação do território do Estado, eles são tratados de forma bastante sucinta.

A ocupação do território que hoje constitui o Paraná deu-se de forma lenta e descontínua. A princípio, no início do século XVI, a penetração nesse território tinha como principal objetivo a caça ao índio, para fins de trabalho escravo. A busca ao índio foi realizada numa ampla área compreendendo o Norte, Oeste e CentroSul. Essas penetrações na busca ao tupiniquim propiciaram a descoberta do ouro nos riachos oriundos da Serra do Mar.

Em fins do século XVI, a busca pelo ouro fez surgir os primeiros povoados do litoral paranaense. Como conseqüência da mineração, ocorreu, também, a colonização do primeiro planalto, a abertura de picadas que ligaram o planalto curitibano ao litoral, e a fundação de Curitiba (Konzen \& Zapparoli, 1990). Com o esgotamento do ouro na região, estabeleceu-se uma agricultura de subsistência. 
A fase da história paranaense denominada de tropeirismo teve importância na ocupação e estabelecimento de núcleos urbanos no Estado. Cabe, entretanto, ressaltar que se tratou de um povoamento de baixa densidade demográfica, embora tenha proporcionado a ocupação de amplas áreas geográficas, mais precisamente, os Campos Gerais, os Campos de Palmas e Guarapuava. Estes Campos faziam parte dos caminhos pelos quais passavam as tropas de bovinos e muares vindos do Rio Grande do Sul, que tinham como destino o mercado de Sorocaba. Neste mercado, os muares eram comercializados para servirem de apoio ao surto extrativista de ouro das Minas Gerais. Com o declínio do ciclo do ouro brasileiro, nos fins do século XVIII, a atividade tropeirista entrou em decadência.

A erva-mate, planta nativa do Paraná, teve seu ciclo baseado principalmente na demanda externa do Uruguai e da Argentina, apesar de haver um pequeno consumo interno. $\mathrm{O}$ dinamismo da exploração extrativista da erva-mate vigorou da época colonial até o início da Primeira Guerra Mundial. A exploração da erva-mate estendeu-se gradativamente por toda a região compreendida entre o Rio Paraná e Campo Mourão, inclusive a parte sul dos Campos Gerais.

Com relação ao ciclo da madeira, cabe ressaltar que esse produto, até o final do século XIX, era destinado apenas ao consumo interno. O surgimento de uma indústria extrativa, de peso na economia estadual, passou a existir quando esta começou a atender à demanda externa. Atualmente, a madeira ainda desempenha papel relativamente importante na economia do Estado.

Segundo Padis (1981), até o final do século XIX a ocupação do Paraná ocorreu em função de atividades econômicas definidas fora do seu território. $\mathrm{O}$ ciclo da mineração só ocorreu devido ao interesse europeu pelo metal precioso; no tropeirismo, o Paraná foi apenas utilizado como ponto de passagem obrigatória para tropas e rebanhos; a atividade ervateira era totalmente dependente do mercado internacional, tornando-se importante apenas quando o Paraguai, por questões de guerra 
e de relacionamento com importadores, foi praticamente eliminado do mercado; e, a atividade madeireira também era dependente do mercado externo.

Como resultado dos ciclos econômicos acima descritos, Konzen \& Zapparoli (1990, p. 160) concluem que a ocupação do Estado deu-se de forma extensiva e rarefeita, principalmente pela concessão pelo Estado de grandes extensões de terras devolutas a companhias particulares, exploradoras do mate e da madeira e colonizadoras do território.

Um novo impulso para a economia paranaense veio com 0 advento da cafeicultura. A princípio, essa atividade foi oriunda da expansão da cafeicultura paulista no final do século XIX.

A expansão da cafeicultura foi responsável, particularmente, pela ocupação da região Norte do Estado. A colonização desta região deu-se de forma dirigida, onde as concessões foram divididas em pequenas e médias propriedades, sendo raras as fazendas de 300 ou mais hectares.

Contudo, foram nas décadas de 40 e 50 do presente século que ocorreu a grande expansão da cafeicultura no Estado. De acordo com Magalhães Filho (1994, p.5) "A área plantada com café passa de 130 mil hectares em 1945 para 567 mil em 1955 e mais de um milhão em 1958”. Segundo Padis (1981) a produção, que chegava a 1,1 milhão de sacas na safra 1946/47, salta para 20,7 milhões na safra 1959/60 quando o Paraná ultrapassa São Paulo como maior produtor brasileiro.

Um dos impactos dessa expansão da cafeicultura no Paraná foi a grande quantidade de imigrantes nacionais que esta cultura atraiu. De acordo com os Censos Demográficos, a população rural do Paraná passou de 934 mil de habitantes em 1940 para 4,5 milhões de habitantes em 1960. 


\subsection{Transformações recentes na agropecuária paranaense}

As bases da atual estrutura produtiva do Paraná foram lançadas nos anos 70. Nesta década se acelera a modernização da agropecuária e um bom desempenho é observado na agroindústria.

\subsubsection{A evolução da agropecuária paranaense de 1970 a 1996}

$\mathrm{Na}$ década de 70 , a agropecuária paranaense passou por um processo de grandes transformações em sua base técnica. Estas implicaram mudanças em diversos aspectos de sua dinâmica e estrutura. Até a década de 60 o setor agropecuário apresentava um caráter tradicional, onde a quantidade de insumos industriais consumidos em seu processo produtivo não era significativa. Impulsionado pelo desenvolvimento da agroindústria, pelas políticas de incentivo às exportações, de crédito fácil e barato e pelos preços alcançados pelos principais produtos agrícolas exportáveis, o setor agropecuário, nos anos 70 , tomou impulso e acelerou seu processo de modernização.

A intensa modernização da agropecuária, entre 1970 e 1980, caracterizou-se como sendo um conjunto de mudanças na base técnica de produção e maior controle das condições do solo e do produto. Os indicadores mais comuns são o uso de tratores, adubos químicos, defensivos e de sementes selecionadas.

O número de tratores utilizados pelos produtores paranaenses aumentou em $339 \%$ entre 1970 e 1980 e entre 1985 e 1995 cresceu $29,09 \%$, segundo dados dos Censos agropecuários. A área cultivada por trator (ha/tratores) pode ser observada na Tabela 1. Verifica-se uma grande redução da relação área por trator entre 1970 e 1975, -62,10\%, passando de 785,52 ha/trator em 1970 para 297,74 ha/trator em 1975. Nos periodos subsequentes a relação área por trator teve variação de $-32,68 \%$ entre 1975 e $80,-17,79 \%$ entre 1980 e 85 e $-26,02 \%$ entre 1985 e 95 . Esses números indicam o uso crescente de mecanização na agropecuária paranaense, com destaque para a década de 70 . 
Tabela 1 Uso de tratores e adubos (químico e orgânico) na agropecuária do Paraná: $1970,75,80,85$ e 96 .

\begin{tabular}{|c|c|c|c|c|}
\hline \multirow[b]{2}{*}{ Anos } & \multicolumn{2}{|c|}{ Uso de tratores } & \multicolumn{2}{|c|}{ Uso de adubos } \\
\hline & ha/tratores & $\begin{array}{c}\text { Taxa de } \\
\text { crescimento (\%) }\end{array}$ & $\begin{array}{l}\% \text { de estab. que } \\
\text { usam adubo }\end{array}$ & $\begin{array}{c}\text { Taxa de } \\
\text { crescimento (\%) }\end{array}$ \\
\hline 1970 & 785,52 & - & 14,80 & - \\
\hline 1975 & 297,74 & $-62,10$ & 27,57 & 86,28 \\
\hline 1980 & 200,43 & $-32,68$ & 48,41 & 75,59 \\
\hline 1985 & 164,77 & $-17,79$ & 53,21 & 9,92 \\
\hline 1996 & 121,89 & $-26,02$ & 65,56 & 23,21 \\
\hline
\end{tabular}

Fonte: Censo Agropecuário do Paraná diversos anos.

Em relação a proporção de estabelecimentos que utilizavam adubos químico e orgânico, os maiores incrementos foram observados nos períodos de $1970 / 75,86,28 \%$, e $1975 / 80,75,59 \%$. Em 1980, a proporção de estabelecimentos que utilizavam adubos era mais que três vezes a observada em 1970. Em 1995 esta proporção era aproximadamente uma vez e meia maior que a observada em 1980. Evidencia-se, assim, a importância da década de 70 no processo de modernização da agropecuária paranaense.

As transformações na base produtiva agrícola implicaram alterações na estrutura fundiária, deixando à margem um grande número de pequenos proprietários rurais. A Figura 1 mostra a taxa de crescimento da área média (área total /número de estabelecimentos) dos estabelecimentos agropecuários no Paraná.

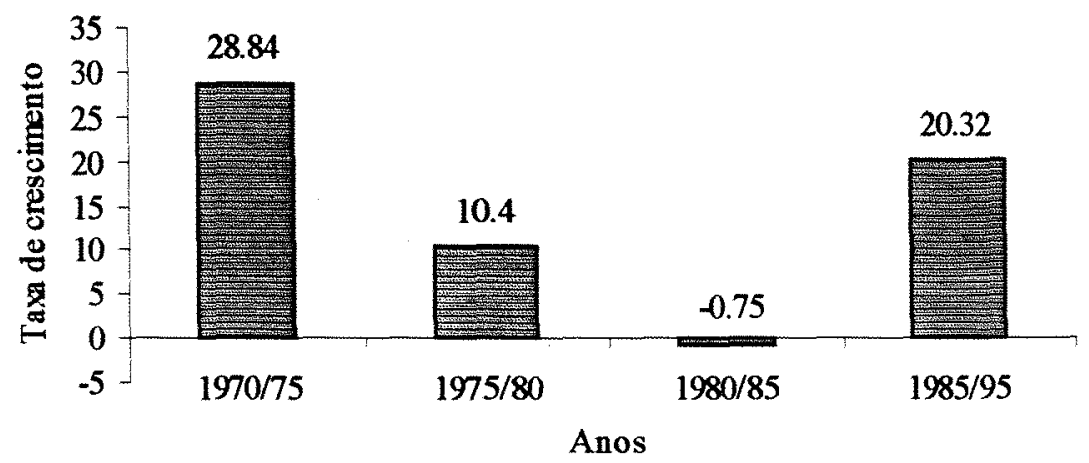

Figura 1 Taxa de crescimento da área média dos estabelecimentos agropecuários $\left(\mathrm{ha} / \mathrm{n}^{\circ} \mathrm{de}\right.$ estabelecimentos), Paraná, 1970-96. 
Verifica-se, de acordo com a Figura 1, que a área média dos estabelecimentos decresceu apenas no período compreendido entre 1980 e 1985; nos demais períodos cresceu, merecendo destaque os períodos 1970-75 e 1985-95.

Pode-se observar, no período de 1970 a 1980, que a área dos estabelecimentos agropecuários com até 10 ha foi a que mais diminuiu (ver Tabela 2). Levando-se em consideração a área dos estratos menores de 50 ha, a área foi reduzida em 893.602 ha. Os estratos de área situados entre 200 ha e 10.000 ha foram os que mais cresceram no periodo. Este fato encontra-se associado à modernização da agricultura, pois a escala de operação das unidades produtivas expandiram-se, tornando-se inviável a produção de culturas como a soja e o trigo em pequenas áreas.

Tabela 2 Variação absoluta (em ha) e percentual na área total dos estabelecimentos agropecuários, por grupos de área no Paraná, 1970-80, 1980-85 e 1985-95.

\begin{tabular}{lcccccc}
\hline Grupos de área & $\begin{array}{c}\text { Área } \\
\text { variação } \\
\text { absoluta } \\
1970-80\end{array}$ & $\begin{array}{c}\text { Variação } \\
\%\end{array}$ & $\begin{array}{c}\text { Área } \\
\text { variação } \\
\text { absoluta } \\
1980-85\end{array}$ & $\begin{array}{c}\text { Variação } \\
\%\end{array}$ & $\begin{array}{c}\text { Área } \\
\text { variação } \\
\text { absoluta } \\
1985-95\end{array}$ & $\begin{array}{c}\text { Variação } \\
\%\end{array}$ \\
\hline $0-10$ & -466.359 & $-29,61$ & 21.066 & 1,90 & -337.611 & $-29,88$ \\
$10-20$ & -284.752 & $-16,09$ & -26.237 & $-1,77$ & -225.052 & $-15,43$ \\
$20-50$ & -142.491 & $-5,15$ & -26.300 & $-1,00$ & -198.929 & $-7,66$ \\
$50-100$ & 197.970 & 12,68 & 28.271 & 1,61 & -13.939 & $-0,78$ \\
$100-200$ & 357.884 & 26,34 & 57.055 & 3,32 & 11.106 & 6,32 \\
$200-500$ & 599.255 & 33,81 & 157.794 & 6,65 & 329.194 & 13,02 \\
$500-1.000$ & 489.038 & 44,88 & 135.962 & 8,61 & 91.628 & 5,34 \\
$1.000-10.000$ & 778.821 & 33,94 & -58.970 & $-1,92$ & -216.379 & $-8,67$ \\
10.000 e mais & 225.433 & 51,51 & 291.892 & 4,51 & -248.247 & $-35,82$ \\
\hline Fonte: Censo Agropecuario do Parana, $1970,1980 \mathrm{e} 1985$ e $95 / 96$. & & &
\end{tabular}

No primeiro quinquênio da década de 80 a variação nas áreas dos estabelecimentos não se deu de forma tão intensiva quanto na década de 70 . Pode-se observar na Tabela 2 um incremento de área no estrato de 0 a 10 ha (de 21.066 ha), ao passo que os segmentos situados entre 10 e 50 ha continuaram tendo suas áreas reduzidas, somando -52.537 ha. Os estratos entre 50 e 1.000 ha tiveram suas áreas expandidas, mas, em dimensões menores que as observadas nos anos 70 . 
Os dados da Tabela 2, também, mostram que entre 1985 e 1995 as taxas de crescimento da área total dos extratos menores de 100 ha foram negativas, destacando-se os estratos de 0 a 10 ha $(-29,88 \%)$ e de 10 a 20 ha (-15,43\%). Os estratos de área que cresceram foram os maiores de 100 ha e menores de 1.000 ha, com destaque para os situados entre 200 e 500 ha, com uma expansão de 329.194 ha. Cabe ressaltar a queda na participação dos extratos de área superiores a 1.000 ha, onde os maiores de 10.000 ha apresentaram uma queda em sua área da ordem de $35,82 \%$.

De modo geral, o que se observou no período entre 1985 e 1995 foi o aumento da concentração de área nas propriedades de médio porte, e uma redução na área das pequenas propriedades e dos latifúndios. Este fato diferencia-se do processo de concentração observado nos anos 70 , pois, neste período os latifúndios também cresceram, cabendo redução, apenas, nas áreas das propriedades menores de 50 ha.

Cabe ressaltar que os médios produtores são os que sempre tiveram a área expandida. Isto se relaciona com o padrão tecnológico utilizado nas principais culturas que se expandiram no Paraná nos anos 70 , onde as propriedades de médio porte são compativeis com a escala das operações.

O processo de modernização da agropecuária paranaense pôde contar com um importante aliado, o Estado, via políticas institucionais. Entre essas, merece destaque a politica de crédito rural, a qual, segundo Pereira \& Lugnani (1991, p. 351), "criou vantagens artificiais em torno, principalmente, da soja e do trigo, retirando as vantagens comparativas dos demais produtos agrícolas paranaense". Os autores alicerçam esta afirmativa com base no volume de recursos e subsídios concedido a essas culturas.

A modernização e as politicas a ela aliadas fazem parte de um modelo de desenvolvimento agrícola brasileiro iniciado em meados da década de 60 . Este modelo atinge o ápice no final da década de 70, e inicia trajetória descendente no começo do anos 80 , juntamente com a crise financeira nacional e internacional. Como resultado, $o$ 
volume de subsídios e crédito destinado à agricultura foi reduzido. A Figura 2 mostra a decrescente participação do crédito rural na área cultivada no Estado ao longo das décadas de 80 e 90 .

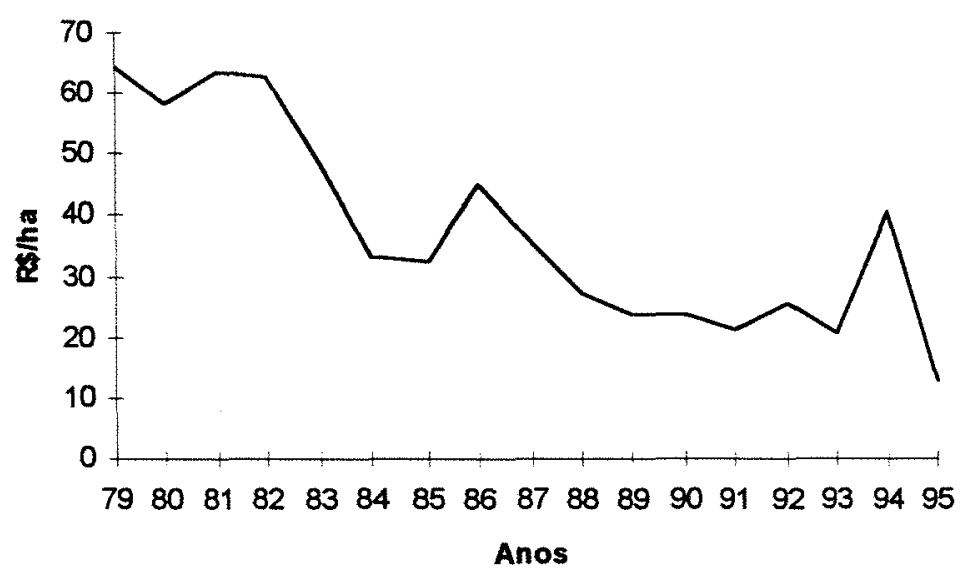

Figura 2- Volume de crédito rural por área (crédito/área) destinado à atividade agrícola no Paraná, 1979-95.

Fontes: Anuário Estatístico do Brasil (diversos anos)

Acompanhamento da Situação Agropecuária no Paraná (diversos meses)

Com a redução do volume de crédito por área cultivada no Estado, na década de 80 e nos anos 90, poder-se-ia esperar redução na produtividade das diversas culturas. Contudo, verificou-se o oposto, de acordo com os dados da Tabela 3. Das 14 culturas investigadas nos anos 80 e 90 apenas 4 apresentaram taxas anuais de crescimento negativas da produtividade da terra (algodão, café, cana e aveia), sendo que todas foram não significativas ao nível de $10 \%$. As demais culturas apresentaram taxas anuais de crescimento positivas.

Pode-se, então, deduzir que os agricultores devem estar utilizando formas alternativas para financiamento de suas safras, não contando apenas com os recursos advindos do Sistema Nacional de Crédito Rural. Há, também, a possibilidade de melhor utilização destes recursos, além dos ganhos advindos com a tecnologia. 
Tabela 3 Taxas anuais de crescimento ${ }^{1}$ da produtividade da terra ${ }^{2}$ nas principais atividades agrícolas do Paraná, 1970-79 e 1980-96.

\begin{tabular}{|c|c|c|c|c|}
\hline \multirow{2}{*}{ Produtos } & \multicolumn{2}{|c|}{$1970-79$} & \multicolumn{2}{|c|}{$1980-96$} \\
\hline & $\begin{array}{c}\text { Taxa de cres- } \\
\text { cimento } \%\end{array}$ & $\begin{array}{l}\text { Significância } \\
\text { a } 10 \%\end{array}$ & $\begin{array}{l}\text { Taxa de cres- } \\
\text { cimento } \%\end{array}$ & $\begin{array}{c}\text { Significância } \\
\text { a } 10 \%\end{array}$ \\
\hline Algodão & 0,23 & Não & $-0,98$ & Não \\
\hline Arroz & $-2,03$ & Não & 1,86 & Sim \\
\hline Café & $-5,92$ & Não & $-0,15$ & Não \\
\hline Cana & 0,05 & Não & $-0,21$ & Não \\
\hline Feijão & $-1,60$ & Não & 2,25 & Sim \\
\hline Mandioca & $-2,98$ & Sim & 1,24 & Sim \\
\hline Milho & 0,08 & Não & 2,03 & Sim \\
\hline Soja & 3,89 & Não & 1,10 & Não \\
\hline Trigo & $-1,06$ & Sim & 2,75 & Sim \\
\hline Laranja & & & 1,09 & Sim \\
\hline Sericicultura & $-1,70$ & Não & 0,92 & Sim \\
\hline Fumo & 0,63 & Não & 0,65 & Sim \\
\hline Aveia & 8,32 & Sim & $-1,53$ & Não \\
\hline Batata & 3,69 & Sim & 2,10 & Sim \\
\hline
\end{tabular}

Fontes: Anuário Estatístico do Brasil e Acompanhamento da Situação Agropecuária no Paraná.

Notas: (1) A taxa de crescimento anual ( $\beta$ ) foi estimada a partir da Função $Y_{i}=\alpha . e^{\beta . t} u_{i}, \quad$ onde: $Y_{i}=$ indice de produtividade anual dos principais produtos da agricultura paranaense, $t_{i}=$ tempo em ano, e $u_{i}$ é o erro associado.

(2) Obteve-se a produtividade dividindo-se a produção pela área dextinada ao cultivo de cada um dos produtos.

Sobre a pauta da produção agrícola no Paraná verifica-se, em 1970, de acordo com os dados da Tabela 4, que milho, café e feijão foram as atividades que mais ocuparam área no Estado. No primeiro qüinqüênio da década de 70 houve uma grande mudança na composição da pauta de produtos agricolas. As três culturas acima mencionadas perderam importância relativa frente ao binômio soja/trigo.

A soja detinha em 1970 apenas $5,65 \%$ da área ocupada pelas principais culturas no Paraná, passando este percentual para $22,88 \%$ em 1975 e $28,42 \%$ em 1980. De acordo com os dados do Anuário Estatístico do Brasil, a soja teve sua área cultivada aumentada em 2.167.602 ha entre 1970 e 1980, o que correspondeu a um incremento de $1.091 \%$ entre esses anos. Trigo, milho e cana-de-açúcar tiveram, também, suas áreas aumentadas em 560\%, 27\% e 42\%, respectivamente, entre 1970 e 1980. Como resultado, observa-se que culturas como arroz, café, algodão e feijão passaram a 
dar lugar às atividades mais ligadas ao complexo agroindustrial (soja, trigo e milho), que se vêm mantendo como as principais atividades agrícolas no Estado.

Tabela 4 Participação percentual da área destinada ao cultivo das principais atividades agrícolas no Paraná, 1970,75, 80, 85, 90 e 96.

\begin{tabular}{lrrrrrr}
\hline Anos & 1970 & 1975 & 1980 & 1985 & 1990 & 1996 \\
\hline Algodão & 8,30 & 3,74 & 3,96 & 6,71 & 6,48 & 2,43 \\
Arroz & 8,02 & 6,91 & 4,61 & 2,49 & 2,00 & 1,28 \\
Café & $\underline{19,46}$ & $\underline{14,45}$ & $\underline{8,66}$ & $\underline{5,27}$ & $\underline{5,64}$ & $\underline{1,78}$ \\
Cana-de-açúcar & 0,68 & 0,64 & 0,68 & 1,75 & 2,11 & 3,91 \\
Feijão & 14,67 & 10,77 & 9,61 & 8,99 & 7,28 & 7,81 \\
Mandioca & 1,64 & 1,40 & 0,53 & 1,07 & 1,35 & 1,60 \\
Milho & $\underline{34,96}$ & $\underline{26,96}$ & $\underline{25,43}$ & $\underline{28,99}$ & $\underline{27,49}$ & $\underline{32,48}$ \\
Soja & $\underline{5,65}$ & $\underline{22,88}$ & $\underline{28,42}$ & $\underline{27,29}$ & $\underline{29,97}$ & $\underline{31,81}$ \\
Trigo & $\underline{5,34}$ & $\underline{11,21}$ & $\underline{16,98}$ & $\underline{16,10}$ & $\underline{15,82}$ & $\underline{13,97}$ \\
Laranja & 0,12 & 0,09 & 0,05 & 0,06 & 0,06 & \\
Sericicultura & & & 0,13 & 0,21 & 0,49 & 0,57 \\
Furmo & 0,18 & 0,12 & 0,30 & 0,24 & 0,30 & 0,51 \\
Aveia & 0,05 & 0,13 & 0,09 & 0,29 & 0,42 & 1,12 \\
Batata & 0,80 & 0,59 & 0,50 & 0,48 & 0,55 & 0,65 \\
\hline Total & 100,00 & 100,00 & 100,00 & 100,00 & 100,00 & 100,00 \\
\hline
\end{tabular}

Fontes: Anuário Estatístico do Brasil (diversos anos) Acompanhamento da Situação Agropecuária no Paraná (diversos meses)

Segundo dados da Tabela 4 a soja, atividade que mais ocupou área na década de 70, mantém sua participação, em termos da área destinada ao seu cultivo, sem grandes oscilações nas décadas de 80 e 90 . Culturas como arroz e café têm suas participações reduzidas ao longo de todo o período 1970-96. Cana-de-açúcar, mandioca, milho, sericicultura e aveia têm suas participações aumentadas nas décadas de 80 e 90. A participação da área plantada com o algodão tem-se mantido instável, crescendo na década de 80, mas, voltando a decrescer ao longo dos anos 90 .

Em geral, após a década de 70, não se observou nenhuma mudança expressiva na pauta de produção na agricultura paranaense. O que se observa é a estrutura produtiva agrícola, no Estado, mantendo-se basicamente a mesma desde o final dos anos 70 , com as culturas de soja, trigo e milho sendo as principais na produção 
do Estado. Em 1980 estas três culturas ocupavam juntas 70,83\% da área agrícola no Paraná, passando em 1996 a ocupar 78,26\% desta.

\subsubsection{Rebanho de bovinos, suínos e aves no Paraná}

De acordo com Konzen \& Zapparoli (1990), a partir de 1950 acentuou-se o processo de criação de bovinos e suinos no Paraná. Como conseqüência, verificou-se também a ocupação da última fronteira agrícola do Estado, ou seja, das terras das regiões Noroeste, Oeste e Sudoeste. No Oeste e Sudoeste paranaense estabeleceram-se, principalmente, os colonos vindos de Santa Catarina e do Rio Grande do Sul.

Com relação à evolução do rebanho paranaense em períodos mais recentes, observa-se, de acordo com a Figura 3, que a avicultura atravessou um período de vigorosa expansão no Paraná a partir de 1981. França ${ }^{3}$, citada por Suzuki Junior (1995), aponta como fator responsável por esta expansão a elevação do consumo per capita do produto no País, de 2,3 kg/hab. em 1970 para $17 \mathrm{~kg} / \mathrm{hab}$. em 1994. Este aumento na demanda interna deveu-se, segundo a Conab (Companhia Nacional de Abastecimento), citada por Suzuki Junior (1995), à redução do preço do produto de R\$ 4,50/kg em 1974 para $\mathrm{R} \$ 1,25 / \mathrm{kg}$ em 1994.

De acordo com Nojima (1996), o setor avícola pôde também contar com o vigoroso aumento das vendas para o mercado externo, que passaram de US\$ 268 milhões em 1989 para US\$ 637 milhões em 1995. No Paraná, fato que também contribuiu bastante para a expansão da avicultura foi o estabelecimento da indústria integrada de abate de frangos.

Com relação ao rebanho bovino, verifica-se que os principais Estados criadores no Brasil em 1996 foram: Minas Gerais, com 14,02\% do rebanho

\footnotetext{
${ }^{3}$ FRANÇA, A. L.. Excesso de produção e redução do preço do frango. Gazeta Mercantil, São Paulo, 13 de set. 1995. P.11.
} 
nacional; Mato Grosso do Sul, 14,00\%; e, Goiás com 12,49\% do rebanho nacional. A participação do Paraná é de $6,24 \%$ no total do rebanho nacional, de acordo com Deus (1997). O consumo per capita de carne bovina em 1980 era de $32,4 \mathrm{~kg} / \mathrm{hab}$, decrescendo para 25,4 kg/hab. em 1995, segundo França, citada por Suzuki Junior (1995).

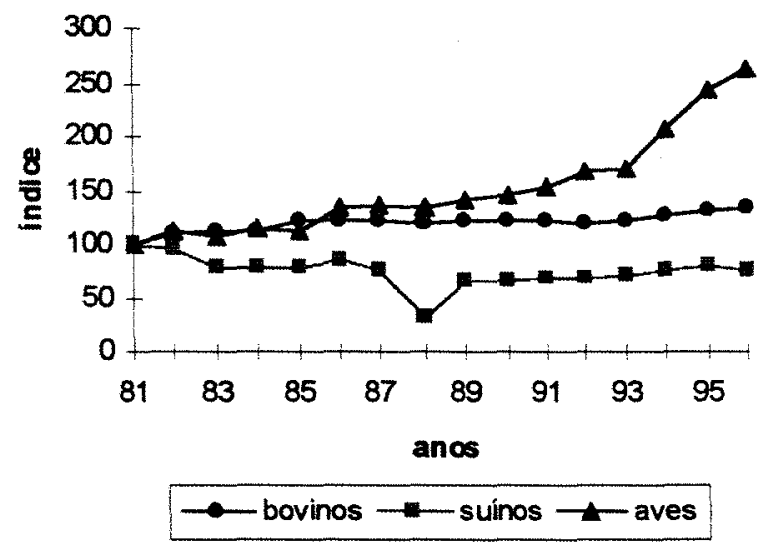

Figura 3 Índice de evolução do rebanho de bovinos, suínos e aves no Paraná, 1981-96. Fonte: Acompanhamento da Situação Agropecuária no Paraná.

Em 1996, o Paraná foi responsável por 11,07\% do rebanho de suínos no Brasil, sendo antecedido pelo Rio Grande do Sul, segundo Richter (1997). O rebanho de suínos no Paraná decresceu até 1988, recuperando-se parcialmente em 1989. Os quatro primeiros anos da década de 90 presenciaram uma estagnação desse rebanho (com pequeno aumento de 1990 para 1991), que voltou a crescer em 1994 e 1995 (ver Figura 3). $\mathrm{O}$ consumo per capita de carne suína tem-se mostrado ligeiramente declinante no Brasil nos anos 80 e 90, passando de $8,2 \mathrm{~kg} / \mathrm{hab}$. em 1980 para 7,9 kg/hab. em 1995, de acordo com França, citada por Suzuki Junior (1995). 


\subsection{A agroindústria paranaense}

O processo de expansão e modernização da agropecuária paranaense a partir da década de 70 esteve associado ao rápido crescimento dos setores industriais vinculados àquele setor, seja como fornecedor de insumos, máquinas e implementos, ou como processador de produtos agropecuários.

A partir do final da década de 60 e ao longo dos anos 70 , vê-se nascer um novo padrão industrial no Estado. Segundo IPARDES (1982), a indústria do Paraná não é mais aquela pequena indústria das décadas anteriores, voltada ao mercado local, dedicando-se apenas ao primeiro processamento de produtos agrícolas, pouco avançada tecnologicamente e, geralmente, com reduzida escala de produção. A nova indústria que surge nos anos 70 baseia-se em empresas de grande porte, voltadas para os mercados nacional e internacional, com tecnologia moderna e escalas de produção de grandes dimensões. É uma indústria competitiva e faz parte do aparelho industrial nacional.

$\mathrm{Na}$ indústria paranaense verifica-se que a agroindústria foi o seu eixo propulsor. De acordo com dados do Censo Industrial de 1985, os gêneros de maior importância na geração do valor da transformação industrial (VTI) na indústria paranaense foram a química (com $21,42 \%$ do VTI) e produtos alimentares (com 25,96\% do VTI). Juntos estes dois gêneros foram responsáveis por 47,38\% do VTI do Estado.

Os grupos industriais ligados ao setor agroindustrial dentro do gênero quimica (isto é, produção de óleos vegetais e fabricação de adubos, fertilizantes e corretivos do solo), foram responsáveis por $30 \%$ dos estabelecimentos, $46 \%$ do valor da produção e $45 \%$ do pessoal ocupado em 1980. Quando somados a estes dois grupos do gênero química o gênero produtos alimentares estima-se, a grosso modo ${ }^{4}$, que a agroindústria foi, em 1980, responsável por $27 \%$ dos estabelecimentos totais da indústria

\footnotetext{
${ }^{4}$ Há outras indústrias que pertencem à agroindústria, mas. que não foram consideradas. Portanto, os valores acima descritos subestimam a participação da agroindústria na indústria estadual.
} 
paranaense; por $37 \%$ do valor da produção industrial; e, por $20 \%$ do pessoal ocupado na indústria paranaense.

A agroindústria paranaense nos anos 80 incorporou novos ramos, como o processamento de carnes, açúcar e álcool, além de adaptar seus produtos de acordo com as exigências do mercado. Esta passou, também, a incorporar etapas produtivas com maior potencial de agregação de valor, reduzindo, assim, as exportações de produtos in natura.

A agroindústria encontra-se ligada à agricultura e à pecuária tanto ofertando produtos quanto processando a matéria-prima produzida por estas atividades. A agroindústria pode, então, ser dividida em dois grandes grupos de indústrias: as que recebem produtos da agricultura e da pecuária para serem processados, indústrias a jusante; e, as que produzem produtos para a agricultura e pecuária, indústrias a montante.

Os componentes da agroindústria do Paraná encontram-se descritos na Tabela 5, onde se verificam as taxas anuais de crescimento da produção de cada um deles. No caso da indústria de produtos derivados da agricultura, verifica-se que as empresas ligadas ao fumo foram as que apresentaram melhor desempenho no período $1981-93$, ou seja, cresceram a uma taxa de $8,3 \%$ a.a., seguidas do café $(4,45 \%$ a.a.), da cevada $(4,14 \%$ a.a.) e do milho $(3,67 \%$ a.a. $)$.

Dentro do grupo das indústrias produtoras de produtos utilizados pela agricultura, merece destaque a indústria de máquinas e equipamentos que teve uma taxa de negativa de crescimento de sua produção de 7,16\% a.a.. Este fato encontra-se relacionado à redução no crédito destinado à agricultura nos anos 80 e 90 e à grande demanda por bens de capital em períodos anteriores.

A agroindústria ligada à pecuária, de acordo com a Tabela 5 , cresceu sua produção à taxa de $1,53 \%$ a.a. no período de 1981 a 1993. A indústria de produtos 
utilizados pela pecuária apresentou melhor desempenho em relação à indústria de produtos derivados desta atividade. Na indústria de produtos derivados da pecuária, verificou-se um grande desempenho da indústria ligada à avicultura, com uma taxa de $6,56 \%$ de crescimento ao ano da produção.

Tabela 5 Taxa anual de crescimento da produção agroindustrial no Paraná, no periodo 1981-93.

\begin{tabular}{lcc}
\hline Ramos da agroindústria & Taxa de crescimento & Signif. a 10\% \\
\hline Produtos industriais derivados da agricultura & 1,66 & Sim \\
\hline Cana-de-açúcar & $-0,36$ & Não \\
Soja & $-1,68$ & Não \\
Trigo & 2,91 & Sim \\
Café & 4,45 & Sim \\
Fumo & 8,34 & Sim \\
Algodão & 2,03 & Sim \\
Milho & 3,67 & Sim \\
Cevada & 4,14 & Sim \\
Outros da agricultura & $-0,43$ & Não \\
Produtos industriais utilizados pela agricultura & 2,16 & Não \\
Máq. e equipamentos & $-7,16$ & Sim \\
Adubos e fertilizantes & 2,22 & Não \\
\hline Total da agricultura & 1,73 & Sim \\
\hline Produtos industriais derivados da pecuária & 1,37 & Sim \\
Bovinos & $-1,58$ & Não \\
Suínos & $-0,10$ & Não \\
Aves & 6,56 & Sim \\
Leite & 4,24 & Sim \\
Miúdos & $-7,06$ & Sim \\
Produtos industriais utilizados pela pecuária & $\underline{2,03}$ & Sim \\
\hline Total pecuária & 1,53 & Sim \\
\hline
\end{tabular}

Fonte: Estatísticas Básicas: Indicadores da produção agroindustrial 1981-93, séries retrospectivas, $\mathrm{n}^{\circ} 4$

Notas: (1) A taxa de crescimento anual $(\beta)$ foi estimada a partir da Função $Y_{i}=\alpha \cdot e^{\beta . t} . u_{i}$, onde: $Y_{i}=$ indice $(1981=100)$ dos grupos da agroindústria no Paraná e $t_{i}=$ tempo em ano.

Faz-se necessário verificar os fatores responsáveis pelo comportamento da indústria processadora de soja no Paraná. Sua produção decresceu no período de 1981 a 1993 a uma taxa de $1,68 \%$ a.a., mas, esta taxa foi não significativa ao nível de $10 \%$. Um dos fatores que pode ser considerado para explicar este comportamento encontra-se relacionado à intensa expansão desta indústria nos anos 70. Segundo Pereira (1995), a indústria produtora de óleos vegetais em bruto cresceu 306,8\% entre 1970 e 1975 e $71,1 \%$ entre 1975 e 1980 . A isto soma-se o fato de em periodos mais recentes o aumento 
da produção de grãos no Brasil estar dirigindo-se principalmente para as regiões do cerrado do Mato Grosso, Minas Gerais, Pará, Tocantins, Piauí e Maranhão, além das áreas de alta fertilidade na Bahia.

Juntamente com o deslocamento da produção de grãos para estas novas fronteiras, verifica-se, de acordo com a Tabela 6 , que as empresas processadoras de grãos também estão se deslocando para estas Regiões. Pode-se verificar na Tabela 6 que apenas a participação do Sul do Brasil na quantidade de soja em grãos processada tem caído; as participações das demais regiões têm aumentado.

Tabela 6 Participação das regiões Nordeste, Sudeste, Sul e Centro-Oeste na quantidade de soja em grãos processada do Brasil, safras 92/93-95/96.

\begin{tabular}{ccccc}
\hline Safra & Nordeste & Sudeste & Sul & Centro-Oeste \\
\hline $92 / 93$ & 3,08 & 13,67 & 63,99 & 19,26 \\
$93 / 94$ & 3,28 & 14,65 & 59,82 & 22,25 \\
$94 / 95$ & 3,60 & 13,45 & 57,98 & 24,96 \\
$95 / 96$ & 3,75 & 14,42 & 59,89 & 21,94 \\
\hline
\end{tabular}

Fonte: Anuário Estatistico do Brasil. 


\section{ASPECTOS METODOLÓGICOS E FONTES DE DADOS}

Este capítulo compõe-se de três itens. Inicialmente (item 4.1), discutem-se as diferenças metodológicas entre as fontes de informações sobre pessoal ocupado na agropecuária. Em seguida, são revisados modelos existentes sobre determinação de salários na agricultura (item 4.2). Por fim (item 4.3), especifica-se o modelo de determinação de salários rurais a ser utilizado.

\subsection{Fontes de informações sobre pessoal ocupado}

A questão do emprego no setor agropecuário paranaense foi tratada através da análise de sua evolução, composição e especialização. Para tanto, foram coletados e analisados os dados referentes ao pessoal ocupado na agropecuária paranaense no periodo de 1970 a 1996.

O quadro 1 mostra as principais fontes de dados sobre o pessoal ocupado nas atividades rurais, verificando-se, em cada uma delas, como são divididas quanto à amplitude e periodicidade.

Tratam-se de informações distintas que devem ser utilizadas de modo separado. Assim, para analisar a evolução e a composição do pessoal ocupado na agropecuária paranaense nas décadas de 80 e 90 (primeiro objetivo especifico deste trabalho) faz-se uso dos Censos Demográficos para avaliar a distribuição da população segundo sua residência urbana ou rural. 
Quadro 1- Informacoes referentes às fontes dados sobre o pessoal ocupado na agropecuária paranaense.

\begin{tabular}{|c|c|c|c|c|}
\hline & \multicolumn{2}{|c|}{ Pesquisa Nacional por Amostra de Domicílio - PNAD } & \multirow[t]{2}{*}{ Censo Agropecuário } & \multirow[t]{2}{*}{ Censo Demográfico } \\
\hline & Dados agrupados & Microdados & & \\
\hline Tipo de informaçăo & $\begin{array}{l}\text { Pessoas ocupadas que tinham trabalho } \\
\text { durante toda ou parte da semana de } \\
\text { referencia, ainda que năo houvesse } \\
\text { exercido atividade nesse periodo por } \\
\text { motivo de férias, licença, greve, etc. }\end{array}$ & $\begin{array}{l}\text { Trata-se da ocupaça que a pessoa } \\
\text { exercia na semana de referencia. }\end{array}$ & $\begin{array}{l}\text { Pessoal ocupado abrange todas as pessoas, } \\
\text { com e sem remuneraçăo, que na data do } \\
\text { Censo encontravam-se executando } \\
\text { serviços ligados as atividades do } \\
\text { estabelecimento, exceto os que } \\
\text { desempenhavam trabalhos por conta de } \\
\text { empreiteiros. }\end{array}$ & $\begin{array}{l}\text { Pessoas de } 10 \text { anos ou mais que trabalharam nos anos de } \\
\text { referencia. }\end{array}$ \\
\hline $\begin{array}{l}\text { Divisăo das infor- } \\
\text { maç̄os }\end{array}$ & $\begin{array}{l}\text { Pessoas ocupadas na atividade agricola } \\
\text { encontram-se divididas em : } \\
\text { - empregados } \\
\text { - conta-própria } \\
\text { - empregadores } \\
\text { - não remunerados } \\
\text { - sem remuneraça }\end{array}$ & $\begin{array}{l}\text {-tipos de ocupaçăo encontradas nos } \\
\text { empreendimentos; } \\
\text {-ocupaça na semana de referencia } \\
\text { - forma de contrataçăo do trabalho }\end{array}$ & $\begin{array}{l}\text { Informaçōes para as seguintes atividades } \\
\text { econômicas: agricultura, pecuária, } \\
\text { horticultura e floricultura, silvicultura, } \\
\text { avicultura, cunicult./ apicult./ silv. e } \\
\text { extraçåo vegetal. As pessoas ocupadas } \\
\text { encontram-se divididas em: } \\
\text { - Responsável e membros nåo } \\
\text { remunerados da familia; } \\
\text { - empregados em trabalho permanente; } \\
\text { - empregados temporários; } \\
\text { - outra condiçăo; }\end{array}$ & 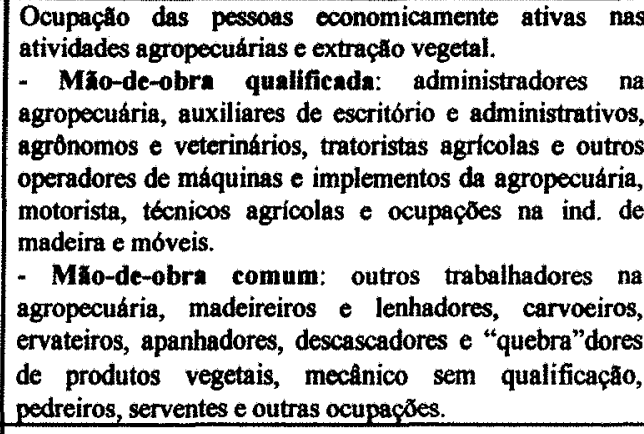 \\
\hline Periodicidade & 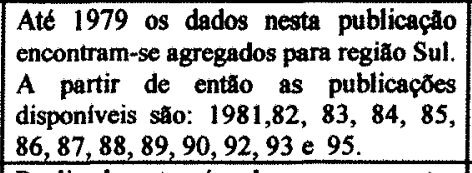 & $92,93,95$ e 96 & $\begin{array}{l}\text { No periodo em análise estão disponíveis: } \\
1970,1975,1980,1985 \text { e } 95 / 96 \text {. }\end{array}$ & $\begin{array}{l}\text { No periodo que nos interessa estăo disponiveis: } 1970 \text {, } \\
1980 \text { e } 1991 \text {. }\end{array}$ \\
\hline Amplitude & $\begin{array}{l}\text { Realizada através de uma amostra } \\
\text { probabilistica de domicilios. Para } \\
\text { expansă da amostra utilizam-se } \\
\text { estimadores que consideram o } \\
\text { crescimento populacional ocorrido entre } \\
\text { os dois últimos anos demográficos. } \\
\text { Estes dados abrangem a população } \\
\text { residente nas unidades domiciliares. }\end{array}$ & Mesma metodologia da PNAD & $\begin{array}{l}\text { Para coleta dos dados do Censo } \\
\text { Agropecúário săo aplicados questionários } \\
\text { nos estabelecimentos agropecuários. As } \\
\text { informaçes stao obtidas diretamente dos } \\
\text { responsáveis pelos estabelecimentos. }\end{array}$ & $\begin{array}{l}\text { Investigadas todas as pessoas em alguns quesitos }{ }^{1} \text {. Outros } \\
\text { quesitos, mais complexos, foram investigados por } \\
\text { amostragem. A expanssa da amostra é feita atraves de } \\
\text { estimadores, utilizando pesos atribuidos às pessoas de um } \\
\text { mesmo extrato. }\end{array}$ \\
\hline
\end{tabular}

conjugal, nacionalidade, migraçőes internas, frequéncia d̀ escola, nivel de instruçăo, cursos concluídos, movimentos pendulares, fecundidade e mortalidade foram investigados por amostragem. 
Os dados dos Censos Agropecuários permitem uma avaliação do total de pessoas ocupadas na agropecuária segundo o tipo de atividade e a posição na ocupação. Contudo, tais dados não permitem avaliar a especialização e a qualificação da mão-de-obra. Isto é feito utilizando os dados das PNADs e dos Censos Demográficos. Os resultados dessas análises estão no capítulo 5 .

No que se refere aos dados da PNAD são necessárias algumas observações adicionais. Segundo Silva (1996a), os dados das PNADs de 1992 e 1993 não são comparáveis com os da PNAD de 1990 devido à mudança no critério de enumeração das pessoas ocupadas, que passaram a incluir: a) pessoas que declararam trabalhar mais de 1 hora (antes era de mais de 15 horas por semana); e, b) trabalhadores na produção para o próprio consumo e na construção para o próprio uso, que anteriormente não eram consideradas.

$A$ inclusão do item $b$ na PNAD deu-se em função de críticas como a de Corrêa (1995, p.19), onde a autora chama atenção para o fato de que quando se considera a produção para autoconsumo ${ }^{5}$, tende-se “ (...) a subestimar a renda nos estratos mais baixos, em dado momento no tempo, e pode implicar uma super estimação do nível de desigualdade dos rendimentos do setor agrícola".

Grossi (1996) verifica que houve um "superdimencionamento" da população paranaense nas PNADs até 1990, devido a pesquisa ser amostral e basear-se em projeção da população censitária de 1980. A PNAD de 1990 estima uma população de 9,1 milhões de pessoas no Paraná, enquanto o Censo Demográfico de 1991 corrigiu para 8,4 milhões de pessoas. Na zona rural esta diferença atinge 630 mil pessoas.

Ressalta-se, ainda, que o levantamento da PNAD é feito tomando-se como unidade de amostragem os domicilios. Com isto, temos a força de trabalho, isto é, a quantidade de trabalhadores possíveis de serem utilizados. Metodologia

\footnotetext{
${ }^{5}$ Muitas vezes a produção para o autoconsumo é parte importante da renda real dos pequenos produtores rurais.
} 
diferente é empregada nos Censos Agropecuários, onde as perguntas são feitas aos produtores agropecuários. Com isto tem-se, no Censo Agropecuário, o total de pessoas ocupadas.

\subsection{Revisão de alguns modelos utilizados para determinação dos salários no setor agropecuário}

Inicialmente, é necessário distinguir os modelos que explicam o comportamento dos rendimentos dos trabalhadores em todas as fontes de rendimento da ocupação principal, dos modelos que procuraram estimar equações de determinação dos salários da mão-de-obra ocupada no setor agropecuário brasileiro.

Como exemplo do primeiro tipo de modelo tem-se o trabalho de Balsadi (1996). E como exemplos de modelos de determinação de salários rurais têm-se os trabalhos de Gasques (1975), Cunha \& Maia (1984), Bacha (1988).

Balsadi (1996) procurou averiguar quais eram os principais condicionantes do rendimento das pessoas ocupadas na agricultura paulista em 1981 e 1990. Considerou, para tanto, as seguintes variáveis: situação de domicilio, sexo, idade, posição na ocupação ${ }^{6}$, escolaridade e carteira assinada.

O procedimento que Balsadi (1996) utilizou foi o de estimar duas equações para determinação da renda. A primeira objetivava analisar a importância relativa dos condicionantes da renda de todas as pessoas ocupadas. Já a segunda, com o intuito de captar o efeito do registro em carteira sobre o rendimento das pessoas ocupadas na agricultura paulista, incluiu somente as categorias empregado e trabalhador volante. A fonte de dados utilizada pelo autor foram as PNADs de 1981 e 1990.

\footnotetext{
${ }^{6}$ Contém quatro categorias: empregados (incluindo parceiro empregado); trabalhador volante (com ou sem intermediário); conta própria (inclui parceiro conta-própria); e, empregador (inclui parceiro empregador)
} 
Gasques (1975) objetivou estudar alguns aspectos do mercado de trabalho não qualificado em São Paulo. Para tanto, estimou equações de oferta e demanda de trabalho volante, para o estado de São Paulo, no período de 1964 a 1970. Gasques (1975) trabalhou com as seguintes variáveis: quantidade de mão-de-obra volante em São Paulo; salário da mão-de-obra volante; salário diário da mão-de-obra diarista residente; salário mínimo oficial vigente na capital do Estado; relação preço recebido/preços pagos (indica índice de paridade ou relação de trocas); preço dos tratores em São Paulo; índice de produtividade agrícola em São Paulo, usado como proxy da tecnologia; e, variáveis binárias para os meses de março, junho e novembro (a presença dessas variáveis procura captar os efeitos das variações estacionais de uso de mão-deobra sobre a variável dependente nos diferentes períodos do ano).

Gasques (1975) apenas considerou os trabalhadores temporários (volantes), nada dizendo sobre a determinação da remuneração dos assalariados permanentes.

Cunha \& Maia (1984) estimaram duas equações para verificar o efeito da mudança de tecnologia sobre a taxa de crescimento das duas categorias de trabalhadores ocupados na atividade agrícola: mão-de-obra permanente e temporária. Esses autores reconheceram que essas duas categorias de trabalhadores têm qualificações diferentes e, portanto, geravam curvas de oferta e demanda distintas.

As variáveis utilizadas no modelo de Cunha \& Maia (1984) foram: total de mão-de-obra permanente e temporária; preço do capital; preço da terra; nível de produção; composição da produção; índice tecnológico; salário do trabalhador permanente e uma variável que capta a taxa de salário urbano e a probabilidade de conseguir emprego fora da agricultura. O período analisado foi a década de 70 . $\mathrm{O}$ trabalho foi feito para 74 microrregiões dos seguintes Estados: Espírito Santo, Rio de Janeiro, Paraná, Santa Catarina, Mato Grosso e Mato Grosso do Sul. 
O avanço no trabalho de Cunha \& Maia (1984), em relação à literatura até então existente, foi no sentido de reconhecer que as duas categorias de trabalhadores, temporários e permanentes, têm qualificações diferentes que geram curvas de oferta e de demanda distintas. Contudo, Bacha (1988) considerou que a limitação do modelo de Cunha \& Maia (1984) encontrava-se no fato de os autores considerarem que a mão-de-obra permanente substitui a mão-de-obra temporária, não ocorrendo o inverso.

O avanço do trabalho de Bacha (1988) em relação ao trabalho de Cunha \& Maia (1984) encontra-se no fato de considerar que a mão-de-obra temporária suplementa a permanente e não a substitui ou a complementa? ${ }^{7}$.

A explicação de Bacha (1988, p.242) para o fato de a mão-deobra temporária suplementar o trabalho de trabalhadores permanentes é a seguinte: “ (...) o aumento de produtividade eleva o uso de mão-de-obra na época de colheita, e a mecanização e o uso de outros insumos modernos diminui o uso de mão-de-obra nas etapas de plantio e tratos culturais. Desse modo, tornou-se mais lucrativo, porque implica menores custos, o uso de um número mínimo de trabalhadores assalariados permanentes suplementados pelos trabalhadores assalariados temporários nos momentos de demanda de mão-de-obra acima da capacidade de ser oferecida pelos primeiros".

\subsection{Descrição do modelo econométrico de determinação do salário rural a ser utilizado}

Para verificar o comportamento dos salários na agropecuária paranaense, no período de 1977 a 1996, utiliza-se o modelo desenvolvido por Bacha (1988). Trata-se de um modelo geral feito para determinação dos salários na cafeicultura de Minas Gerais, o qual pretende-se adaptar para a realidade da agropecuária paranaense.

\footnotetext{
${ }^{7}$ Segundo Ferreira (1994/95) suplementar significa suprir ou compensar a deficiência e complementar tem o significado de servir de complemento. A diferença encontra-se no fato de que uma é utilizada para complementar e a outra (suplementar) é utilizada para suprir a mão-de-obra em períodos de aumento de demanda.
} 
Em seu modelo, Bacha (1988, p. 254) considerou "a segmentação da oferta de trabalhadores rurais entre permanentes e temporários, sendo estes compostos de pequenos produtores não-tecnificados, bóia-frias permanentes, bóiafrias esporádicos e bóia-frias temporários". No diagrama 1 pode-se ter uma idéia melhor sobre quais são os componentes da mão-de-obra assalariada na agropecuária.

Cabe, entretanto, esclarecer que a categoria de pequenos proprietários tecnificados não faz parte da mão-de-obra assalariada empregada na agropecuária brasileira. Trata-se, apenas, de uma segmentação de pequenos proprietários. 
Diagrama 1 Componentes da mão-de-obra na agricultura

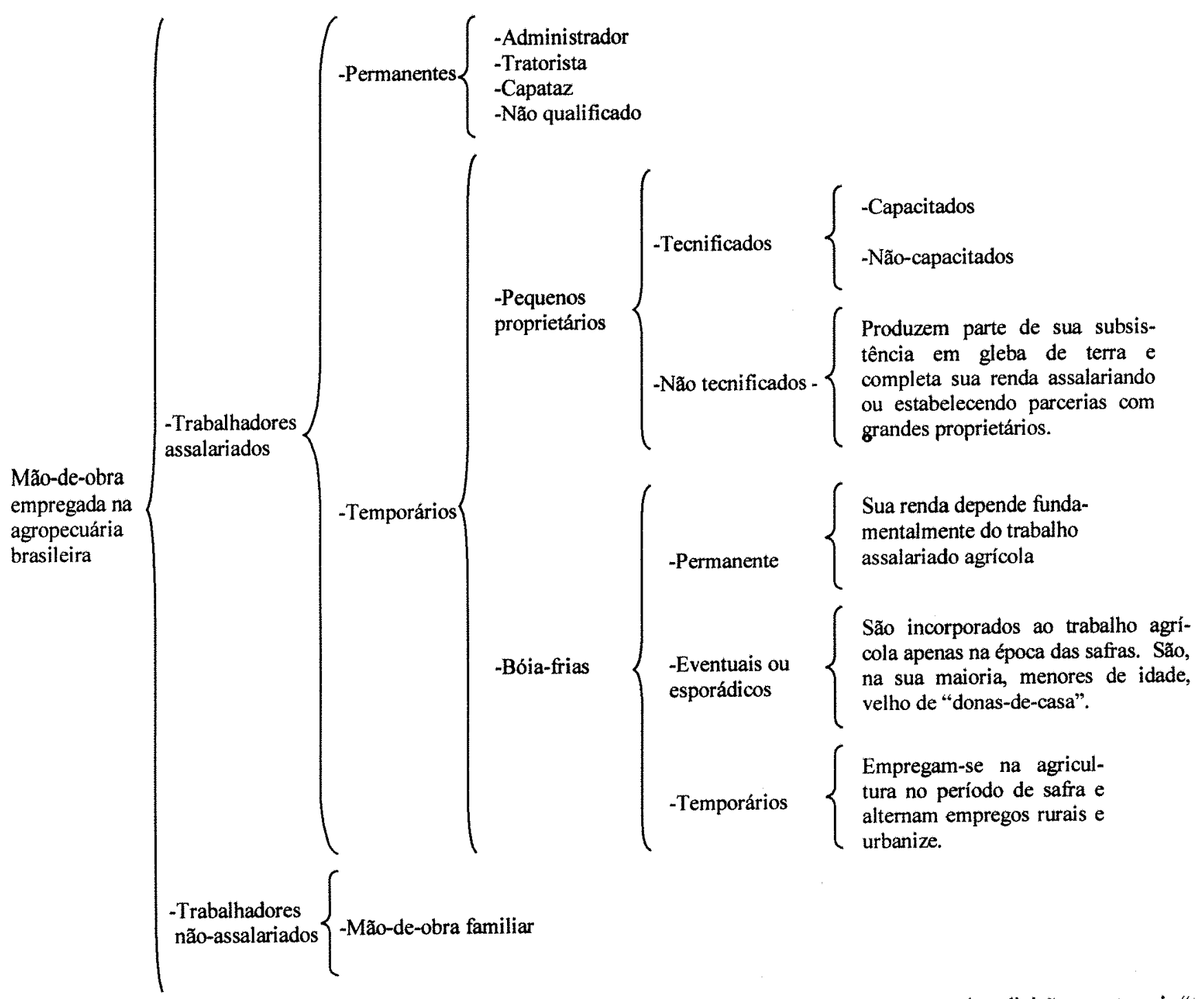

Fonte: Baseado na composição da mão-de-obra da agricultura feita por (Bacha,1988, p.248-254), acrescentando a divisão na categoria "trabalhador assalariado permanente" 
O salário rural é estabelecido, a cada momento, pelo cruzamento da curva da demanda de mão-de-obra rural assalariada com a sua curva de oferta (ver Figura 4).

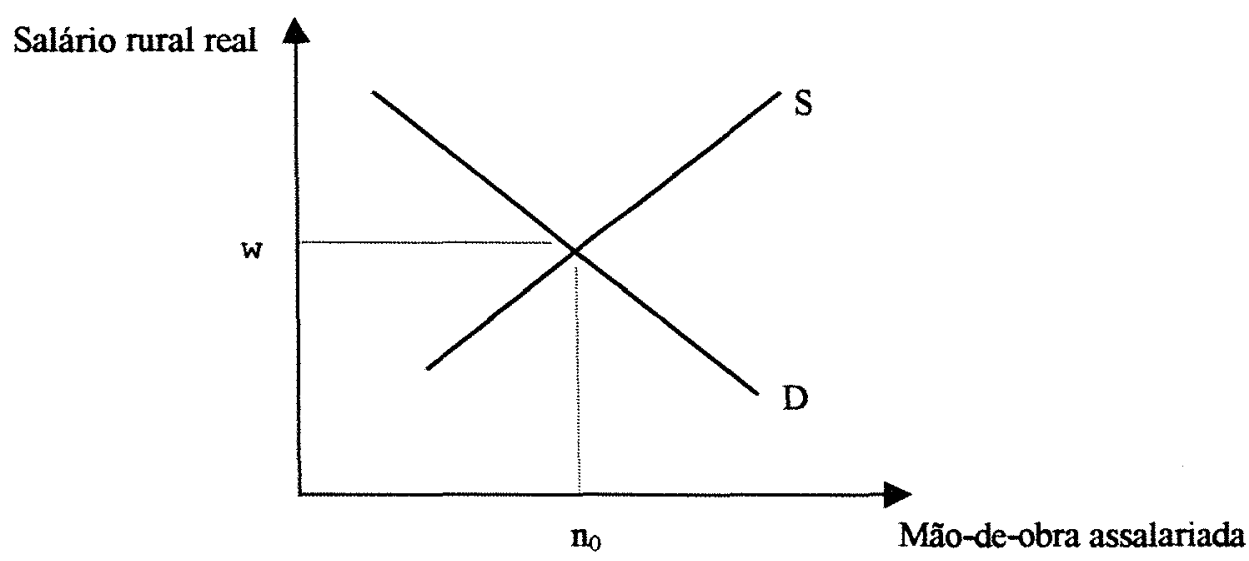

Figura 4- Determinação do salário rural

A curva de demanda por mão-de-obra assalariada é considerada ser negativamente inclinada e passível de ser deslocada. Sua inclinação é justificada pela suposição de que "os proprietários agrícolas maximizam lucros diante de uma função de produção com rendimentos marginais decrescentes de mão-de-obra" (Bacha, 1988, p. 269). Portanto, a demanda por fatores de produção é derivada do mercado de produtos.

Os deslocamentos da curva de demanda de mão-de-obra são atribuídos a fatores que geram fortes aumentos na utilização de mão-de-obra assalariada, como, por exemplo, a expansão da produção, implicando assim em aumentos nos salários.

A curva de oferta é positivamente inclinada, pois os trabalhadores rurais somente oferecerão mais mão-de-obra quanto maior forem os salários oferecidos. 


\subsubsection{Modelo econométrico para determinação do salário do trabalhador temporário}

\section{a) Oferta de mão-de-obra temporária}

Bacha (1988) fez algumas considerações sobre a oferta de mãode-obra temporária. Com relação à oferta de mão-de-obra dos pequenos produtores não tecnificados, Bacha considerou que esta depende dos ganhos alternativos dos mesmos nas suas propriedades. "Quando aumentam os preços recebidos pelos seus produtos eles só oferecerão a mesma quantidade de mão-de-obra de antes a um salário maior. Assim, a curva de oferta de mão-de-obra, em termos de salário real, desloca-se para a esquerda"(Bacha, 1988, p. 272).

Conforme demostrado no Diagrama 1, os bóia-frias foram decompostos em: permanentes; eventuais ou esporádicos; e, temporários. Segundo Bacha (1988), a oferta da mão-de-obra bóia-fria temporário dependerá das possibilidades de emprego e salário no setor urbano, pois, esta categoria alterna empregos rurais e urbanos. Porém, no presente trabalho optou-se por excluir a variável que quantifica o volume de emprego alternativo urbano. Com as crises de emprego urbano nas décadas de 80 e 90 as poucas oportunidades de emprego nas cidades não funcionam mais como grande fator de atração.

A oferta de mão-de-obra das demais categorias é determinada pelos seguintes fatores: "Os 'bóia-frias eventuais ou esporádicos' participam apenas temporariamente do mercado de trabalho e não pertencem ao mercado de trabalho urbano. Sua oferta de trabalho depende do salário rural do volante. Para Bacha (1988, p.273) os 'bóia-frias permanentes' são mais influenciados pelo salário mínimo legal (onde este último vigora) e pelo ganho real do trabalhador assalariado permanente, além do salário real do volante". Porém, optou-se por excluir a variável salário do trabalhador permanente na determinação do salário do bóia-fria permanente, pois, acredita-se que o 
salário mínimo por si só seja capaz de representar as correções a serem feitas no rendimento do bóia-fria permanente.

Do exposto acima, a oferta de trabalho temporário é a seguinte:

$$
L T T=L p+L b t+L b p+L b e
$$

onde:

$L T T=$ oferta de trabalho temporário;

$L p=$ oferta de trabalho do pequeno produtor não tecnificado;

$L b t=$ oferta de trabalho do "bóia-fria temporário";

$L b p=$ oferta de trabalho do "bóia-fria permanente";

$L b e=$ oferta de trabalho do "bóia-fria esporádico".

De acordo com as adaptações feitas, tem-se as seguintes funções de comportamento:

$$
\begin{aligned}
& L p=f_{1}(W V, P a) \\
& L b t=f_{2}(W V, W U) \\
& L b e=f_{3}(W V) \\
& L b p=f_{4}(W V, W M)
\end{aligned}
$$

onde:

$W V=$ salário real do trabalhador temporário;

$P a=$ preço real dos produtos agrícolas recebidos pelos pequenos produtores não tecnificados;

$W U=$ salário real do emprego urbano alternativo;

$W M=$ salário mínimo real;

Considerando que as equações (2), (3), (4) e (5) tenham formas lineares, encontram-se: 


$$
\begin{array}{ll}
L p=a_{0}+a_{1} . W V+a_{2} \cdot P a & \text { onde: } a_{1}>0 \text { e } a_{2}<0 \\
L b t=b_{0}+b_{1} \cdot W V+b_{2} \cdot W U & \text { onde: } b_{1}>0 \text { e } b_{2}<0 \\
L b e=c_{0}+c_{1} \cdot W V & \text { onde: } c_{1}>0 \\
L b p=d_{0}+d_{1} \cdot W V+d_{2} \cdot W M & \text { onde: } d_{1}>0 \text { e } d_{2}<0
\end{array}
$$

A oferta total de trabalho temporário é dada pela equação (1). Substituindo (2a), (3a), (4a) e (5a) em (1), tem-se:

$$
L T T=A_{0}+A_{I} \cdot W V+A_{2} \cdot P a+A_{3} \cdot W U+A_{4} \cdot W M
$$

onde:

$$
\begin{array}{ll}
A_{0}=a_{0}+b_{0}+c_{0}+d_{0} & \\
A_{1}=a_{1}+b_{1}+c_{1}+d_{1} & A_{1}>0 \\
A_{2}=a_{2} & A_{2}<0 \\
A_{3}=b_{2} & A_{3}<0 \\
A_{4}=d_{2} & A_{4}<0
\end{array}
$$

\section{b) Demanda de mão-de-obra temporária}

Bacha $(1988$, p.276) ressaltou que ocorre "demanda de mão-deobra temporária até o limite onde o preço do produto vezes a produtividade física marginal do trabalho temporário é igual ao seu salário. Desse modo, a demanda de trabalho temporário depende de seu salário (WV), do volume da produção do produto comercial $(\mathrm{P})$, do custo dos insumos (r), do preço real do produto comercial $(\mathrm{Pe})$ e do nível tecnológico (Ye)".

Para aplicar este modelo ao caso do Paraná, optou-se por considerar na função de demanda por mão-de-obra temporária a variável produtividade da mão-de-obra agrícola (PMO) como medida do nível tecnológico. Optou-se, também, por substituir as variáveis $\mathrm{r}$ e Pe pelo índice de paridade $(\pi=\mathrm{Pe} / \mathrm{r})$ que os produtores 
rurais paranaenses obtiveram. Ficando assim definida a função demanda por mão-de-obra temporária:

$D T T=g(W V, P, \pi, P M O)$

Considerando que a expressão (7) tem forma linear, encontramos:

$D T T=B_{0}+B_{1} \cdot W V+B_{2} \cdot P+B_{3} \cdot \pi+B_{4} \cdot P M O$

onde: $B_{1}<0, B_{2}>0, B_{3}>0$ e $B_{4}>0$

Com relação ao sinal esperado do coeficiente da variável PMO, espera-se que o mesmo seja positivo, pois, o aumento da produtividade da mão-de-obra, permanecendo as outras variáveis constantes (como o salário da mão-de-obra), leva a redução do custo de produção. Isto leva os agricultores a desejar produzir mais, o que, por sua vez, deverá implicar maior demanda por mão-de-obra

A condição de equilíbrio implica:

$D T T=L T T$

As equações (6), (7a) e (8) formam um sistema simultâneo onde WV, LTT e DTT são variáveis endógenas e Pa, WU, WM, P, $\pi$ e PMO são variáveis exógenas.

Substituindo em (8) as expressões (6) e (7a), tem-se:

$B_{0}+B_{1} \cdot W V+B_{2} \cdot P+B_{3} \cdot \pi+B_{4} \cdot P M O=A_{0}+A_{1} \cdot W V+A_{2} \cdot P a+A_{3} \cdot W U+A_{4} \cdot W M$

Isolando WV, tem-se:

$\left(B_{1}-A_{1}\right) \cdot W V=A_{0}+A_{2} \cdot P a+A_{3} \cdot W U+A_{4} \cdot W M-B_{0}-B_{2} \cdot P-B_{3} \cdot \pi-B_{4} \cdot P M O$ 


$$
\begin{array}{r}
W V=\left[\left(A_{0}-B_{0}\right) /\left(B_{1}-A_{1}\right)\right]+\left[A_{2} \cdot /\left(B_{1}-A_{1}\right)\right] \cdot P a+\left[A_{3} \cdot /\left(B_{1}-A_{1}\right)\right] \cdot W U+\left[A_{4} \cdot /\left(B_{1}-A_{1}\right)\right] \cdot \\
\quad W M+\left[-B_{2} \cdot /\left(B_{1}-A_{1}\right)\right] \cdot P+\left[-B_{3} \cdot /\left(B_{1}-A_{1}\right)\right] \cdot \pi+\left[-B_{4} \cdot\left(B_{1}-A_{1}\right)\right] \cdot P M O
\end{array}
$$

ou

$$
W V=C_{0}+C_{1} \cdot P a+C_{2} \cdot W U+C_{3} \cdot W M+C_{4} \cdot P+C_{5} \cdot \pi+C_{6} \cdot P M O
$$

onde:

$$
\begin{array}{ll}
C_{0}=\left[\left(A_{0}-B_{0}\right) /\left(B_{1}-A_{1}\right)\right] & C_{1}=\left[A_{2} /\left(B_{1}-A_{1}\right)\right] \\
C_{2}=\left[A_{3} /\left(B_{1}-A_{1}\right)\right] & C_{3}=\left[A_{4} /\left(B_{1}-A_{1}\right)\right] \\
C_{4}=\left[-B_{2} /\left(B_{1}-A_{1}\right)\right] & C_{5}=\left[-B_{3} /\left(B_{1}-A_{1}\right)\right] \\
C_{6}=\left[-B_{4} /\left(B_{1}-A_{1}\right)\right] &
\end{array}
$$

$$
\text { Espera-se: } \mathrm{C}_{1}>0 ; \mathrm{C}_{2}>0 ; \mathrm{C}_{3}>0 ; \mathrm{C}_{4}>0 ; \mathrm{C}_{5}>0 ; \mathrm{e}, \mathrm{C}_{6}>0
$$

\subsubsection{Modelo econométrico de determinação do salário do trabalhador permanente}

\section{a) Oferta de mão-de-obra permanente}

Considera-se que a oferta de mão-de-obra permanente depende do seu salário e do salário mínimo real, tomado como referência. A função (11) expressa a oferta da mão-de-obra permanente.

$L T P=h(W T P, W M)$

onde:

$L T P=$ oferta de trabalhadores permanentes;

$W T P=$ salário real do trabalhador permanente;

$W M=$ salário mínimo real.

Em termos lineares a expressão (11) torna-se:

$$
L T P=c_{0}+c_{1} \cdot W T P+c_{2} \cdot W M \quad \text { onde: } c_{1}>0 \text { e } c_{2}<0
$$


Considera-se que quanto maior for WTP, maior será a oferta de trabalho. A posição dessa curva é afetada por WM. Um aumento de WM leva os trabalhadores agrícolas permanentes a desejarem maior WTP para a mesma quantidade ofertada de trabalho. Portanto, o aumento de WM desloca a curva de oferta de trabalho dos trabalhadores permanentes para a esquerda.

A equação de demanda de trabalhadores permanentes é dada por:

$D T P=l(W T P, P, \pi, P M O)$

onde:

$D T P=$ demanda de trabalhadores permanentes;

$P=$ volume da produção do produto comercial;

$\pi=$ relação entre preços recebidos e preços pagos; $\mathrm{e}$,

$P M O=$ produtividade da mão-de-obra.

A equação (12) difere da de Bacha (1988) por considerar a relação entre preços recebidos e preços pagos, ao invés dessas duas variáveis de modo separado. Bacha (1988) também tinha incluído uma variável que media a efetividade da legislação trabalhista no campo. Exclui-se no presente trabalho esta variável por considerar que em períodos mais recentes os impactos dessa legislação não são idênticos aos de quando fora instituída. E, por fim, considerou-se a produtividade da mão-de-obra como uma proxy do nível tecnológico.

Em termos lineares a expressão (12) torna-se:

$D T P=D_{0}+D_{1} \cdot W T P+D_{2} \cdot P+D_{3} \cdot \pi+D_{4} \cdot P M O$

onde: $\mathrm{D}_{1}<0, \mathrm{D}_{2}>0, \mathrm{D}_{3}>0, \mathrm{D}_{4}>0$ 
A condição de equilíbrio no mercado de trabalho é dada por:

$L T P=D T P$

As equações (11a), (12a) e (13) formam um sistema simultâneo onde as variáveis endógenas são: LTP, DTP e WTP e as variáveis exógenas são: WM, P, $\pi$, e PMO.

Substituindo em (13) as expressões (11a) e (12a), tem-se:

$c_{0}+c_{1} \cdot W T P+c_{2} \cdot W M=D_{0}+D_{1} \cdot W T P+D_{2} \cdot P+D_{3} \cdot \pi+D_{4} \cdot P M O$

Isolando WTP em um dos membros, temos:

$\left(c_{1}-D 1\right) \cdot W T P=D_{0}-c_{0}-c_{2} \cdot W M+D_{2} \cdot P+D_{3} \cdot \pi+D_{4} \cdot P M O$

$W T P=\left[\left(D_{0}-c_{0}\right) /\left(c_{l}-D_{l}\right)\right]+\left[c_{2} /\left(c_{l}-D_{l}\right)\right] \cdot W M+\left[D_{2} /\left(c_{l}-D_{l}\right)\right] \cdot P+\left[D_{3} /\right.$ $\left./\left(c_{1}-D_{1}\right)\right] \cdot \pi+\left[D_{4} /\left(c_{1}-D_{1}\right)\right] \cdot P M O$

ou:

$W T P=Y_{0}+Y_{1} \cdot W M+Y_{2} \cdot P+Y_{3} \cdot \pi+Y_{4} \cdot P M O$

onde:

$Y_{0}=\left[\left(D_{0}-c_{0}\right) /\left(c_{l}-D_{1}\right)\right]$

$Y_{1}=\left[-c_{2} /\left(c_{l}-D_{1}\right)\right]$

$Y_{2}=\left[D_{2} /\left(c_{1}-D_{1}\right)\right]$ $Y_{3}=\left[D_{3} /\left(c_{1}-D_{1}\right)\right]$

$Y_{4}=\left[D_{4} /\left(c_{1}-D_{1}\right)\right]$

Espera-se: $\mathrm{Y}_{1}>0 ; \mathrm{Y}_{2}>0 ; \mathrm{Y}_{3}>0 ; \mathrm{e}, \mathrm{Y}_{4}>0$

\subsubsection{Definição das variáveis utilizadas no modelo e as fontes dos dados}

As equações (10) e (14), abaixo repetidas, foram estimadas para determinar o comportamento dos salários dos trabalhadores temporário e do trabalhador permanente, respectivamente, no setor agropecuário do Paraná entre 1977 e 1996.

$W V=C_{0}+C_{1} \cdot P a+C_{2} \cdot W U+C_{3} \cdot W M+C_{4} \cdot P+C_{5} \cdot \pi+C_{6} \cdot P M O$ 
$W T P=Y_{0}+Y_{1} \cdot W M+Y_{2} \cdot P+Y_{3} \cdot \pi+Y_{4} \cdot P M O$

onde:

$W V$ = salário do trabalhador temporário no Paraná (obtido junto à Secretaria do Estado da Agricultura e do Abastecimento/ Departamento de Economia Rural);

$W T P=$ salário dos trabalhadores permanentes (obtido junto a Secretaria do Estado da Agricultura e do Abastecimento/ Departamento de Economia Rural);

$P a=$ preço dos produtos produzidos pelos pequenos produtores no Paraná. Considerouse o indice de preço recebido pelos produtores no Paraná (dado coletado na Revista Conjuntura Econômica);

$W U=$ salário real do emprego urbano alternativo. Considerou-se como proxy o salário do servente geral na indústria da construção civil em São Paulo (dado coletado na revista Construção de São Paulo);

$W M=$ salário mínimo real mensal (dado coletado no Anuário Estatístico do Brasil);

$P=$ volume total da produção agrícola paranaense (Dados coletados no Anuário Estatístico do Brasil e no Acompanhamento da situação agropecuária no Paraná) ;

$\pi=$ índice da relação entre os preços recebidos e preços pagos pelos produtores rurais do Paraná ${ }^{8}$ (dado coletado na Revista Conjuntura Econômica);

$P M O=$ produtividade da mão-de-obra. Foi utilizada como proxy a produtividade da mão-de-obra da agricultura brasileira calculada por Gasques \& Conceição (1997)

\footnotetext{
${ }^{8}$ Houve uma mudança metodológica na construção dos índices em 1986, pois a série a partir deste ano passou a ser não compativel com a anterior. Optou-se. então, por fazer uma média entre os anos $1986 \mathrm{e}$ 1987 e manter a série inteira da mesma fonte. por achar que a perda seria maior se a série fosse construida com base em fontes diferentes.
} 
Todas as variáveis que estavam em valores correntes foram corrigidas de acordo com o IGP-DI da FGV com base em agosto de 1994=100.

${ }^{9}$ Com base na estimativa da taxa anual de crescimento da produtividade da mão-de-obra no periodo 1977 a 1994 foram feitas as estimativas da produtividade da mão-de-obra para os anos de 1995 e 1996. 


\section{COMPORTAMENTO DO PESSOAL OCUPADO NA AGROPECUÁRIA DO PARANÁ}

Este capitulo articula as informações das fontes de dados citadas no item 4.1 do capítulo 4 , procurando analisar a evolução, especialização e participação de cada categoria de trabalhadores rurais no total do pessoal ocupado nas atividades econômicas da zona rural no Paraná.

\subsection{População rural no Paraná}

Podem ser observados dois movimentos distintos no Paraná sobre o comportamento da população rural. O primeiro vai até o final da década de 60 , quando o Estado tornou-se grande receptor de mão-de-obra; e, o outro ocorreu nas décadas posteriores, quando o Estado passou a perder população rural.

Em 1940, segundo dados da Tabela 7, a população rural do Paraná era de 934 mil habitantes e representava $75,57 \%$ da população total. Em 1970 esta população saltou para 4.450 mil habitantes, implicando crescimento de $376,45 \%$ em relação a 1940. O principal fator responsável pelas altas taxas de crescimento da população rural até fins da década de 60 foi a expansão da cafeicultura, principalmente na Região Norte Novo, onde era encontrada a maior parte de suas plantações.

Ainda de acordo com os dados da Tabela 7, no decorrer dos anos 70 esta situação reverteu-se, quando a maior parcela da população do Estado passa a situar-se nas cidades, atingindo $58,93 \%$ da população total em 1980 . A população rural 
sofreu um decréscimo de 28,47\% entre 1970 e 1980. Em 1991 a zona rural do Paraná contava com pouco mais de $1 / 4$ da população total, reafirmando, assim, o processo de urbanização do Estado também nos anos 80 . E esse processo continuou na década de 90 , com a população rural representando $22,12 \%$ da população total do Paraná em 1996.

Tabela 7 População total, rural e urbana no Paraná em valores absolutos e participação percentual, 1940, 50,60,70, 80, 91 e 96 (valores absolutos em milhares).

\begin{tabular}{|c|c|c|c|c|c|}
\hline \multirow[b]{2}{*}{ Anos } & \multirow{2}{*}{$\begin{array}{c}\text { Total } \\
\text { Absoluto }\end{array}$} & \multicolumn{2}{|c|}{ Rural } & \multicolumn{2}{|c|}{ Urbana } \\
\hline & & Absoluto & $\%$ & Absoluto & $\%$ \\
\hline 1940 & 1.236 & 934 & 75,57 & 302 & 24,43 \\
\hline 1950 & 2.115 & 1.587 & 75,04 & 528 & 24,96 \\
\hline 1960 & 4.296 & 2.968 & 69,10 & 1.327 & 30,90 \\
\hline 1970 & 9.668 & 4.450 & 63,60 & 2.547 & 36,40 \\
\hline 1980 & 7.750 & 3.183 & 41,07 & 4.567 & 58,93 \\
\hline 1991 & 8.443 & 2.250 & 26,65 & 6.193 & 73,35 \\
\hline 1996 & 9.004 & 1.992 & 22,12 & 7.012 & 77,88 \\
\hline
\end{tabular}

Fonte: Contagem da População, 1996.

Cabe, entretanto, ressaltar que a redução da população rural foi cinco vezes maior que a diminuição do pessoal ocupado na zona rural ${ }^{10}$ entre os anos de 1970 e 1980 e 5,4 vezes entre 1980 e 1991, segundo dados do Censo Demográfico do Paraná de 1970, 1980 e 1991.

Alves (1997), em estudo realizado para o Brasil e suas regiões, destaca dois motivos para o êxodo rural:

1- força de atração da cidade: condições melhores de emprego e vida nas cidades considerando-se os salários, a infra-estrutura social (escolas, assistência médica, etc.) e os programas de governo que são mais vantajosos que os oferecidos no meio rural; e,

\footnotetext{
${ }^{10}$ Consideraram-se pessoas ocupadas de 10 anos ou mais na agricultura, pecuária, silvicultura, extração vegetal, caça e pesca.
} 
2- força de expulsão do campo: a falta de infra-estrutura social no campo, a legislação trabalhista ${ }^{11}$, a falta de oportunidades para adquirir terras e crédito subsidiado para mecanização.

Segundo Alves (1997, p.19), estas duas forças atuaram juntas no periodo 1950-85, provocando êxodo rural no Brasil e regiões. Após 1985, o autor ressalta que o êxodo persistiu muito mais em função da força de expulsão. Segundo o autor: "Com o amadurecimento do mercado de trabalho agrícola, maior fiscalização do governo e a escalada de conflitos trabalhistas na justiça, os agricultores aceleram a substituição de mão-de-obra por máquinas e equipamentos".

No caso do Paraná, em decorrência da modificação na função de produção agricola, observou-se uma redução na demanda por mão-de-obra. Istake $(1995)^{12}$ estimou as funções de produção para o Estado em 1970 e 1985 . As estimativas dos parâmetros resultaram nas seguintes funções:

para 1970

$V P_{i}=1,97 \cdot P O_{i}^{0,41} \cdot V B_{i}{ }^{0,48}$

para 1985

$V P_{i}=0,08 \cdot P O_{i}^{0,35} \cdot V B_{i}{ }^{0,76}$

Onde:

$i$ = Índice correspondente a observação de uma dada microrregião;

${ }^{11}$ No que se refere a legislação, Alves (1997) chama atenção para o fato de a legislação complicar a administração dos trabalhadores e encarecer o custo da mão-de-obra, tendo enorme efeito no desenvolvimento da mecanização.

${ }^{12}$ ISTAKE, M. (da Universidade Estadual de Maringá, Maringá, Pr). Estimativa da função de produção (Cobb Douglas) agrícola para o Paraná- 1970 e 1985 (em elaboração). 
$V P=$ Valor da produção ${ }^{13}(\mathrm{Cr} \$ 1.000 \mathrm{em} 1970$ e CZ\$ $1.000 \mathrm{em} 1985)$

$P O=$ Abrange as pessoas com ou sem remuneração que na data do Censo prestavam serviços ligados às atividades dos estabelecimentos rurais; $\mathrm{e}$,

$V B=$ Valor dos bens (utilizado como proxy do capital), considerando os bens existentes em 31 de dezembro dos anos 1970 e 1985. Incluindo terras, prédios, culturas plantadas, etc.

Nas funções (15) e (16) os expoentes das variáveis trabalho (PO) e capital (VB) representam as elasticidades da produção em relação a estas variáveis. Analisando estes coeficientes, verifica-se que a importância do capital junto ao processo produtivo em 1970 já era superior à da mão-de-obra, mas, esta diferença acentua-se em 1985, mostrando a maior participação do capital no processo produtivo em detrimento da mão-de-obra.

A maior participação do capital em relação à mão-de-obra na função de produção encontra-se relacionada à substituição da cafeicultura com elevado coeficiente de utilização de mão-de-obra pelo binômio soja/trigo, cujos coeficientes de ocupação de trabalho por hectare de terra são bastante modestos em relação aos da cafeicultura $^{14}$.

\subsection{Evolução e composição do pessoal ocupado na atividade agropecuária paranaense segundo os dados dos Censos Agropecuários}

No Paraná vem ocorrendo, há mais de duas décadas, juntamente com a redução da população rural, queda na participação da atividade agropecuária na geração de empregos frente aos demais setores. Em 1981, segundo dados da PNAD,

${ }^{13}$ O Censo de 1985 foi publicado em 1988 e os valores monetários foram expressos em CZ\$ apesar de em 1985 ter vigorado o Cr\$.

${ }^{14}$ Segundo pesquisa de campo realizada pela Secretaria de Estado da Agricultura e Abastecimento do Paraná/ Departamento de Economia Rural (SEAB/DERAL) estes coeficientes que indicam a 
$47,58 \%$ das pessoas ocupadas encontravam-se na atividade agropecuária, $15,44 \%$ no setor industrial e 36,98\% no terciário; em 1995 estes percentuais foram 30,81\%, 18,93\% e 50,26\%, respectivamente. A inversão da posição dos setores agropecuário e terciário na geração de ocupação ocorreu em meados da década de 80 .

Com relação às atividades econômicas desenvolvidas na zona rural do Paraná, verifica-se na Tabela 8 que a agricultura foi a principal atividade a empregar, tanto em 1970 (85,15\% do pessoal ocupado na agropecuária) quanto em 1980 (78,87\% do pessoal ocupado na agropecuária). A pecuária é a segunda atividade rural a empregar no Paraná, 10,29\% em 1970 e 14,89 \% em 1980 do pessoal ocupado na agropecuária. Em 1995 a participação da agricultura no total de pessoal ocupado caiu para $58,79 \%$ e a participação da pecuária e da agropecuária foram $21,18 \%$ e $16,44 \%$, respectivamente.

Tabela 8 Taxa de crescimento $^{1}$ e participação do pessoal ocupado agropecuária paranaense, 1970-95, segundo as classes de atividade econômica.

\begin{tabular}{|c|c|c|c|c|c|c|c|}
\hline \multirow[t]{2}{*}{ Atividades } & \multicolumn{4}{|c|}{ Taxa de crescimento } & \multicolumn{3}{|c|}{ Participação (\%) } \\
\hline & $1970-75$ & $1975-80$ & $1980-85$ & $1985-95$ & 1970 & 1980 & 1995 \\
\hline Agricultura ${ }^{2}$ & 9,76 & $-23,01$ & $-0,01$ & $-46,91$ & 85,15 & 78,87 & 58,79 \\
\hline Pecuária & $-13,97$ & 53,38 & 17,89 & $-14,02$ & 10,29 & 14,89 & 21,18 \\
\hline Horticultura & 103,25 & 35,04 & 32,92 & 138,27 & 0,13 & 0,38 & 1,71 \\
\hline Silvicultura & $-30,27$ & 74,65 & 20,17 & 49,55 & 0,49 & 0,65 & 1,64 \\
\hline Agropecuária ${ }^{3}$ & $-65,20$ & 164,38 & $-26,33$ & 406,36 & 3,11 & 3,14 & 16,44 \\
\hline Outros $^{4}$ & 173,95 & 176,51 & 25,29 & $-93,39$ & 0,83 & 2,07 & 0,24 \\
\hline Total & 4,93 & $-13,05$ & 2,61 & $-30,59$ & 100,00 & 100,00 & 100,00 \\
\hline
\end{tabular}

Fonte: Censo Agropecuário do Paraná, 1970, 1980, 1985 e 1995.

Nota: (1) Taxa de crescimento no período $=\left(\frac{y_{t 2}}{y_{t 1}}-1\right) \cdot 100$, onde: $\mathrm{y}_{\mathrm{t} 1}=$ pessoal ocupado na atividade no periodo 1 e $y_{12}=$ pessoal ocupado na atividade no periodo 2 .

(2) Para o ano de 1995 considerou-se pessoal ocupado em lavouras temporárias e permanentes.

(3) Produção mista lavoura e pecuária.

(4) Neste item nos anos 1970-85 encontram-se as seguintes classes de atividade econômica: avicultura, cunicultura, apicultura, sericicultura e extração vegetal. Para o ano 1995 considerou-se a pesca e aquicultura e a produção de carvão vegetal.

quantidade de mão-de-obra ( $\mathrm{h} / \mathrm{dia}$ ) são os seguintes: para o café adensado na implantação é 164,86 , no $2^{\circ}$ ano é 104,00 e no terceiro ano é 388,16 ; para a soja este coeficiente é 3,71 e para o trigo é 0,77 . 
Apesar de ser a principal atividade na geração de empregos no setor rural, observa-se uma tendência de redução de pessoas ocupadas no subsetor agricultura no período de 1975 a 1995. A taxa de crescimento do pessoal ocupado nesse subsetor foi positiva apenas no periodo entre 1970 e 1975. Após este período esta tem sido negativa, de acordo com a Tabela 8 . Os períodos que apresentaram as maiores quedas no volume de pessoal ocupado no subsetor agricultura foram entre 1975 e 1980, $-23,01 \%$, e mais recentemente 1985 a $1995,-46,91 \%$.

Essa redução do pessoal ocupado no subsetor agricultura simultaneamente à expansão na produção agrícola ocorre por duas razões: mudança na pauta agrícola e crescimento da produtividade do trabalho. Foi ressaltado no item 3.2.1 do capítulo 3 que a produção agrícola no Paraná vêm-se especializando nas culturas de soja, milho e trigo, que demandam menos trabalho que culturas anteriormente mais importantes no Estado, como a cafeicultura. Além disso, a produção agrícola vêm utilizando cada vez mais força mecânica (a relação ha/trator caiu $59 \%$ entre 1975 e 1995), o que eleva a produtividade do trabalho e implica substituição de trabalho por capital.

A pecuária aumentou o número de pessoas ocupadas em suas atividades no período 1975/80 e 1980/85, de acordo com a Tabela 8 . No início dos anos 70 e nos anos compreendidos entre 1985 e 1995 ocorreram taxas de crescimento negativas do pessoal ocupado nesse subsetor $(-13,97 \%$ entre $1970 / 75$, e $-14,02 \%$ entre 1985 e 1995). A horticultura merece destaque, pois ao longo dos 25 anos aqui analisados tem aumentado o volume de mão-de-obra ocupada. A silvicultura tem apresentado taxas de crescimento positivas no número de pessoas ocupadas a partir de 1975. A agropecuária, entre 1985 e 1995, foi a atividade que apresentou maior taxa de crescimento no volume de emprego no setor agropecuário, $406,36 \%$.

$\mathrm{Na}$ Tabela 8 verifica-se que o volume total de empregos gerados nas atividades rurais paranaense decresceu consideravelmente entre 1985 e 1995, - 
$30,59 \%$, superando o decréscimo observado entre 1975 e 1980, -13,05\%, onde ocorreu uma grande expansão no processo de modernização da agropecuária.

No que se refere à participação por sexo do pessoal ocupado na agropecuária paranaense observa-se, segundo dados dos Censos Agropecuários, que a mulher teve uma participação média de $33 \%$ neste mercado de trabalho, entre 1970 e 1985.

Com relação às categorias de pessoal ocupado na agropecuária paranaense observa-se, de acordo com a Tabela 9, que a maior parcela do pessoal ocupado, 86\% em 1970 e $76 \%$ em 1995, refere-se à mão-de-obra familiar. Esta encontrase classificada no Censo Agropecuário como responsável e membros não remunerados da familia. Fazem parte desta categoria o produtor ou o administrador responsável pelo estabelecimento recenseado, recebendo quantia fixa ou cota-parte da produção, e os membros de sua família que o ajudavam na execução dos trabalhos sem receber qualquer tipo de remuneração.

Tabela 9 Taxa de crescimento ${ }^{1}$ e participação percentual das diversas categorias no pessoal ocupado na agropecuária, Paraná, 1970, 75, 80, 85 e 95.

\begin{tabular}{|c|c|c|c|c|c|c|c|}
\hline \multirow{2}{*}{ Categorias } & \multicolumn{4}{|c|}{ taxa de crescimento } & \multicolumn{3}{|c|}{ Participação (\%) } \\
\hline & $1970-75$ & $1975-80$ & $1980-85$ & $1985-95$ & 1970 & 1985 & 1995 \\
\hline Mão-de-obra familiar & $-1,31$ & $-18,21$ & 0,42 & $-28,48$ & 85,61 & 74,12 & 76,36 \\
\hline Empregados permanentes & 35,59 & 7,88 & $-13,14$ & $-14,70$ & 6,67 & 9,05 & 11,12 \\
\hline Empregados temporários & 35,87 & 17,69 & 33,56 & $-53,34$ & 6,01 & 13,71 & 9,22 \\
\hline Parceiros & 133,89 & $-12,96$ & $-25,14$ & $-51,03$ & 1,24 & 2,02 & 1,43 \\
\hline Outra condição & $-29,14$ & $-27,26$ & 321,45 & 18,36 & 0,47 & 1,10 & 1,87 \\
\hline Estab. s/ pessoal ocup. & $-17,23$ & $-7,52$ & 1,98 & $-20,78$ & & & \\
\hline Total & 4,93 & $-13,05$ & 2,61 & $-30,59$ & 100,00 & 100,00 & 100,00 \\
\hline \multicolumn{8}{|c|}{ Fonte: Censo Agropecuário do Paraná, 1970, 1980, 1985 e 1995.} \\
\hline
\end{tabular}

1 e $y_{\mathfrak{L}}=$ pessoal ocupado na atividade no período 2 . 
Ainda de acordo com a Tabela 9, verifica-se que os empregados temporários e permanentes têm sua participação aumentada. Os trabalhadores permanentes passaram de $6,67 \%$ do total de pessoas ocupadas em 1970 para $9,05 \%$ em 1985 e 11,12\% em 1995. Essas percentagens para os trabalhadores temporários foram $6,01 \%, 13,71 \%$ e 9,22 , respectivamente. ${ }^{15}$

A maior queda no emprego na agropecuária do Paraná é registrada no período 1985 a 1995, como observado anteriormente. Segundo dados da Tabela 9, as categorias que apresentaram maiores reduções relativas no número de pessoas ocupadas foram os empregados temporários $(-53,34 \%)$ e os parceiros $(-51,03$ \%). A única categoria que apresentou taxa de crescimento positiva no decênio foi os classificados como "outra condição", onde são consideradas todas as pessoas cujo regime de trabalho diferencia do pessoal dos demais grupos, tais como: agregados, moradores, etc. A mão-de-obra familiar decresceu $28,48 \%$ e o número de empregados permanentes decresceu $14,70 \%$.

\subsection{Evolução e composição do pessoal ocupado na atividade agropecuária paranaense segundo os dados das PNADs}

Neste item analisa-se a evolução do pessoal ocupado na agropecuária com os dados das PNADs. Procura-se observar, com dados anuais, possíveis alterações de comportamento que não podem ser observados com os dados qüinqüenais ou decenais dos Censos Agropecuários. Além disso, os dados das PNADs permitem analisar a distribuição do pessoal ocupado por tipo de atividades rurais no Paraná em maior nível de desagregação que os Censos Agropecuários.

\footnotetext{
${ }^{15}$ Não obstante. no período de 1980 a 1985 o número de empregados permanentes decresceu $13,14 \%$. enquanto o número de empregados temporários cresceu ao longo de todo o período 1970-85, como se pode observar na Tabela 9.
} 
Contudo, para efeito de análise dos dados publicados nas PNADs, faz-se necessário ressaltar os seguintes aspectos, já discutidos no capítulo 4 do presente trabalho:

a) houve "super dimensionamento" da população paranaense pelas PNADs até 1990, devido à pesquisa amostral basear-se em projeções da população censitária de 1980; e,

b) em 1992 e 1993 o IBGE ampliou o conceito de população economicamente ativa, incorporando pessoas que trabalhavam menos de 15 horas semanais, além de incorporar duas novas categorias.

Assim a série de dados das PNADs foi dividida em duas (ver Tabelas 10 e 11).

No período compreendido entre 1981 e 1990 o nível de emprego na agropecuária teve uma taxa de crescimento de $-1,50 \%$ a. a., de acordo com a Tabela 10 , onde apenas os por conta própria tiveram taxa de crescimento positiva, $0,91 \%$ ao ano. A categoria que mais teve redução foi a dos sem remuneração, $-3,01 \%$ a.a.; seguida dos empregadores, $-2,68 \%$ a. a. (mas esta taxa foi não significativa ao nível de $10 \%$ ), e dos empregados, $-1,65 \%$ ao ano.

Tabela 10 Categorias de pessoas ocupadas que tinham trabalho na semana de referência na atividade agropecuária no Paraná, 1981-90.

\begin{tabular}{lccccc}
\hline Anos $^{1}$ & Empregado & Empregador & Cont. própria & Sem remun. & Total \\
\hline 1981 & 467.249 & 56.798 & 387.688 & 626.379 & 1.538 .114 \\
1982 & 430.674 & 47.089 & 387.633 & 669.221 & 1.524 .617 \\
1983 & 461.580 & 41.674 & 376.840 & 635.686 & 1.515 .780 \\
1984 & 426.791 & 31.544 & 389.639 & 638.576 & 1.486 .550 \\
1985 & 426.367 & 50.166 & 423.763 & 662.608 & 1.562 .904 \\
1986 & 493.166 & 38.295 & 380.695 & 469.566 & 1.381 .722 \\
1987 & 434.998 & 26.935 & 398.522 & 604.550 & 1.465 .005 \\
1988 & 365.155 & 27.035 & 435.002 & 481.830 & 1.309 .022 \\
1989 & 412.712 & 54.735 & 413.701 & 539.309 & 1.420 .457 \\
1990 & 397.107 & 42.680 & 404.066 & 526.575 & 1.370 .428 \\
\hline Tx. Cresc. & $-1,65$ & $-2,68$ & 0.91 & $-3,01$ & $-1,50$ \\
\hline Signif. $10 \%$ & sim & não & sim & sim & sim \\
\hline
\end{tabular}

Fonte: Pesquisa Nacional por Amostra de Domicilio - PNAD, Paraná, 1981-90.

Notas:(1) A PNAD de 1991 não foi publicada em virtude do Censo Demográfico, e em 1994 não foi feito o levantamento.

(2) Taxa de crescimento anual percentual $(\beta)$, foi estimada a partir da Função $Y_{i}=\alpha . e^{\beta . t} . u_{i}$, onde: $Y_{i}=$ quantidade de pessoas ocapadas em cada uma das categorias na atividade agricola, no Paraná e; $t_{i}=$ tempo em ano. 
Observe na Tabela 10 que o processo de redução do pessoal ocupado na agropecuária paranaense, segundo dados das PNADs, ocorre, principalmente, a partir de 1986. No período de 1981 a 1985 não houve queda no número total de pessoas ocupadas na agropecuária paranaense segundo as PNADs. Não obstante, caíram os empregados e empregadores. Esta queda do volume de empregados e o pequeno aumento do total de pessoas ocupadas entre 1981 e 1985, segundo as PNADs, é compatível com os resultados dos Censos Agropecuários (ver Tabela 9).

No periodo seguinte, 1992 a 1996, continuou a diminuir o número de pessoas ocupadas na agropecuária. Isto se deveu à queda do número de empregadores, conta-própria e dos sem remuneração. Já a categoria empregado teve sensiveis oscilações. As únicas taxas de crescimento que foram significativas, segundo os dados da Tabela 11, foram a dos conta própria $(-6,16 \%$ a. a.) e a dos sem remuneração $(-8,89 \%$ ao ano $)$.

Tabela 11 Categorias de pessoas ocupadas que tinham trabalho na semana de referência na atividade agropecuária no Paraná, 1992-96.

\begin{tabular}{lccccc}
\hline Anos & Empregado & Empregador & Cont. própria & Sem remun. & Total \\
\hline 1992 & 347.592 & 43.885 & 335.629 & 538.124 & 1.265 .230 \\
1993 & 250.316 & 32.741 & 311.558 & 510.705 & 1.105 .320 \\
1995 & 333.127 & 32.551 & 283.137 & 473.579 & 1.033 .394 \\
1996 & 334.442 & 34.575 & 282.220 & $410.29 / 7$ & 1.061 .534 \\
\hline Tx. Cresc.1 & 1,70 & $-4,30$ & $-6,16$ & $-8,89$ & $-5,01$ \\
\hline Signif. 10\% & não & não & sim & sim & não \\
\hline
\end{tabular}

Fonte: Pesquisa Nacional por Amostra de Domicilio - PNAD, Paraná, 1992-96.

(1) Taxa de crescimento anual percentual $(\beta)$, foi estimada a partir da Função $Y_{i}=\alpha \cdot e^{\beta . t} \cdot u_{i}$, onde: $Y_{i}=$ quantidade de pessoas ocupadas em cada uma das categorias na atividade agrícola, no Paraná $\mathrm{e} ; t_{i}=$ tempo em ano.

Sobre a composição percentual do pessoal ocupado na agropecuária, pode-se verificar, na Figura 5, que a categoria de pessoal ocupado sem remuneração foi a mais importante nas atividades agrícolas do Paraná entre 1981-95. Verifica-se, também, que as participações dos empregados e dos sem remuneração no total de pessoas ocupadas caminham em sentido oposto na maior parte da série. 


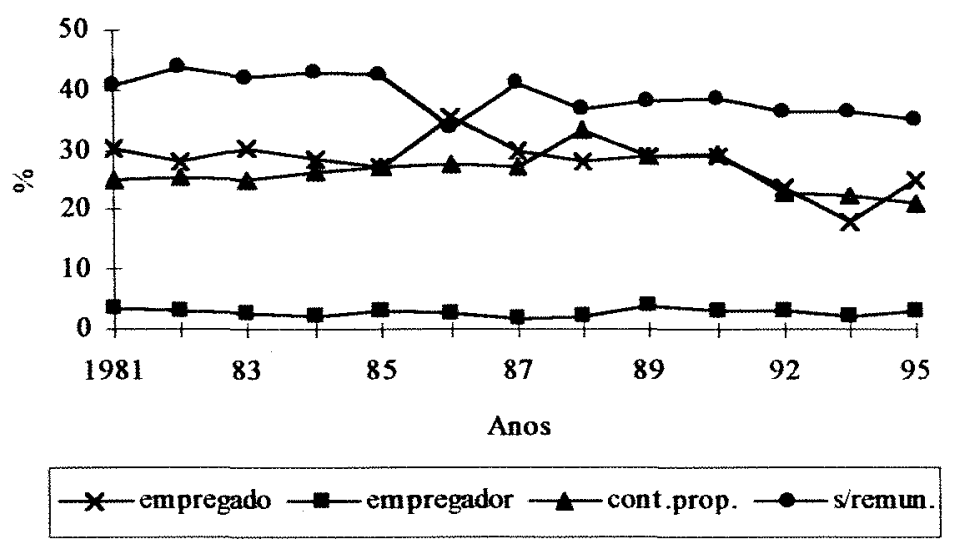

Figura 5 Participação das posições na ocupação das pessoas ocupadas na atividade agropecuária no Paraná, 1981-95.

Fonte: Pesquisa Nacional por Amostra de Domicilio - PNAD, Paraná, 1981-95.

$\mathrm{Na}$ Tabela 12 aparecem as atividades rurais ${ }^{16}$ que mais empregam força de trabalho. $\mathrm{O}$ milho foi a atividade que mais empregou mão-de-obra ao longo dos anos 90 . Em média, 24\% das pessoas envolvidas nas atividades rurais no Paraná trabalhavam no cultivo do milho. A cotonicultura e a cafeicultura vêm perdendo importância relativa frente às demais atividades na ocupação da mão-de-obra. Em valores absolutos, em 1996 a cotonicultura empregava 125 mil pessoas a menos do que em 1992 e o café menos 70 mil pessoas, de acordo com os microdados da PNAD.

A criação de aves e animais tem ampliado o número de pessoas ocupadas entre os anos de 1992 e 1996, em 18 mil e 36 mil pessoas, respectivamente, ampliando, assim, sua participação no total de pessoas ocupadas (ver a Tabela 12).

\footnotetext{
${ }^{16}$ Considera-se como atividade rural as atividades ligadas à agricultura, silvicultura, pecuária, extração vegetal, pesca. piscicultura (para efeito do nosso trabalho não consideramos as atividades ligadas à pesca e piscicultura, por não se tratar de objetivo do trabalho a análise desta atividade) e o serviço auxiliar de alguma destas atividades
} 
Tabela 12 Distribuição percentual das pessoas ocupadas nas atividades rurais no Paraná, $1992,93,95$ e 96

\begin{tabular}{lrrrr}
\hline Atividades rurais & 1992 & 1993 & 1995 & 1996 \\
\hline Cotonicultura & 8,96 & 4,74 & 3,62 & 0,54 \\
Rizicultura & 0,43 & 0,62 & 1,15 & 0,40 \\
Cafeicultura & 11,19 & 9,08 & 5,88 & 7,75 \\
Cana-de-açúcar & 3,45 & 4,90 & 4,60 & 5,68 \\
Fumo & 3,29 & 2,43 & 2,49 & 2,42 \\
Mandioca & 3,37 & 4,19 & 3,51 & 4,05 \\
Milho & 24,66 & 27,16 & 19,36 & 23,73 \\
Soja & 9,61 & 8,05 & 8,88 & 9,04 \\
Trigo & 0,77 & 1,61 & 0,09 & 1,33 \\
Produção de verduras & 9,04 & 9,72 & 7,50 & 7,41 \\
Silvicultura & 1,35 & 1,24 & 1,65 & 0,96 \\
Culturas diversas & 8,61 & 11,58 & 16,22 & 13,41 \\
Criação de animais & 9,19 & 6,83 & 13,78 & 12,62 \\
Criação de aves & 5,48 & 5,65 & 8,39 & 6,59 \\
Criação de abelhas & & 1,46 & 1,62 & 2,05 \\
Agropecuária & 0,13 & 0,16 & 0,29 & 1,08 \\
Extração erva-mate & & & 0,17 & \\
Madeira & & 0,41 & 0,46 & 0,25 \\
Carvão & & & 0,04 & 0,07 \\
Extração de ervas & & 0,07 & 0,02 & 0,05 \\
Agenc. de mão-de-obra & 0,46 & 0,10 & 0,29 & 0,58 \\
\hline Total & 100,00 & 100,00 & 100,00 & 100,00 \\
\hline Tol Dados
\end{tabular}

Fonte: Dados elaborados a partir dos microdados da PNAD.

A participação do tipo de ocupação encontrada em cada uma das atividades pode ser observada na Tabela 13. Ressalta-se a importância da agricultura familiar (conta-própria) com $21,71 \%$ e o trabalhador não remunerado com $35,80 \%$ no total geral. $\mathrm{O}$ milho, atividade que mais absorve mão-de-obra, é uma atividade que tem na agricultura familiar seu maior aliado, pois, o conta-própria juntamente com o trabalhador membro da unidade domiciliar sem remuneração responderem, em média, por $80,36 \%$ do pessoal ocupado nesta atividade.

O trabalhador não remunerado tem importância significativa em praticamente todas as atividades desenvolvidas no meio rural. Apenas para cana-deaçúcar e silvicultura este tipo de trabalhador apresentou pequena importância relativa. Para as demais atividades, segundo os microdados da PNAD, o trabalhador não 
remunerado, no Paraná, teve importância significativa junto ao processo produtivo das principais atividades no meio rural.

Tabela 13 Participação do tipo de ocupação nas atividades desenvolvidas no meio rural, do Paraná, 1992, 93, 95 e 96 (valores em percentuais).

\begin{tabular}{|c|c|c|c|c|c|c|c|}
\hline $\begin{array}{l}\text { Atividade principal } \\
\text { Empreendimento } \\
\end{array}$ & $\begin{array}{l}\text { Empregado } \\
\text { Permanente } \\
\end{array}$ & $\begin{array}{l}\text { Empregado } \\
\text { Temporário } \\
\end{array}$ & $\begin{array}{c}\text { Conta própria } \\
\text { Agricultura }\end{array}$ & $\begin{array}{r}\text { Empregador } \\
\text { Agricultura } \\
\end{array}$ & $\begin{array}{c}\text { Trabalhador } \\
\mathrm{n} / \text { remun. }\end{array}$ & $\begin{array}{c}\text { Trab. prod. } \\
\text { prop. consumo }\end{array}$ & Total \\
\hline Cotonicultura & 2,42 & 12,87 & 27,25 & 5,44 & 51,15 & 0,88 & 100,00 \\
\hline Rizicultura & 5,02 & 12,55 & 20,32 & & 36,83 & 25,28 & 100,00 \\
\hline Cafeicultura & 11,11 & 19,84 & 21,44 & 2,83 & 43,08 & 1,70 & 100,00 \\
\hline Cana-de-açúcar & 34,33 & 60,41 & 1,75 & 1,76 & 1,76 & & 100,00 \\
\hline Fumo & 2,60 & 1,59 & 30,76 & 2,60 & 61,79 & $0 ., 66$ & 100,00 \\
\hline Mandioca & 3,75 & 44,41 & 15,77 & 3.71 & 24,02 & 8,34 & 100,00 \\
\hline Milho & 3,29 & 10,76 & 33,10 & 1,12 & 47,26 & 4,48 & 100,00 \\
\hline Soja & 12,95 & 10,21 & 30,37 & 8,63 & 37,35 & 0,48 & 100,00 \\
\hline Trigo & 23,33 & 13,73 & 20,11 & 10,28 & 32,55 & & 100,00 \\
\hline Prod. Verduras & 5,29 & 3,60 & 8,17 & 1,33 & 14,90 & 66,70 & 100,00 \\
\hline Silvicultura & 77,20 & 14,45 & 0,00 & 2,40 & 5,95 & & 100,00 \\
\hline Culturas diversas & 7,47 & 9,23 & 26,18 & 2,00 & 46,04 & 9,08 & 100,00 \\
\hline Criação de animais & 30,03 & 3,86 & 16,93 & 6,73 & 29,58 & 12,87 & 100,00 \\
\hline Criação de aves & 5,13 & 8,08 & 2,08 & & 10,37 & 74,33 & 100,00 \\
\hline Criação de abelhas & $7 ., 49$ & 8,18 & 24,72 & & 59,60 & & 100,00 \\
\hline Agropecuária & 29,79 & 12,44 & 9,54 & & 37,66 & 10,57 & 100,00 \\
\hline Extração erva-mate & & & & & 100,00 & & 100,00 \\
\hline Madeira & & 68,40 & & & 31,60 & & 100,00 \\
\hline Carvão & & 100,00 & & & & & 100,00 \\
\hline Extração de ervas & & & & & 100,00 & & 100,00 \\
\hline $\begin{array}{l}\text { Agenc. De mão-de- } \\
\text { obra }\end{array}$ & 87,77 & & & & 12,23 & & 100,00 \\
\hline Total & 11,39 & 13,62 & 21,71 & 3,01 & 35,80 & 14,47 & 100,00 \\
\hline
\end{tabular}

A atividade canavieira tem nos empregados permanentes $34,33 \%$ do total utilizado de mão-de-obra e os empregados temporários representam $60,41 \%$ do total utilizado, sendo estes suas principais fontes de mão-de-obra. $\mathrm{O}$ empregado temporário teve, também, grande importância na execução das tarefas nas atividades ligadas à madeira e à mandioca, de acordo com dados da Tabela 13. A importância do empregado permanente fez-se maior nas seguintes atividades: silvicultura, criação de animais e agropecuária, embora nesta última não tem sido a fonte principal de mão-deobra. 


\section{4- Qualificação da mão-de-obra envolvida nas atividades rurais do Paraná}

Os Censos Demográficos permitem algumas observações mais detalhadas com relação à qualificação do pessoal ocupado nas atividades agropecuárias e de extração vegetal.

A Tabela 14 traz o nível de escolaridade do trabalhador da agropecuária no Paraná nos anos 1970 e 1991. Verifica-se, em temos percentuais, uma redução dos trabalhadores com apenas o ensino elementar $\left(1^{\underline{a}}\right.$ a $4^{\underline{a}}$ série do $1^{0}$ grau$)$ de $97,57 \%$ em 1970 para $82,77 \%$ do total de trabalhadores da agropecuária em 1991. Os trabalhadores dos demais níveis de escolaridade têm aumentado suas participações no total de trabalhadores rurais: os trabalhadores com o primeiro e o segundo graus passaram de 2,35\% e 0,07\% em 1970 para $11,40 \%$ e $5,4 \%$ dos trabalhadores da agropecuária em 1991, respectivamente.

Tabela 14 Nivel de escolaridade, participação percentual e taxa de crescimento para o trabalhador da agropecuária no Paraná, 1970 e 1991.

\begin{tabular}{|c|c|c|c|c|c|}
\hline \multirow{2}{*}{ Nivel escolaridade } & \multicolumn{2}{|c|}{1970} & \multicolumn{2}{|c|}{1991} & \multirow{2}{*}{$\begin{array}{l}1970-91 \\
\text { tx.cresc }\end{array}$} \\
\hline & Absoluto & $\%$ & Absoluto & $\%$ & \\
\hline Elementar & 143.009 & 97,57 & 369.941 & 82,77 & 160,68 \\
\hline $1^{\circ}$ grau & 3.443 & 2,35 & 50.969 & 11,40 & $1.388,58$ \\
\hline $2^{\circ}$ grau & 106 & 0,07 & 24.115 & 5,40 & $22.650,00$ \\
\hline Superior & 7 & 0,00 & 1.948 & 0,44 & $27.728,57$ \\
\hline Total & 146.565 & 100,00 & 446.973 & 100,00 & 207,30 \\
\hline
\end{tabular}

Este fato, entretanto, não descaracteriza a baixa qualificação do trabalhador agropecuário, pois, ainda em sua grande maioria, o nível de escolaridade é muito baixo. Em 1991 mais de $82 \%$ dos trabalhadores tinham cursado somente ensino elementar. Como se observou anteriormente, na análise dos dados do Censo Agropecuário, houve grande redução no número de pessoas ocupadas na agropecuária, implicando, possivelmente, maior desemprego das pessoas com baixo nível de escolaridade. 
Com o intuito de verificar a qualificação da mão-de-obra ocupada na agropecuária e sua evolução buscou-se, nos Censos Demográficos e nos microdados da PNAD, informações acerca do tipo de ocupação e qualificação ${ }^{17}$ dos empregados na agropecuária.

A qualificação da mão-de-obra pode ser observada na Tabela 15, onde o pessoal ocupado nas atividades agropecuárias e de extração vegetal encontram-se divididos em dois grupos: um contendo a mão-de-obra com algum tipo de qualificação e outro com mão-de-obra que não requer qualificação.

Tabela 15 Participação percentual da mão-de-obra qualificada e não qualificada ${ }^{1}$ nas atividades agropecuárias e de extração vegetal, Paraná, 1970, 1980 e 1991.

\begin{tabular}{lrrr}
\hline Tipo de ocupação & $\mathbf{1 9 7 0}$ & $\mathbf{1 9 8 0}$ & 1991 \\
\hline Mão-de-obra qualificada & $\mathbf{1 , 6 6}$ & $\mathbf{5 , 9 4}$ & $\mathbf{6 , 5 8}$ \\
Administrador na agropecuária & 0,56 & 1,42 & 1,54 \\
Auxiliares de escritório e adm. & 0,06 & 0,11 & $\mathbf{0 , 2 3}$ \\
Agrônomos & 0,00 & 0,01 & 0,04 \\
Veterinários & 0,00 & 0,01 & 0,02 \\
Técnicos agrícolas & 0,02 & 0,05 & 0,11 \\
Tratoristas/outros operadores & 0,74 & 3,73 & $\mathbf{3 , 7 4}$ \\
Motorista & 0,24 & 0,47 & 0,43 \\
Ocup. na ind. de madeira e móveis & 0,04 & 0,15 & 0,48 \\
& & & \\
Mão-de-obra pouco qualificada & $\mathbf{9 8 , 3 4}$ & $\mathbf{9 4 , 0 6}$ & $\mathbf{9 3 , 4 2}$ \\
Madeireiros e lenhadores & 1,06 & 0,44 & 1,03 \\
Carvoeiros & 0,01 & 0,05 & 0,15 \\
Ervateiros & 0,05 & 0,16 & 0,14 \\
Apanhadores, descascadores e & & & \\
"quebra"dores de produtos veg. & 0,12 & 0,03 & $\mathbf{0 , 2 3}$ \\
Mecânico s/qualificação & 0,00 & 0,04 & $\mathbf{0 , 0 3}$ \\
Pedreiros & 0,01 & 0,04 & 0,03 \\
Serventes & 0,02 & 0,03 & 0,03 \\
Outros trab. na agropecuária & 97,07 & 93,27 & 91.79 \\
\hline Total & $\mathbf{1 0 0 , 0 0}$ & $\mathbf{1 0 0 , 0 0}$ & $\mathbf{1 0 0 , 0 0}$ \\
\hline
\end{tabular}

Fonte: Censo Demográfico do Paraná referente à mão-de-obra, 1970, 1980 e 1991.

Nota (1): Para classificação dos tipos de ocupação em mão-de-obra qualificada e não qualificada levou-se em consideração a qualificação exigida para desempenhar as tarefas.

\footnotetext{
${ }^{17}$ Considerou-se qualificado aquele tipo de ocupação que no exercício de suas funções exige-se algum tipo de especialização.
} 
Verifica-se um aumento, ao longo das décadas, da participação da mão-de-obra qualificada no total de pessoas ocupadas, passando de 1,66\% em 1970 para 5,94\% em 1980 e $6,58 \%$ em 1991. As categorias de trabalhadores de maior importância dentro deste grupo são os administradores na agropecuária e os tratoristas e outros operadores que representavam, em $1970,0,56 \%$ e $0,74 \%$ do total de pessoas ocupadas, respectivamente; passando, em 1991, estes percentuais a $1,54 \%$ e $3,74 \%$, respectivamente.

A mão-de-obra não qualificada vem perdendo importância, passando de $98,34 \%$, em 1970, para $93,42 \%$ do pessoal ocupado na agropecuária em 1991. A ocupação de maior importância dentro deste grupo refere-se aos "outros trabalhadores na agropecuária", com 97,07\%, em 1970, e $91,79 \%$ do total de pessoas ocupadas na agropecuária em 1991.

$\mathrm{Na}$ categoria "outros trabalhadores na agropecuária" encontramse os chacareiros, hotelãos, floricultores, jardineiros, trabalhadores de enxada, trabalhadores na pecuária e produtores agropecuários autônomos. Não foi possível a desagregação destas categorias em função de mudanças na agregação de variáveis nos Censos Demográficos de 1970, 1980 e 1991. A única referência que pode ser feita é de que em 1970, de acordo com dados do Censo Demográfico de 1970, os trabalhadores de enxada representavam $94,69 \%$ do total de trabalho não qualificado nas atividades rurais no Paraná.

Os dados das PNADs permitem uma análise mais recente da evolução da qualificação da mão-de-obra rural no Paraná. Na Tabela 16, verifica-se a ocupação exercida, na semana de referência, em atividades rurais no período de 1992 a 1996. Apesar da diversidade de trabalho encontrada nas atividades rurais, as que merecem maior destaque são: empregador agrícola, agricultor por conta própria, operador agrícola e trabalhador rural, sendo este último de maior importância juntamente com o por conta própria (agricultura familiar). 
Tabela 16 Participação percentual das ocupações exercida na semana de referência em atividades rurais no Paraná, 1992, 93, 95 e 96.

\begin{tabular}{lcccc}
\hline Ocupação na semana de referência & 1992 & 1993 & 1995 & 1996 \\
\hline Empregador agrícola & 2,79 & 2,29 & 3,00 & 2,44 \\
Criador pequenos animais & 0,12 & 0,04 & 0,04 & 0,15 \\
Criador animais & 0,08 & - & 0,13 & 0,24 \\
Dirigente agricultura & 0,36 & 0,49 & 0,61 & 0,61 \\
Ajudante administrativo & 0,17 & 0,06 & 0,06 & - \\
Agrônomo & - & - & 0,10 & 0,05 \\
Agricultor conta própria & 22,40 & 21,63 & 20,28 & 22,47 \\
Técnico agrícola & 0,09 & 0,04 & 0,17 & 0,07 \\
Operador agrícola & $\mathbf{4 , 0 8}$ & 3,07 & 3,99 & 4,63 \\
Trabalhador rural & 67,38 & 70,24 & 68,80 & 66,75 \\
Trab. Rural pequenos animais & 0,04 & 0,21 & 0,17 & 0,20 \\
Trab. Rural - pesca & 0,58 & 0,41 & 0,85 & 0,78 \\
Trab. Rural - madeira & 0,58 & 0,21 & 0,21 & 0,15 \\
Trab. Rural - lenha & 0,18 & 0,40 & 0,30 & 0,39 \\
Trab. Rural - carvão & - & - & 0,04 & 0,02 \\
Trab. Rural - coleta & 0,25 & - & 0,13 & - \\
Serrador de madeira & - & 0,08 & 0,04 & - \\
Motorista & 0,15 & 0,22 & 0,25 & 0,56 \\
Guarda - vigia & 0,08 & - & 0,10 & - \\
Servente faxineiro & 0,04 & - & 0,04 & - \\
Alugador de eq. Agrícolas & 0,04 & - & 0,04 & - \\
Ajudante diversos & 0,23 & 0,49 & 0,42 & 0,34 \\
Diversos & 0,36 & 0,12 & 0,21 & 0,15 \\
\hline Total & 100,00 & 100,00 & 100,00 & 100,00 \\
\hline Fon Da & & & &
\end{tabular}

Fonte: Dados elaborados a partir dos microdados da PNAD.

Observando apenas as ocupações relativas a empregados, verifica-se a importância da ocupação trabalhador rural, representando, em média $68 \%$ das ocupações, seguida do operador agrícola com 4\%. A ocupação de trabalhador rural refere-se a mão-de-obra de menor qualificação ocupada no meio rural. Trata-se do trabalhador braçal, de enxada, vaqueiro, roceiro, colhedor (de algodão, cana-de-açúcar, café, banana, fumo, etc.), arrancador, tratador de animais, bóia-fria, tocador de gado, peão de estábulo, limpador de pasto, espalhador de adubo, dentre outros. Observe que há, desde 1993, uma clara tendência de queda do uso relativo desse tipo de mão-de-obra.

A ocupação operador agrícola é um trabalhador com maior qualificação em relação ao trabalhador rural. Nesta ocupação encontram-se: tratorista, operador de semeadeira, roçadeira, máquinas agrícolas, incubadora, colhedeira, 
adubadeira e incubador de ovos. Desde 1993 tem havido aumento no uso relativo desta categoria.

Estas constatações indicam a continuidade do avanço do uso de mão-de-obra qualificada na agropecuária do Paraná na década de 90.

Com o objetivo de verificar os tipos de vínculo empregatício de maior importância nas principais ocupações, trabalhador rural e operador agricola, foi construída a Tabela 17 . Nesta pode-se verificar que a ocupação de maior qualificação nas atividades rurais, operador agrícola, é em sua maioria desempenhado por trabalhador não-remunerados e por empregado permanente na agricultura. $\mathrm{O}$ trabalhador de menor qualificação, trabalhador rural, tem a maior parte de seus integrantes como trabalhadores não-remunerados, seguidos dos trabalhadores produzindo para o próprio consumo e dos empregados temporários e permanentes.

Tabela 17 Tipos de vínculos empregatícios encontrados nas ocupações do operador agrícola e dos trabalhadores rurais no Paraná, 1992, 93, 95 e 96.

\begin{tabular}{|c|c|c|c|c|c|c|c|c|}
\hline \multirow[t]{2}{*}{ Tipos de vinculo empregatício } & \multicolumn{2}{|c|}{1992} & \multicolumn{2}{|c|}{1993} & \multicolumn{2}{|c|}{1995} & \multicolumn{2}{|c|}{1996} \\
\hline & Operador & Trab. & Operador & Trab. & Operador & Trab. & Operador & Trab. \\
\hline Empregado & 34,05 & 11,67 & 48,08 & 10,53 & 31,92 & 10,81 & 34,87 & 14,09 \\
\hline Empregado & 8,51 & 17,23 & 12,02 & 18,75 & 11,70 & 16,83 & 1,62 & 20,00 \\
\hline Inerado & 49,58 & 50,15 & 34,72 & 49,20 & 52,13 & 47,55 & 49,28 & 45,53 \\
\hline Trab. prod. próprio consumo & 7,03 & 20,07 & 1,34 & 20,18 & 1,06 & 22,65 & 0,00 & 19,04 \\
\hline Outros $^{1}$ & 0,83 & 0,88 & 3.85 & 1,33 & 3,19 & 2,16 & 4.23 & 1,34 \\
\hline Total & 100,00 & 100,00 & 100,00 & 100,00 & 100,00 & 100,00 & 100.00 & 100,00 \\
\hline
\end{tabular}

a partir dos microdados da PNAD.

Nota: (1) Neste item são considerados: empregado permanente em serviço auxiliar e em outra atividade; conta própria empregado em servipo auxiliar, na agricultura e em outra atividade; empregados agrioola em outra atividade, e, outro trabalho não-remunerado. 


\section{6- ESTIMATIVAS DAS EQUAÇÕES DE DETERMINAÇÃO DOS SALÁRIOS}

Este capítulo analisa o comportamento dos salários dos trabalhadores da agropecuária paranaense entre 1977 e 1996 e identifica seus fatores determinantes. Em função da disponibilidade dos dados, apenas três categorias de trabalhadores são investigadas: tratorista, mensalista e diarista. Classificou-se como trabalhador permanente o tratorista e o mensalista; e como trabalhador temporário, o diarista.

\section{1- Comportamento dos salários dos trabalhadores na agropecuária paranaense}

O rendimento de grande parte das pessoas ocupadas nas atividades agropecuárias no Paraná não ultrapassa um salário mínimo. Considerando as pessoas ocupadas sem rendimento juntamente com o pessoal ocupado que recebia até um salário mínimo, tem-se que em 1980 e 1991 estes representavam por volta de $80 \%$ do total de pessoas ocupadas de 10 anos ou mais na agropecuária paranaense (segundo dados dos Censos Demográficos do Paraná referente à mão-de-obra, 1980 e 1991).

Com base nos dados da Tabela 18 verifica-se que a maior parcela do pessoal ocupado nas atividades agropecuárias no Paraná encontram-se sem rendimento, $59,58 \%$ em 1980 e $54,19 \%$ em 1991. As pessoas ocupadas que recebiam mais de $1 / 2$ e até um salário mínimo representavam em 1980 12,17\% e em 1991 16,34\%, já as pessoas ocupadas que encontravam-se nas classes de salário de 1 a 1 e $1 / 2$ salário mínimo representavam $9,38 \%$ em 1980 e $8,35 \%$ em 1991 do total de pessoas ocupadas. 
Tabela18 Participação das pessoas ocupadas nas atividades agropecuárias com 10 anos ou mais de idade, segundo as classes de rendimento médio mensal em salários mínimos, Paraná 1980 e 1991.

\begin{tabular}{lrr}
\hline Classes de rendimento mensal & 1980 & 1991 \\
\hline Até $1 / 4$ & 1,58 & 0,91 \\
Mais de $1 / 4$ a $1 / 2$ & 5,82 & 7,87 \\
Mais de $1 / 2$ a 1 & 12,17 & 16,34 \\
Mais de 1 a 1 1/2 & 9,38 & 8,35 \\
Mais de 1 1/2 a 2 & 3,34 & 3,34 \\
Mais de 2 a 3 & 3,53 & 3,58 \\
Mais de 3 a 5 & 2,44 & 1,87 \\
Mais de 5 a 10 & 1,25 & 1,29 \\
Mais de 10 a 20 & 0,49 & 0,45 \\
Mais de 20 & 0,23 & 0,21 \\
Sem rendimento & 59,58 & 54,19 \\
Sem declaração & 0,19 & 1,60 \\
\hline Total & 100,00 & 100,00 \\
\hline Fonte: Censo Demografíco do Paraná referente à mão-de-obra, 1980 e 1991.
\end{tabular}

Considerando-se apenas os salários das três categorias de trabalhadores que são analisadas no trabalho (tratorista, mensalista e diarista), pode-se observar na Tabela 19 que eles encontram-se acima de um salário mínimo.

Analisando o comportamento do piso salarial (em salários mínimos) do trabalhador permanente no período compreendido entre 1977 e 1996, verifica-se no caso do mensalista, de acordo com os dados da Tabela 19, que sua base salarial em 1977 era de 1,6 salário mínimo, foi reduzida para 1,4 em 1987 e chegando em 1996 a 2,6 salários minimos. Para o tratorista esta relação passou de 2,1 em 1977 para 1,9 em 1987 e 3,5 em 1996. Estes resultados mostram um ganho em termos de salários mínimos maior a partir de 1987. 
Tabela 19 Número de salários mínimos que os trabalhadores rurais recebiam no Paraná e taxa de crescimento ${ }^{1}, 1977-96$.

\begin{tabular}{|c|c|c|c|}
\hline Anos & Mensalista/mínimo & Tratorista/mínimo & Diarista/mínimo diário ${ }^{2}$ \\
\hline 1977 & 1,62 & 2,08 & 1,80 \\
\hline 1978 & 1,51 & 1,96 & 1,63 \\
\hline 1979 & 1,33 & 1,78 & 1,56 \\
\hline 1980 & 1,27 & 1,57 & 1,66 \\
\hline 1981 & 1,27 & 1,63 & 1,85 \\
\hline 1982 & 1,33 & 1,77 & 1,77 \\
\hline 1983 & 1,25 & 1,64 & 1,63 \\
\hline 1984 & 1,41 & 1,76 & 1,44 \\
\hline 1985 & 1,29 & 1,89 & 1,71 \\
\hline 1986 & 1,31 & 2,05 & 2,01 \\
\hline 1987 & 1,35 & 1,90 & 2,42 \\
\hline 1988 & 1,88 & 1,98 & 1,56 \\
\hline 1989 & 2,02 & 2,28 & 1,73 \\
\hline 1990 & 2,30 & 3,36 & 2,07 \\
\hline 1991 & 2,39 & 3,02 & 2,46 \\
\hline 1992 & 2,49 & 3,05 & 1,93 \\
\hline 1993 & 2,26 & 3,29 & 1,65 \\
\hline 1994 & 2,29 & 4,09 & 2,17 \\
\hline 1995 & 2,65 & 2,83 & 3,17 \\
\hline 1996 & 2,61 & 3,54 & 2,86 \\
\hline Taxa. Crescimento & 4,07 & 4,24 & 2,33 \\
\hline Sigficância 1\% & sim & $\operatorname{sim}$ & $\operatorname{sim}$ \\
\hline \multicolumn{4}{|c|}{ Fonte: Dados elaborados a partir das informações contidas na Tabela 20.} \\
\hline $\begin{array}{r}\text { Notas: (1) A taxa de } \\
\text { dos trabalhado }\end{array}$ & $\begin{array}{l}\text { ento anual ( } \beta \text { ) foi estimad } \\
\text { is do Paraná e salário minim }\end{array}$ & $\begin{array}{l}\text { da Função } Y_{i}=\alpha \cdot e^{\beta} \\
\text { mpo em ano, e u } u_{i} \text { é orro a }\end{array}$ & $Y_{i}=$ relação entre salários \\
\hline
\end{tabular}

Observando-se a evolução da relação entre os salários dos trabalhadores permanentes e o salário mínimo, na Figura 6, verifica-se que a partir de 1987 a base de correção dos salários destes deixou de ser o salário mínimo, pois, estes tiveram um ganho real em relação ao salário mínimo.

No caso do salário do trabalhador temporário, o diarista, observa-se na Figura 6 uma instabilidade na relação entre seu salário e o salário mínimo. Com base nos dados da Tabela 19 verifica-se que, também, para esta categoria de trabalhadores rurais no Paraná houve uma melhoria em termos da relação entre seu salário e o salário mínimo que cresceu a uma taxa de 2,33\% ao ano. Cabe ressaltar, 
entretanto, que o diarista teve a menor taxa de crescimento em seu salário, comparandose com as taxas de crescimento dos salários dos trabalhadores permanentes. A categoria de trabalhador rural que teve maior ganho em relação ao salário mínimo foi a do tratorista que, de acordo com a Tabela 19, teve uma taxa de crescimento ao longo do periodo $1977-96$ de $4,24 \%$ ao ano, seguida do mensalista com $4,07 \%$ ao ano.

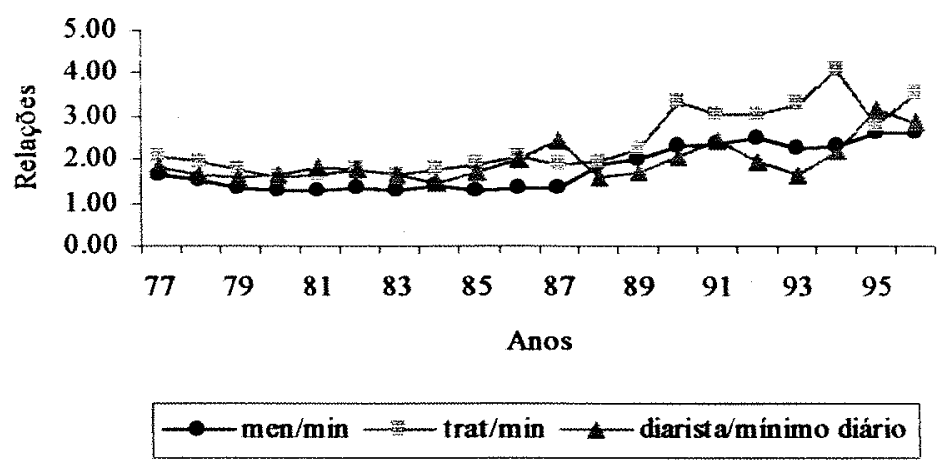

Figura 6 Número de salários mínimos que os mensalistas, tratoristas e diaristas recebiam no Paraná, 1977-96.

Fonte: Tabela 19.

A explicação para o aumento no número de salários mínimos que, principalmente, os trabalhadores permanentes passaram a receber após 1987 não se encontra no aumento da demanda por estes trabalhadores. No caso do tratorista, com base na Figura 7, pode-se verificar que o período em que mais cresceu o número de tratoristas, entre 1970 e 1980, foi quando o salário dos mesmos manteve-se relativamente estável em termos de salários mínimos. 


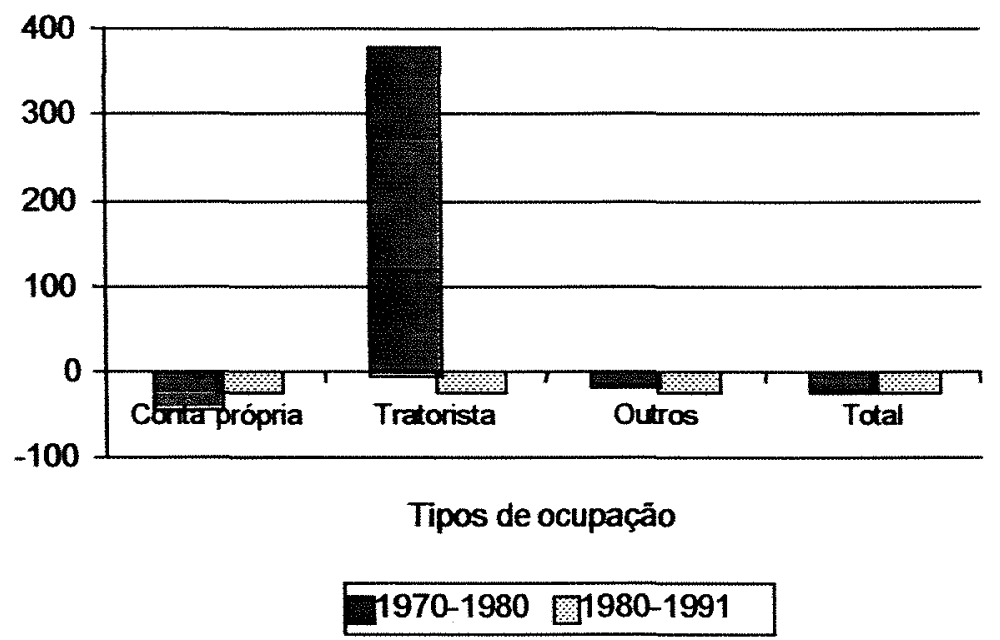

Figura 7 Taxa de crescimento das ocupações agropecuárias no Paraná, 1970-80 e 1980-91.

Fonte: Censo Demográfico do Paraná referente a mão-de-obra, 1970, 1980 e 1991.

A mudança na base de correção dos salários ocorreu justamente no periodo de inflação alta e dos planos de estabilização. Acredita-se que neste período, 1987 a 1996, o salário mínimo não tenha conseguido captar as altas taxas de inflação, perdendo com isso a sua característica, observada no período 1977-87, de base de correção dos salários dos trabalhadores rurais no Paraná.

$\mathrm{Na}$ Figura 6, verifica-se que com a estabilização de preços no Plano Real, o salário mínimo voltou a ser a base de correção do salário do mensalista. No dois últimos anos analisados, ou seja, em 1995 e 1996, houve estabilização da relação salário do mensalista e salário mínimo. Acredita-se que caso se confirme a estabilização de preços da economia, o salário mínimo voltará a ser a base de correção dos salários rurais no Paraná.

\subsection{1- Tendência dos salários}

Conforme observou-se acima, os salários dos trabalhadores rurais no Paraná (tratorista, mensalista e diarista), apresentaram ganhos em relação ao salário mínimo. A evolução e a tendência destes salários podem ser observadas nas Figuras 8 e 9 . Em relação à tendência os referidos salários, observa-se que os 
salários dos trabalhadores permanentes da agropecuária apresentaram dois movimentos, ou seja, de queda até 1987 e de crescimento após este ano. Já para o salário do diarista esta "quebra" de tendência é melhor observada no ano de 1988, como pode-se constatar na Figura 9. A linha de tendência que obteve melhor ajuste para os salários dos trabalhadores foi a polinomial, como se pode constatar nas Figuras 8 e 9 .

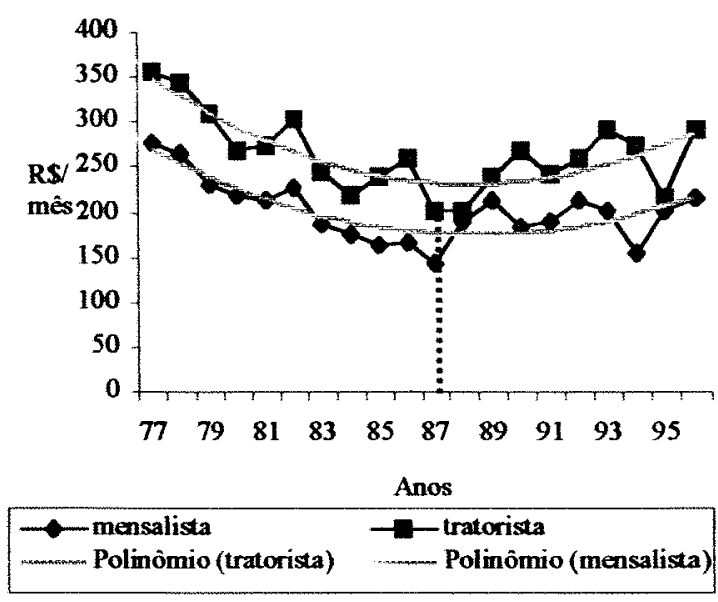

Figura 8 Salários dos trabalhadores permanentes e suas tendências, Paraná 1977-96.

Fonte: SEAB/DERAL

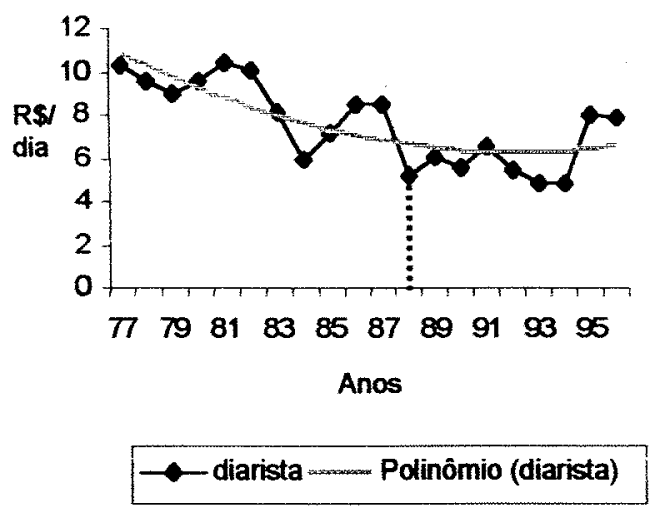

Figura 9 Salário do trabalhador temporário e sua tendência, Paraná 1977-96.

Fonte: SEAB/DERAL

Com o objetivo de verificar estatisticamente se houve "quebra" de tendência no salário dos trabalhadores agropecuários, utilizou-se o ajustamento de uma poligonal descrito por Hoffmann \& Vieira (1987). Segundo os autores, o ajuste da poligonal pode ser feito utilizando duas variáveis artificiais, "uma para representar o correr do tempo no $1^{-}$período, e outra para representar o correr do tempo no $2^{\mathrm{o}}$ período" (Hoffmann, \& Vieira 1987, p.212), no qual a tendência da variável dependente seria diferente. 
O modelo estatístico é:

$Y_{j}=\alpha+\beta_{1} \cdot V_{j}+\beta_{2} \cdot W_{j}+u_{j}$

Onde:

$Y_{j}=$ variável dependente, sendo definida da seguinte forma para as equações $(17,18$ e 19) que serão estimadas: $W T_{j}$ (salário do tratorista), $W_{M e n}$ (salário do mensalista) e $\mathrm{WV}_{\mathbf{j}}$ (salário do diarista).

$W_{j}=Z_{j} \cdot\left(X_{j}-K\right)$;

$V j=\left(I-Z_{j}\right) \cdot\left(X_{j}-K\right)$

$$
Z=\left\{\begin{array}{l}
0 \text { para } X<K \\
1 \text { para } X \geq K
\end{array}\right.
$$

$K=$ ano em que verificou-se mudança de tendência, no caso 1987 para o salário do trabalhador permanente e 1988 para salário do trabalhador temporário;

$X=$ ano; e,

$u_{\mathrm{j}}=$ erro.

No caso do ajustamento da poligonal para os salários dos tratoristas, utilizou-se o método de estimação dos mínimos quadrados ordinários, chegando-se à seguinte equação ${ }^{18}$ (onde o número entre parênteses, abaixo do coeficiente é a estatística " $\mathrm{t}$ ", $\mathrm{e}$ " $\mathrm{A}$ " indica significância de $0,1 \%$ e " $\mathrm{B}$ " significância de até $1 \%$ ):

$$
\begin{aligned}
& W T_{j}=\underset{(18,172) \mathrm{A}}{219,28}-\underset{(-5,299) \mathrm{B}}{11,70} V_{j}+\underset{(3,526) \mathrm{A}}{8,7,7} W_{j} \\
& \mathrm{R}^{2}=0,625 \quad \mathrm{n}=20 \quad \mathrm{~F}=14,143^{\mathrm{A}} \quad \mathrm{DW}=1,919 \text { (não há autocorrelaçà)) }
\end{aligned}
$$

\footnotetext{
${ }^{18}$ Os dados utilizados na estimativa encontram-se na Tabela 1.1 no Apêndice 1.
} 
Para verificar se a mudança de tendência é estatisticamente diferente de zero, testou-se a hipótese $H_{0}: \beta_{1}=\beta_{2}$. Ao nível de significância de $1 \%$ rejeitase $\mathrm{H}_{0}$, pois, o valor de " $\mathrm{t}$ " crítico é, neste caso, 2,898 e o valor de " $\mathrm{t}$ " calculado é 4,88 .

A Figura 10 mostra o ajuste da equação (17) para o caso do salário do tratorista, no Paraná, no período 1977-96. Tendo um comportamento decrescente até 1987 e ascendente após este período. Confirma-se, assim, uma "quebra" de tendência no ano de 1987 para o salário do tratorista.

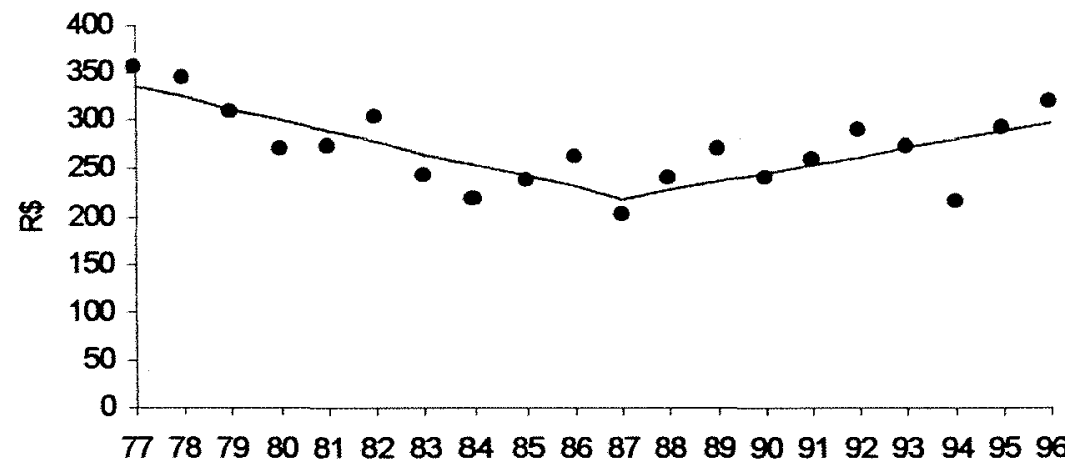

Anos

- Observado Estimado

Figura 10 Salário do tratorista observado e estimativa da tendência, Paraná 1977-96

Fonte: SEAB/DERAL e estimativa.

No salário do mensalista, como no caso do tratorista, supôs-se uma "quebra" de tendência no ano de 1987, a qual foi testada através do ajuste de uma poligonal, resultando na equação abaixo descrita (o número entre parênteses, abaixo do coeficiente estimado, é a estatística " $t$ " e " $\mathrm{A}$ " indica significância até $0,1 \%$, " $\mathrm{C}$ " significância até $5 \%$ e "E” indica significância ao nível de $20 \%$ ):

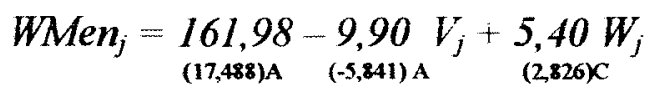

$$
\begin{aligned}
& \mathrm{R}^{2}=0,672 \quad \mathrm{n}=20 \quad \mathrm{~F}=17,398^{\mathrm{A}} \quad \mathrm{DW}=1,512_{\text {(inconclusivo) }} \quad \mathrm{Q}(5-0)=7,394^{\mathrm{E}}
\end{aligned}
$$


Como o teste Durbin-watson foi inconclusivo, fez-se o teste BoxPierce o qual não detectou presença de autocorrelação nos resíduos a baixo nível de significância estatística.

A hipótese $H_{0}: \beta_{1}=\beta_{2}$ foi rejeitada ao nivel de significância de $1 \%$. $O$ valor de " $\mathrm{t}$ " calculado foi 4,748 , maior que o valor de " $\mathrm{t}$ " crítico 2,898. Assim, como no caso do salário do tratorista, foi confirmada a "quebra" de tendência no ano de 1987 no comportamento do salário do mensalista.

Na Figura 11, encontra-se o salário do mensalista observado e o estimado com base na equação (18).

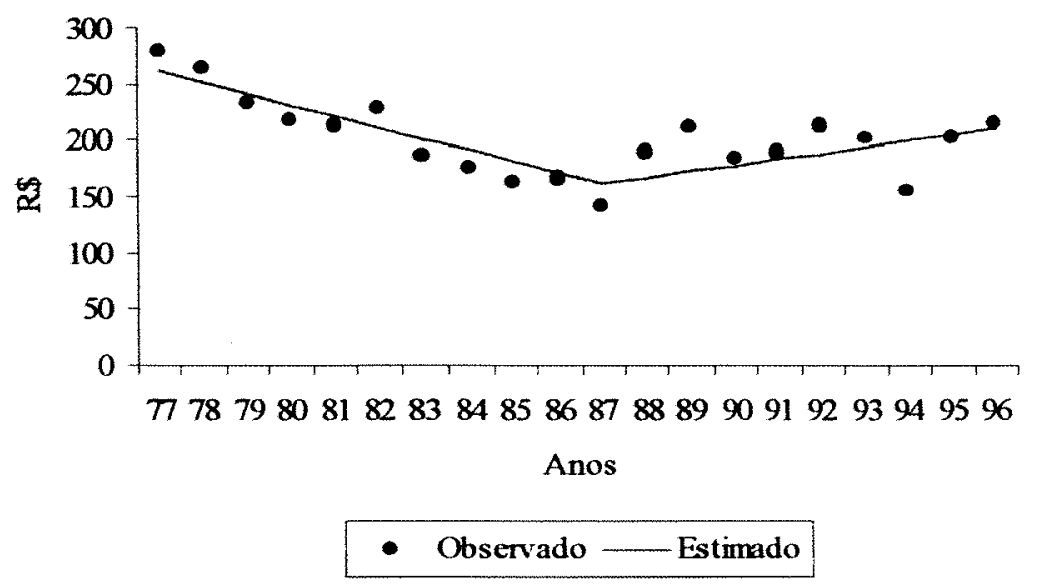

Figura 11 Salário do mensalista observado e estimativa da tendência, Paraná, 1977-96

Fonte: SEAB/DERAL e estimativa

Do exposto acima, constata-se que no Paraná os salários dos trabalhadores permanentes na agricultura apresentaram comportamentos distintos entre 1977-86 e 1987-96.

Objetivando verificar, estatisticamente, a "quebra" de tendência no salário do trabalhador temporário, diarista, ajustou-se uma poligonal e a estimativa 
desta ${ }^{19}$ é (onde o número abaixo do coeficiente é a estatística " $t$ ", " $A$ " indica significância de $0,1 \%$, "C" significância de $5 \%$ e "ns" não significativo ao nível de $20 \%$ ):

$$
W V_{j}=\underset{(11,176) \mathrm{A}}{6,18,400) \mathrm{A}} \underset{(0,342) \mathrm{ms}}{0,40} V_{j}+\underset{(0,045}{0,0} W_{j}
$$

$\mathrm{R}^{2}=0,616 \quad \mathrm{n}=20 \quad \mathrm{~F}=13,646^{\mathrm{A}} \quad \mathrm{DW}=1,353$ (inondusivo) $\quad \mathrm{Q}(5-0)=13,989^{\mathrm{C}}$

Segundo o teste Box-Pierce há autocorrelação residual. Não obstante, optou-se por manter a equação 19, pois a correção da autocorrelação implicaria alteração no valor das variáveis o que resultaria em mudança no valor das variáveis artificiais.

Ressalta-se que no caso do salário do diarista a "quebra" de tendência foi testada para o ano de 1988 , e rejeita-se a hipótese $\mathrm{H}_{0}: \boldsymbol{\beta}_{1}=\beta_{2}$ ao nível de significância de $5 \%$. Caso fosse mantida a "quebra" de tendência no ano de 1987 , a hipótese nula somente seria rejeitada a um nível de significância de $10 \%{ }^{20}$.

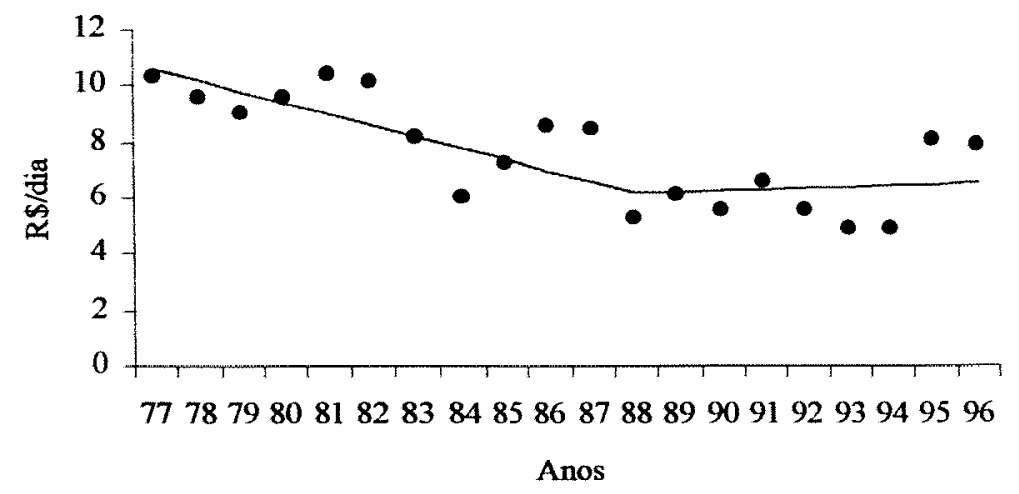

- Observado - Estimado

Figura 12 Salário do diarista observado e estimativa da tendência no Paraná, 1977-96.

Fonte: $\mathrm{SEAB} / \mathrm{DER} A \mathrm{~L}$ e extimativa

${ }^{19}$ Os dados utilizados estão na Tabela 1.1 do Apêndice 1.

${ }^{20}$ Os resultados dos testes para verificar "quebra" de tendência foram os seguintes: a) para 0 ano de 1987 o "t" calculado foi 1,$8 ; \mathrm{e}$, b) para o ano de 1988 o resultado do "t" calculado foi 2.24 . 
De acordo com a equação (19) e a Figura 12 confirma-se, também, no caso do salário do trabalhador temporário, a "quebra" de tendência, mas, esta somente obteve melhor resultado estatístico para o ano de 1988.

\section{2- Comportamento das demais variáveis que compõem os modelos de determinação dos salários}

Observada a "quebra" de tendência na evolução dos salários dos trabalhadores na agropecuária paranaense, objetiva-se, então, verificar o comportamento das demais variáveis utilizadas no modelo de determinação dos salários dos trabalhadores permanentes e temporários.

Para estimativas das equações de determinação dos salários do trabalhador rural no Paraná foram utilizadas variáveis cujos valores encontram-se expressos na Tabela 20. Os dados da Tabela 20 e das Figuras A1 a A6 (as Figuras encontram-se no Anexo "A"), mostram o comportamento dessas variáveis.

De acordo com os dados da Tabela 20, os salários mínimo (WM) e do emprego urbano alternativo (WU) apresentaram taxas de crescimento negativas ao longo do período 1977-96. O salário mínimo é o que apresentou maior decréscimo $(-5,30 \%$ a. a $)$. Este fato pode ser evidenciado na Figura $A 1$, onde se verifica que a linha de tendência para o salário mínimo teve um comportamento decrescente acentuado. No caso do salário do trabalho urbano alternativo (que é o salário do servente na indústria da construção civil em São Paulo), a taxa de crescimento foi $-2,32 \%$ ao ano, segundo dados da Tabela 20. Na Figura A2 verifica-se uma queda do salário urbano alternativo mais sensivel até 1988, havendo recuperação parcial a partir de então. 
Tabela 20 Dados utilizados para estimativas das equações de determinação dos salários dos trabalhadores rurais no Paraná e suas taxas de crescimento ${ }^{2}, 1977-96$.

\begin{tabular}{|c|c|c|c|c|c|c|c|c|c|}
\hline Anos & WV & $\overline{\mathrm{WM}}$ & WMen. & WT & WU & $\pi$ & PMO & $P$ & $\mathrm{~Pa}$ \\
\hline 77 & 10,27 & 171,27 & 278,10 & 356,99 & 1,01 & 1,76 & 100,00 & 18.072 .402 & 2,40 \\
\hline 78 & 9,53 & 175,44 & 265,00 & 344,25 & 1,08 & 1,35 & 96,00 & 13.345 .690 & 1,78 \\
\hline 79 & 8,99 & 173,44 & 231,37 & 309,07 & 1,09 & 1,24 & 105,58 & 16.476 .686 & 1,59 \\
\hline 80 & 9,52 & 172,13 & 217,81 & 269,86 & 1,01 & 0,98 & 122,58 & 20.394 .120 & 1,43 \\
\hline 81 & 10,39 & 168,10 & 212,88 & 274,20 & 0,92 & 0,76 & 133,76 & 20.277 .878 & 1,09 \\
\hline 82 & 10,12 & 171,80 & 227,69 & 303,94 & 1,07 & 0,72 & 130,15 & 21.522.969 & 0,97 \\
\hline 83 & 8,12 & 149,00 & 186,96 & 244,13 & 0,94 & 0,79 & 131,57 & 24.119 .071 & 0,96 \\
\hline 84 & 5,97 & 124,20 & 174,58 & 219,10 & 0,75 & 0,77 & 137,23 & 23.036 .377 & 1,01 \\
\hline 85 & 7,18 & 125,87 & 162,20 & 238,28 & 0,74 & 0,86 & 159,85 & 28.182 .717 & 1,09 \\
\hline 86 & 8,53 & 127,24 & 167,14 & 261,17 & 0,77 & 0,98 & 140,63 & 25.326 .018 & 1,15 \\
\hline 87 & 8,47 & 105,01 & 141,98 & 200,02 & 0,61 & 1,10 & 162,45 & 31.612 .516 & 1,21 \\
\hline 88 & 5,27 & 101,20 & 190,16 & 239,13 & 0,56 & 1,14 & 169,53 & 30.186 .561 & 1,16 \\
\hline 89 & 6,06 & 104,86 & 212,21 & 269,65 & 0,77 & 1,32 & 178,25 & 29.161 .824 & 1,22 \\
\hline 90 & 5,52 & 80,18 & 184,18 & 241,22 & 0,65 & 1,18 & 168,57 & 27.832 .022 & 0,95 \\
\hline 91 & 6,54 & 79,83 & 190,68 & 260,27 & 0,64 & 1,04 & 175,60 & 27.930 .217 & 1,08 \\
\hline 92 & 5,50 & 85,45 & 212,48 & 290,98 & 0,70 & 0,75 & 184,43 & 30.959 .890 & 0,83 \\
\hline 93 & 4,88 & 88,55 & 200,25 & 274,42 & 0,75 & 0,94 & 181,25 & 33.577 .720 & 0,90 \\
\hline 94 & 4,84 & 67,06 & 153,45 & 215,67 & 0,74 & 1,01 & 197,21 & 36.689 .718 & 0,97 \\
\hline 95 & 8,06 & 76,29 & 201,96 & 292,97 & 0,64 & 0,85 & 201,88 & 40.545 .785 & 0,86 \\
\hline 96 & 7,89 & 82,69 & 216,18 & 319,17 & 0,94 & 0,91 & 207,49 & 43.306 .941 & 0,92 \\
\hline Tx. Cres. & $-3,00$ & $-5,30$ & $-1,28$ & $-0,80$ & $-2,32$ & $-1,10$ & 3,80 & 4,80 & -3.38 \\
\hline $\begin{array}{l}\text { Signif. } \\
10 \%\end{array}$ & $\operatorname{sim}$ & $\operatorname{sim}$ & sim & não & Sim & não & $\operatorname{sim}$ & $\operatorname{sim}$ & $\operatorname{sim}$ \\
\hline
\end{tabular}

Fonte: SEAB/DERAL, Anuário Estatístico do Brasil, Construção, Conjuntura Econômica, IPARDES e Gasques \& Conceição.

OBS: (1) Definição das variáveis encontradas na tabela:(WV) salário do diarista; (WM) salário mínimo; (Wmen) salário do mensalista; (WT) salário do tratorista; (WU) salário do emprego urbano alternativo, ou seja, salário do servente na construção civil; ( $\pi$ ) lucro, calculado como sendo índice de pregos recebidos pelos produtores rurais no Paraná dividido pelo indice de precos pagos pelos mesmos; (PMO) produtividade da mão-de-obra; (P) produçăo total; $(\mathrm{Pa})$ indice de preços recebidos pelos produtores paranaenses, utilizado com proxy dos preços dos produtos recebidos pelos pequenos produtores rurais.

(2) A taxa de crescimento anual $(\beta)$ foi estimada a partir da Função $Y_{i}=\alpha \cdot e^{\beta . t} . u_{i}$, onde: $Y_{i}$ variáveis em relação às quais será calculada a taxa de crescimento, $t_{i}=$ tempo em ano, e $u_{i}$ é o erro associado.

Considerando as demais variáveis, verifica-se que a relação de preços recebidos/ pagos, considerada como proxy do lucro, também apresentou taxa de crescimento negativa de acordo com os dados da Tabela 20 (de $-1,10 \%$ a.a.), embora não tenha sido significativa ao nível de $10 \%$. Na Figura $\mathrm{A} 3$, verifica-se que a linha de tendência do lucro dos produtores rurais no Paraná apresentou uma leve tendência à queda entre 1977 a 1982 recuperando-se até 1989 e voltando a cair novamente a partir de então. A variável preços recebidos pelos produtores paranaenses apresentou taxa de crescimento de $-3,38 \%$ ao ano, confirmando, também, a tendência decrescente verificada na Figura A6 principalmente entre 1977 e 1982. A produtividade da mão-de-obra, de 
acordo com os dados da Tabela 20, apresentou taxa de crescimento positiva de $3,80 \%$ a.a., significativa ao nível de $10 \%$.

Apesar de todas as crises, inclusive com queda de lucro e dos preços recebidos pelos produtores, o setor agropecuário vem apresentando aumentos na produção, que cresceu a uma taxa de $4,80 \%$ ao ano entre 1977 e 1996 . Este fato pode ser evidenciado na Figura A5.

\section{3- Determinantes dos salários dos trabalhadores da agropecuária paranaense}

Objetiva-se neste item testar o modelo de determinação dos salários adaptado para o caso paranaense (desenvolvido no capítulo 4), buscando identificar as variáveis que mais influenciaram o comportamento dos salários dos trabalhadores permanentes e temporários na agropecuária paranaense.

As equações de determinação dos salários dos trabalhadores permanentes e temporários são as seguintes:

$$
\begin{aligned}
& W T P=Y_{0}+Y_{1} \cdot W M+Y_{2} \cdot P+Y_{3} . \pi+Y_{4} \cdot P M O \\
& W V=C_{0}+C_{1} \cdot P a+C_{2} . W U+C_{3} . W M+C_{4} \cdot P+C_{5 .} \pi+C_{6} \cdot P M O
\end{aligned}
$$

As definições das variáveis encontram-se no item 4.3.3 do capítulo 4. O modelo a ser estimado foi modificado para contemplar a utilização das variáveis artificiais, devido às "quebras" de tendência que foram observadas no item 6.1. Objetiva-se identificar as variáveis que explicaram o comportamento dos salários dos trabalhadores permanentes no $1^{\circ}$ periodo (1977 a 1986) e no $2^{\circ}$ período (1987 a 1996); e dos trabalhadores temporários, cujos períodos são: 1977 a 1987 e 1988 a 1996. Os modelos de determinação dos salários dos trabalhadores permanentes e temporários passam a ser, então: 


$$
\begin{aligned}
& W V=C_{0} \cdot(Z)+C_{1 \cdot}(1-Z)+C_{2} \cdot(Z . P a)+C_{3 \cdot}(1-Z) \cdot P a+C_{4 \cdot}(Z \cdot W U)+C_{5 \cdot}(1-Z) \cdot W U+ \\
& +C_{6 .}(Z . W M)+C_{7 .}(1-Z) \cdot W M+C_{8 \cdot}(Z . P)+C_{9 .}(1-Z) \cdot P+C_{10} \cdot(Z . \pi)+C_{11 \cdot}(1-Z) \cdot \pi+ \\
& +C_{12 \cdot}(Z \cdot P M O)+C_{13 \cdot}(1-Z) \cdot P M O
\end{aligned}
$$

$$
\begin{aligned}
W T P= & Y_{0 .}(Z)+Y_{1 \cdot}(1-Z)+Y_{2 \cdot}(Z . W M)+Y_{3 \cdot}(1-Z) . W M+Y_{4 \cdot}(Z . P)+Y_{5 \cdot(1-Z) . P+Y_{6 .}(Z . \pi)+} \\
& +Y_{7 \cdot(1-Z) . \pi}+Y_{8 .}(Z \cdot P M O)+Y_{9 .}(1-Z) \cdot P M O
\end{aligned}
$$

Onde, por exemplo, considerando a equação (22):

$Y_{0 . Z}=$ constante no primeiro período;

$Y_{1 .}(1-Z)=$ constante no segundo período;

$$
Z=\left\{\begin{array}{c}
0 \text { para } X<K \\
1 \text { para } X \geq K
\end{array}\right.
$$

$$
\begin{aligned}
& K=\text { ano em que se verificou mudança de tendência, no caso } 1987 \text { para os } \\
& \text { salários dos trabalhadores permanentes e } 1988 \text { para o salário do } \\
& \quad \text { trabalhador temporário; e, } \\
& X=\text { ano. }
\end{aligned}
$$

Ressalta-se que este modelo ${ }^{21}$ é uma adaptação do modelo de variável artificial descrito por Hoffmann \& Viera (1987), onde o mesmo foi desenvolvido apenas para captar a mudança na variável tendência. No presente caso adaptou-se este modelo com intuito de verificar as variáveis que determinam o comportamento dos salários dos trabalhadores na agropecuária paranaense.

\footnotetext{
${ }^{21}$ Optou-se por utilizar este modelo ao invés de estimar duas equações separadamente (o resultado da estimativa dos parâmetros é o mesmo, independente do método que se use), por obter-se melhores resultados em termos de $R^{2}$ e $F$.
} 


\subsection{1- Determinantes do salário do tratorista (WT)}

A estimativa da equação de determinação do salário do tratorista foi baseada nos dados da Tabela 2.1 do Apêndice 2. Obteve-se o seguinte resultado da estimativa da equação (22) para o caso do salário do tratorista (o valor entre parênteses abaixo do coeficiente estimado é a estatística " $\mathrm{t}$ ", sendo: "B" significativo ao nível de $1 \%$, "C" significativo ao nível de $5 \%$, "D" significativo ao nível de $10 \%$, "E" significativo ao nível de $20 \%$ e "ns" não significativo mesmo a $20 \%$ ) :

para o $1^{0}$ período $(1977-86)$

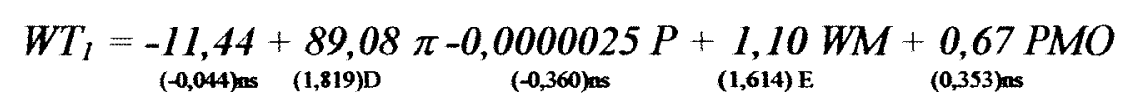

para o $2^{\circ}$ periodo (1987-96)

$$
\begin{aligned}
& W T_{2}=\underset{(-1,226) \mathrm{ns}}{-300,22}-\underset{(-1,34) \mathrm{E}}{86,21 \pi}-\underset{(-1,604) \mathrm{E}}{0,0000058 P}+\underset{(1,911) \mathrm{D}}{1,79 \mathrm{WM}}+\underset{(2,569) \mathrm{C}}{3,75 P M O} \\
& \mathbf{R}^{2}=0,812 \quad \mathrm{n}=20 \quad \mathrm{~F}=4,825^{\mathrm{B}} \quad \mathrm{DW}=2,201 \text { (inconclusivo) } \quad \mathrm{Q}(5-0)=3,779^{\mathrm{ns}}
\end{aligned}
$$

Como o teste de Durbin-Watson foi inconclusivo, fez-se o teste Box-Pierce, o qual indica não haver presença de autocorrelação nos resíduos.

Como a constante não foi estatisticamente significativa nas equações (23a) e (23b), optou-se por excluí-la do modelo por acreditar que quando as variáveis independentes (lucro, produção total, salário mínimo e produtividade da mãode-obra) forem zero, o salário do trabalhador também o será, pois não haverá motivos para produção e, consequentemente, não haverá contratação de mão-de-obra.

A equação estimada ficou, então, da seguinte forma (o valor entre parênteses abaixo do coeficiente estimado é a estatística " $t$ ", sendo: " $B$ " significativo ao nível de $1 \%$, "C" significativo ano nível de $5 \%$, " $\mathrm{D}$ " significativo ao nível de $10 \%$, "E" significativo ao nível de $20 \%$ e "ns" não significativo a um nível inferior a $20 \%$ ): 
para o 1º́período (1977-86)

$W T_{l}=\underset{(2,765) \mathrm{C}}{87,45} \pi-\underset{(-0,366) \mathrm{ns}}{0,0000025} P+\underset{(2,684) \mathrm{C}}{1,07} W M+\underset{(0,453) \mathrm{ns}}{0,61 P M O}$

para o $2^{\circ}$ período (1987-96)

$$
W T_{2}=-\underset{(-1,845) \mathrm{D}}{109,70} \pi-\underset{(-1,157) \mathrm{ns}}{0,0000035} P+\underset{(1,501) \mathrm{E}}{1,01} W M+\underset{(3,118) \mathrm{B}}{2,19} \mathrm{PMO}
$$

$\mathrm{R}^{2}=0,785 \quad \mathrm{n}=20 \quad \mathrm{DW}=2,017$ (inconclusivo) $\quad \mathrm{Q}(5-0)=5,831^{\mathrm{ns}}$

O teste Box-Pierce não demostra presença de autocorrelação residual mesmo ao nível de significância de $20 \%$.

Com intuito de captar a influência das variáveis independentes no comportamento dos salários dos trabalhadores rurais no Paraná fez-se os cálculos das elasticidades para as variáveis com nível de significância não superior a $20 \%$, com base na seguinte fórmula:

$\left.E_{x}=(\partial W / \partial X) \cdot \bar{X} / \bar{W}\right)$

Onde:

$X=$ variável independente em relação a qual se quer calcular a elasticidade;

$W$ = variável dependente, no caso os salários dos trabalhadores rurais no Paraná; e,

$\bar{X}$ e $\bar{W}=$ média das variáveis, calculadas separadamente para o primeiro e segundo períodos.

1ํoperíodo (1977-86):

$\mathrm{E}_{\pi}=0,32 \quad \mathrm{E}_{\mathrm{WM}}=0,59$ 
$2^{\circ}$ período (1987-96):

$\mathrm{E}_{\pi}=-0,43 \quad \mathrm{E}_{\mathrm{PMO}}=1,54 \quad \mathrm{E}_{\mathrm{WM}}=0,34$

Constata-se que, no primeiro período, um aumento de $1 \%$ no salário mínimo tem um efeito maior sobre o salário do tratorista em relação ao mesmo aumento no lucro do produtor rural. No segundo período, a produtividade da mão-deobra teve uma importância significativa na determinação do salário do tratorista, seguida do lucro e do salário mínimo.

Comparando-se as elasticidades do salário mínimo do $1^{\circ}$ e do $2^{\circ}$ período, verifica-se que esta é menor no segundo período, implicando menor influência desta variável na determinação do salário do tratorista entre 1987 a 1996 em relação ao período anterior (1977 a 1986).

Com relação aos determinantes do salário do tratorista conclui-se que:

a) o salário mínimo perde importância na sua determinação durante o $2^{0}$ periodo;

b) no $1^{\mathrm{o}}$ período o salário do tratorista caminhou no mesmo sentido do lucro dos produtores rurais no Paraná, o que não foi observado no $2^{\circ}$ período; e,

c) a produtividade da mão-de-obra teve um papel significativo no crescimento do salário do tratorista no segundo período.

\subsection{2- Determinantes do salário do mensalista (WMen)}

O modelo utilizado para a determinação do salário do mensalista é idêntico ao descrito para o caso do salário do tratorista (sendo ambas categorias consideradas como mão-de-obra permanente).

Como no caso do salário do tratorista, o comportamento do salário do mensalista também apresenta dois momentos distintos: decresce até 1987 e 
passa a crescer após este ano. Os determinantes destes comportamentos são objetivo de investigação deste item. Os dados utilizados para estimativa encontram-se na Tabela 2.2 do Apêndice 2.

Os resultados das estimativas do salário do mensalista para os dois períodos são (o valor entre parênteses abaixo dos coeficientes é a estatística " $t$ ", sendo " $\mathrm{B}$ " significativo a $1 \%$, "C" significativo a $5 \%$, " $\mathrm{D}$ " significativo a $10 \%$, "E" significativo a $20 \%$ e "ns" não foi significativo a um nivel inferior a $20 \%$ ):

\section{para o $1^{0}$ período (1977-86):}

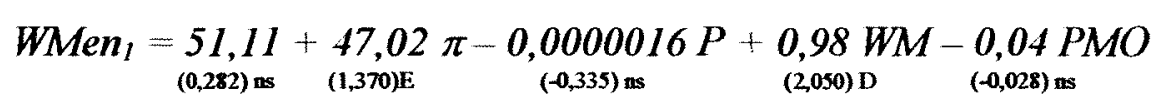

para $02^{\circ}$ período (1987-96):

$$
\begin{aligned}
& \mathrm{WMem}_{2}=\underset{(-1,554) \mathrm{E}}{-266,63}-\underset{(-0,958) \text { us }}{42,72} \pi \underset{(-2,485) \mathrm{C}}{0,0000063} P+\underset{(2,359) \mathrm{C}}{1,54} \mathrm{WM}+\underset{(3,075) \mathrm{C}}{3,14} \mathrm{PMO} \\
& \mathrm{R}^{2}=0,864 \quad \mathrm{n}=20 \quad \mathrm{~F}=7,040^{\mathrm{B}} \quad \mathrm{DW}=2,233 \text { (inconclusivo) } \quad \mathrm{Q}(5-0)=4,880^{\mathrm{ns}}
\end{aligned}
$$

Como o resultado do teste Durbin-Watson foi inconclusivo, fezse o teste Box-Pierce o qual não indica presença de autocorrelação nos resíduos.

Buscando um melhor ajuste do modelo excluí-se a constante ${ }^{22}$, obtendo-se o seguinte resultado (o valor entre parênteses abaixo dos coeficientes é a estatística " $t$ ", sendo: " $B$ " significativo a $1 \%$, " $C$ " significativo a $5 \%$, " $D$ " significativo a $10 \%$, "E" significativo a $20 \%$ e "ns" não foi significativo a um nível inferior a $20 \%$ ):

para o $1^{\circ}$ período $(1977-86)$ :

$$
\mathrm{WMen}_{1}=\underset{(2,352) \mathrm{c}}{54,31} \pi-\underset{(-0,389) \mathrm{ns}}{0,0000019} \mathrm{P}+\underset{(3,714) \mathrm{B}}{1,08} \mathrm{WM}+\underset{(0,224) \mathrm{ms}}{0,22} \mathrm{PMO}
$$

\footnotetext{
${ }^{22}$ As observações feitas anteriormente a respeito da exclusão da constante no caso do salário do tratorista fazem-se válidas, também. neste caso.
} 
para o $2^{\circ}$ período (1987-96):

$\mathrm{WMem}_{2}=\underset{(-1,165)}{-63,57} \pi-\underset{(-1,925) \mathrm{D}}{0,0000042} \mathrm{P}+\underset{(1,740) \mathrm{E}}{0,86} \mathrm{WM}+\underset{(3,430) \mathrm{B}}{1,76} \mathrm{PMO}$

$\mathrm{R}^{2}=0,829 \quad \mathrm{n}=20 \quad \mathrm{DW}=1,832$ (inconclusivo) $\quad \mathrm{Q}(5-0)=5,380^{\mathrm{ns}}$

O teste Box-Pierce indica que não há presença de autocorrelação

residual.

Calculando-se as elasticidades para as variáveis com nível de significância de até $20 \%$, obteve-se os seguintes resultados:

$1^{0}$ período (1977-86):

$\mathrm{E} \pi=0,26 \quad \mathrm{E}_{\mathrm{WM}}=0,79$

$2^{\circ}$ período (1987-96):

$\mathrm{E} \pi=-0,34 \quad \mathrm{E}_{\mathrm{P}}=-0,73 \quad \mathrm{E}_{\mathrm{WM}}=0,39 \quad \mathrm{E}_{\mathrm{PMO}}=1,69$

As elasticidades calculadas para o $1^{\circ}$ período demostram que uma variação de $1 \%$ no salário mínimo levaria a uma variação percentual maior no salário do mensalista em relação a idêntica variações no lucro. No $2^{o}$ período verifica-se que, considerando o nível de significância de $20 \%$, todas as variáveis são significativas e suas elasticidades demonstram a grande importância da produtividade da mão-de-obra na determinação do salário do mensalista, bem como a redução de importância do salário mínimo na determinação do salário do mensalista em relação ao período anterior.

Os sinais das elasticidades das variáveis lucro e produção total no segundo período são contrários ao esperado. No caso do sinal do lucro este fato também foi observado no caso do salário do tratorista.

Possiveis explicações para esses fenômenos são: 
a) a variável produção total considera somente o volume de produção agrícola. Não é esta a melhor medida. A variável ideal a ser considerada seria o PIB agropecuário, mas, não se dispõe de uma série completa que compreenda todo o período em análise; e,

b) o período entre 1987 e 1996 foi bastante turbulento para a economia brasileira, com os vários planos econômicos. Tais planos são variáveis externas que influenciaram diretamente o comportamento das variáveis especificadas no modelo.

\subsection{3- Determinantes do salário do trabalhador temporário (WV)}

Com relação ao salário do trabalhador temporário, considerou-se o salário do diarista. Conforme já foi visto, optou-se por considerar a "quebra" de tendência no ano de 1988. A equação utilizada na determinação do salário do diarista é a (21). Os dados utilizados para estimar a equação de determinação do salário do diarista encontram-se na Tabela 2.3 do Apêndice 2.

As estimativas das equações de determinação do salário do diarista encontram-se abaixo (onde os valores abaixo dos coeficientes referem-se as estatísticas " $t$ ", sendo: " $C$ " significativo a 5\%, "E" significativo a $20 \%$ e "ns" não significativo a um nível inferior a $20 \%$ ).

\section{1ำ período (1977-87)}

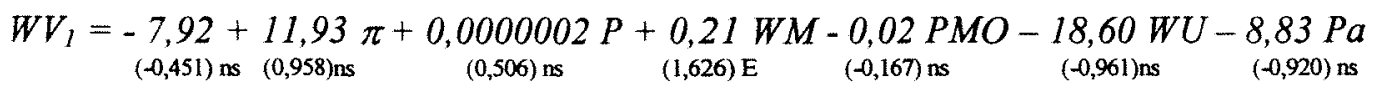

\section{$2^{0}$ período (1988-96)}

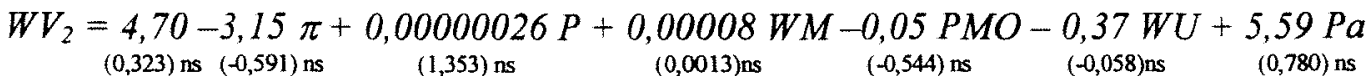

$$
\begin{aligned}
& \mathrm{R}^{2}=0,847 \quad \mathrm{n}=20 \quad \mathrm{~F}=2,555^{\mathrm{E}} \quad \mathrm{DW}=2,009 \text { (inconclusivo) } \quad \mathrm{Q}(5-0)=11,720^{\mathrm{C}}
\end{aligned}
$$


Como o teste Durbin-Watson foi inconclusivo, fez-se o teste Box-Pierce o qual indica presença de autocorrelação nos resíduos.

Pode-se verificar na equação (27b) que no segundo período, de 1988 a 1996, nenhum parâmetro estimado é estatisticamente diferente de zero, ao nível de $20 \%$ de significância. Objetivando melhorar a estimativa do modelo excluiu-se a constante $^{23}$ obtendo-se o seguinte resultado (onde os valores abaixo dos coeficientes referem-se as estatísticas " $t$ ", sendo: " $B$ " significativo a $1 \%$, " $D$ " significativo a $10 \%$ e "E" significativo a $20 \%$ e "ns" não significativo a um nível inferior a $20 \%$ ):

$1^{0}$ período (1977-87)

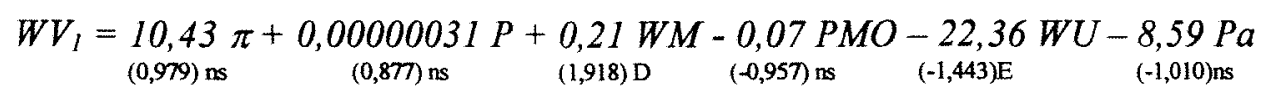

\section{$2^{\circ}$ período (1988-96)}

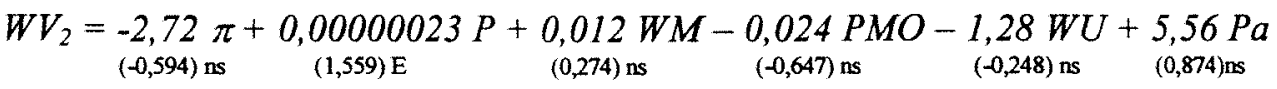

$$
\begin{aligned}
& \mathrm{R}^{2}=0,839 \quad \mathrm{n}=20 \quad \mathrm{DW}=1,956 \text { (inconclusivo) } \quad \mathrm{Q}(5-0)=16,920^{\mathrm{B}}
\end{aligned}
$$

O teste Box-Pierce indica problema de autocorrelação residual. Porém, o uso de variáveis artificiais inviabiliza a aplicação de rotinas visando corrigir tal problema. Fez-se novas estimativas buscando equações que apresentassem melhores resultados, em relação aos obtidos até então, utilizou-se dados em logaritmo e com “quebra" de tendência em 1987. No Apêndice 3 encontram-se os resultados obtidos, que não foram satisfatórios.

Com intuito de melhorar os resultados utilizou-se o método stepwise (para os dados sem logaritmo e mantendo a "quebra" de tendência no ano de 1988), o qual seleciona apenas as variáveis relevantes na explicação da variável

\footnotetext{
${ }^{23}$ As afirmações feitas para o salário do tratorista e do diarista são aqui também válidas.
} 
dependente, excluindo as variáveis cuja estatística $t$ estejam ruins. Com base neste método o modelo estimado ficou o seguinte (onde os valores abaixo dos coeficientes referem-se as estatísticas " $\mathrm{t}$ ", sendo: " $\mathrm{A}$ " significativo a $0,1 \%$, "C" significativo a $5 \%$. "D" significativo a $10 \mathrm{e}$ " $\mathrm{E}$ " significativo a $20 \%$ ):

\section{$1^{\circ}$ período (1977-87)}

$W V_{1}=\underset{(29,098) \mathrm{A}}{0,057} W M$

2 período (1988-96)

$$
\begin{aligned}
& W V_{2}=\underset{(2,331) \mathrm{C}}{0,00000026} \underset{(-1,356) \mathrm{E}}{0,035} \mathrm{PMO}+\underset{(2,333) \mathrm{C}}{4,04} \mathrm{~Pa} \\
& \mathrm{R}^{2}=0,779 \quad \mathrm{n}=20 \quad \mathrm{DW}=1,784 \text { (não hà autooorrelação residual) }
\end{aligned}
$$

Calculando as elasticidades do modelo gerado a partir do método setpwise, obtêm-se os seguintes resultados:

\section{1 período (1977-87):}

$E_{\text {wm }}=0,98$

\section{$2^{2}$ período (1988-96):}
$E_{P}=1,65$
$\mathrm{E}_{\mathrm{PMO}}=-1,08$
$\mathrm{E}_{\mathrm{Pa}}=0,66$

O cálculo das elasticidades demostra a importância do salário mínimo na determinação do salário do diarista no primeiro período. No segundo período a produção total teve um papel significativo na determinação do salário do diarista, onde um aumento de $1 \%$ na produção leva a um aumento de $1,65 \%$ no salário do diarista. A importância da produção total na determinação do salário do diarista vem ao encontro à afirmação de Bacha (1988) de que o trabalhador temporário suplementa o trabalhador permanente em periodos de maior demanda por trabalho. 
Com relação à elasticidade da variável produtividade da mão-deobra, esta apresentou sinal contrário ao esperado no segundo periodo. Acredita-se que este fato esteja relacionado ao avanço da modernização da agropecuária (que levou ao aumento da produtividade da mão-de-obra) passando-se a demandar mais trabalhadores com maior qualificação. Consequentemente, a demanda por trabalho menos qualificado, mão-de-obra temporária, reduz-se, implicando menores salários.

A elasticidade da variável que mede o índice de preços recebidos pelos pequenos proprietários rurais apresentou o sinal esperado. A influencia desta variável na determinação do salário do trabalhador temporário é menor que a influencia da produção e da produtividade da mão-de-obra. Um aumento de $1 \%$ nos preços recebidos, na produção e na produtividade da mão-de-obra levam a uma variação de $0,66 \%, 1,65 \%$ e $-1,08 \%$, respectivamente, no salário do diarista. 


\section{CONCLUSÃo}

Ocorreu no Paraná, nas últimas décadas, grande crescimento da produção agrícola e da agroindústria. No setor agrícola tem se destacado o trinômio soja/milho/trigo, que, em 1996, era responsável por $78 \%$ da área cultivada com as 14 principais culturas exploradas no Estado. Junto a isto, houve expressivo crescimento dos rebanhos de bovinos, suinos e aves.

No periodo de 1985 a 1995, verificou-se uma concentração de área em propriedades rurais de médio e grande portes e uma redução nas pequenas propriedades e nos latifúndios. Isto é compatível com a escala média adequada das propriedades agropecuárias que se dedicam às atividades predominantes no Estado.

Também no Paraná vem ocorrendo, há mais de duas décadas, redução da população rural. Simultaneamente, há queda de participação do subsetor agrícola na geração de empregos frente aos demais subsetores da agropecuária. Apesar disso, esta ainda é a principal geradora de empregos no meio rural, mesmo constatando que sua participação no número de pessoas ocupadas vem decrescendo.

Os dados do Censo Agropecuário de 1995/96 registraram a maior queda no emprego rural observada nos últimos tempos, $-30,59 \%$ entre 1985 e 1995 . Esta redução superou a diminuição no número de pessoas ocupadas na agropecuária na década de 70, em função da modernização então ocorrida na agropecuária paranaense. 
Com relação às categorias de pessoal ocupado na agropecuária paranaense, verifica-se a grande importância da agricultura familiar e dos trabalhadores não remunerados. Nos anos 90 , essas categorias responderam, juntas, por $57 \%$ do total do pessoal ocupado, de acordo com os microdados da PNAD.

A atividade que mais empregou nos anos 90 foi o milho, onde $o$ principal tipo de mão-de-obra ocupada foi o trabalhador por conta própria (agricultura familiar) e o trabalhador não remunerado, responsáveis, juntos, por $80 \%$ da mão-de-obra utilizada no cultivo do milho.

Verificou-se, com relação à qualificação da mão-de-obra ocupada nas atividades rurais, ligeiro aumento na participação da mão-de-obra qualificada e decréscimo na participação da mão-de-obra não qualificada, sinalizando, assim, a tendência de aumento da demanda por trabalhadores mais qualificados nas atividades agropecuánias.

As categorias de salários analisadas nesta pesquisa foram dos trabalhadores permanentes (tratorista e mensalista) e do trabalhador temporário (diarista). Com relação aos salários dos trabalhadores permanentes, observou-se uma "quebra" de tendência no ano de 1987. Os salários desta categoria apresentaram tendência de queda entre 1977 a 1987 e de crescimento no periodo 1988 a 1996. Esta "quebra" de tendência ficou evidenciada através dos ajustes feitos das funções poligonais para o salário do tratorista e do mensalista. No caso do salário do trabalhador temporário a "quebra" de tendência ocorreu um ano depois, em 1988.

Por outro lado, verificou-se que o salário mínimo apresentou a maior queda no período em análise. Ademais, constatou-se que a base salarial do trabalhador permanente (em termos de salários mínimos) aumentou.

Com o Plano Real e a estabilização da moeda na economia brasileira, o salário do mensalista manteve-se constante em termos de salário mínimo. $\mathrm{O}$ 
periodo de maior aumento nos salários dos trabalhadores permanentes em relação ao salário mínimo deu-se entre 1987 e 1993, ou seja, em um período de inflação elevada e de vários planos de estabilização dos preços.

Com relação aos determinantes dos salários dos trabalhadores rurais, modificou-se o modelo proposto inicialmente para determinação dos salários destes, de modo a incorporar a "quebra" de tendência. Com isso, tem-se duas equações de determinação dos salários: uma para o período de 1977 a 1986 e outra para o período de 1987 a 1996 para os trabalhadores permanentes. Para os trabalhadores temporários, em função de "quebra" de tendência ter-se dado no ano de 1988, as equações estimadas correspondem aos períodos de 1977 a 1987 e de 1988 a 1996.

Os principais determinantes dos salários dos trabalhadores permanentes no $1^{\mathrm{o}}$ período $(1977 / 86)$ são o lucro e o salário mínimo. E os cálculos das elasticidades demostram a maior importância do salário mínimo na determinação dos salários dos trabalhadores permanentes (tratorista e mensalista) em relação ao lucro.

No segundo período (1987/96) os principais determinantes dos salário do tratorista foram a produtividade da mão-de-obra, o salário mínimo e o lucro. Para o caso do mensalista além dos determinantes acima incluiu-se também a variável produção total. Os cálculos das elasticidades demostraram a importância da produtividade da mão-de-obra na determinação dos salários dos tratoristas e mensalistas no $2^{\underline{o}}$ periodo, e a diminuição de importância do salário mínimo na determinação do salário do trabalhador permanente no segundo periodo.

Para o trabalhador temporário o principal determinante do seu salário foi, no primeiro período (1977 a 1987), o salário mínimo. No segundo período (1988 a 1996) os cálculos das elasticidades demonstraram a maior importância da produção total e da produtividade na mão-de-obra da determinação do salário do diarista. Os preços recebidos pelos pequenos produtores, também, influenciaram positivamente o salário do diarista. 
A constatação de que a produtividade da mão-de-obra tem sido, nos últimos anos, importante determinante dos salários torna necessárias políticas voltadas ao investimento em capital humano, tais como: atividades de extensão rural e melhoria do ensino fundamental na zona rural. Tais atitudes são essenciais para adequar a mão-de-obra rural ao avanço da modernização nas atividades agropecuárias.

O presente trabalho não esgota o assunto relacionado a emprego e salário dos trabalhadores agropecuários no Paraná. Outros trabalhos poderão ser realizados buscando evidenciar quais os fatores responsáveis pela grande utilização de mão-de-obra não remunerada nas atividades agropecuárias. Necessita-se, também, de estudos mais aprofundados que busquem apontar as causas da grande redução no número de pessoas ocupadas na agropecuária paranaense nos anos compreendidos entre $1985 \mathrm{e}$ 1995. Trabalhos futuros poderão analisar o comportamento dos salários de outras categorias de trabalhadores rurais no Paraná, no Brasil e nos demais Estados. 


\begin{abstract}
ANEXO A
Gráficos com evolução e tendência das variáveis utilizadas para estimativa das equações de determinação dos salários dos trabalhadores na agropecuária do paraná .
\end{abstract}




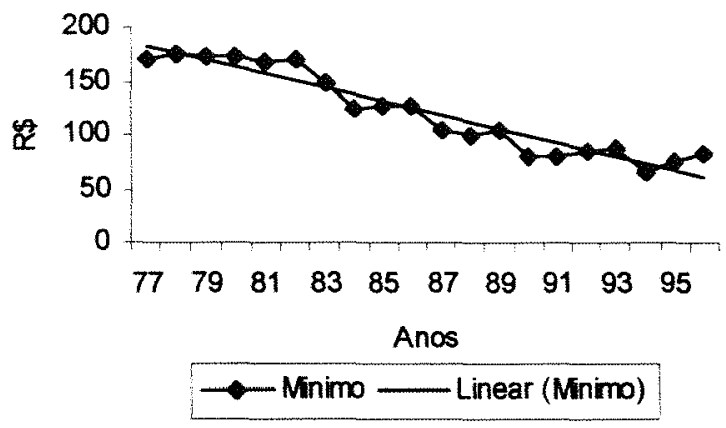

Figura A1 Evolução do salário minimo no Brasil, 1977-96

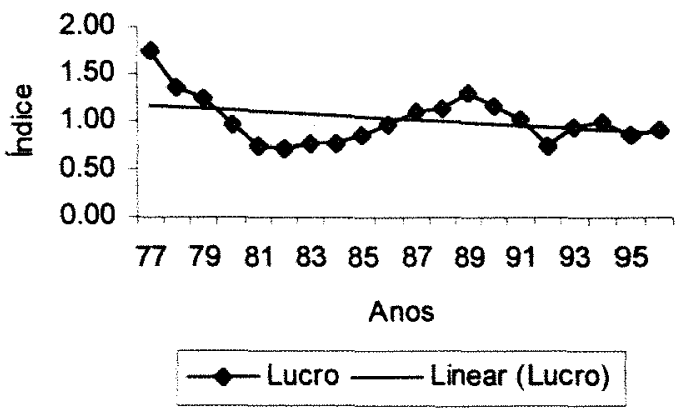

Figura A3 Evolução do lucro (relação de preços recebidos/ pagos) dos produtores rurais do Paraná, 197796.

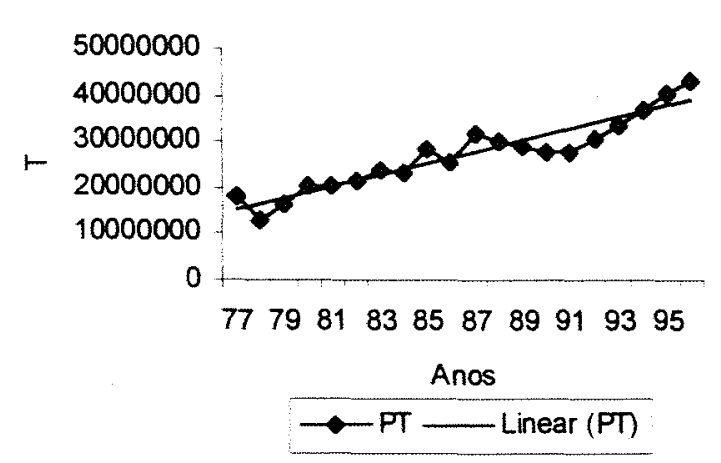

Figura A5 Evolução da produção total (T) na agricultura paranaense, 1977-96.

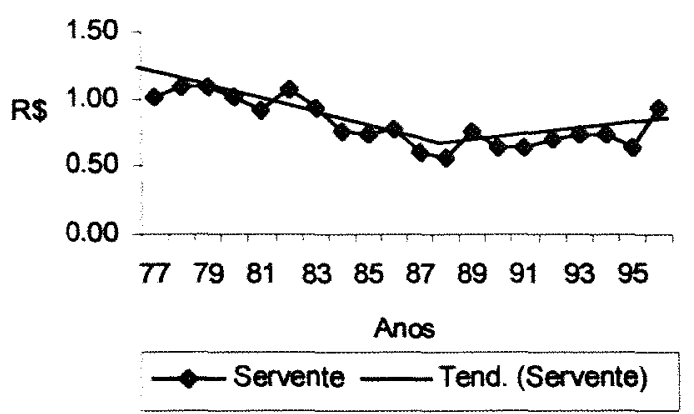

Figura A2 Evolução do salário dos serventes na indústria da construção civil em são Paulo, 1977-96

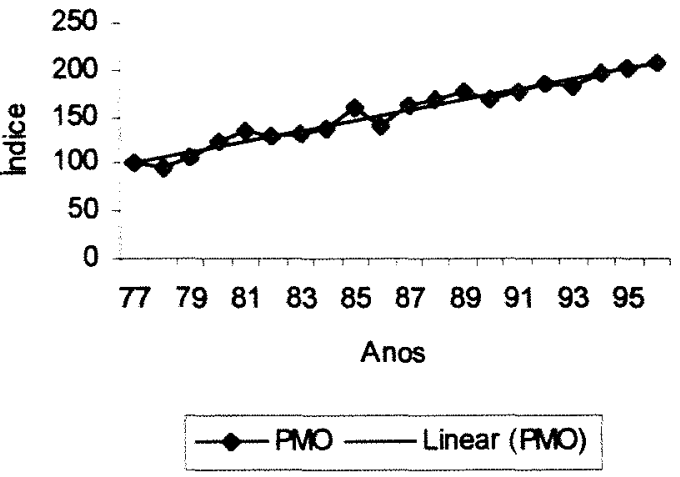

Figura A4 Evolução da produtividade da mão-de-obra na agricultura brasileira, 1977-96.

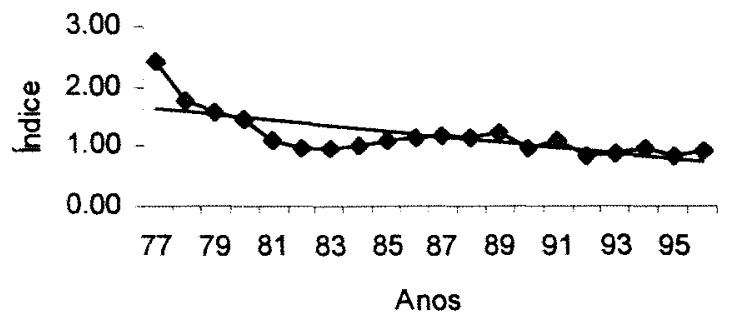

$\longrightarrow$ Pç. recebido — Linear (Pç. recebido)

Figura A6 Evolução do índice de preços recebidos pelos produtores rurais no Paraná, 1977-96. 


\section{BIBLIOGRAFIA}

ACOMPANHAMENTO DA SITUAÇÃO AGROPECUÁRIA DO PARANÁ, Curitiba,SEAB-DERAL 1980-1997 (vários meses)

AGUIRRE, B. M. B.; BACHA, C. J. C. Mercado de trabalho rural e suas perspectivas. ESALQ/FEALQ/Banco Mundial, São Paulo: 1989a. (Relatório do pesquisa)

AGUTRRE, B. M. B.; BACHA, C. J. C. A especialização da mão-de-obra rural no Brasil. n: CONGRESSO BRASILEIRO DE ECONOMIA E SOCIOLOGIA RURAL, n.27, Piracicaba, 1989. Anais. Brasilia: SOBER, 1989 b. v.1, p.572-584.

ALBUQUERQUE, C.A.C. Desafios do Paraná. Revista Paranaense de Desenvolvimento, n.86, p. 35-47, set./dez. 1995.

ALVES, Eliseu. Tecnologia e emprego. Revista de Política Agrícola, ano 6, n.1, jan./mar.1997.

ANÁLISE CONJUNTURAL. Curitiba, v.17, n. 1-2, p. 39-40, jan/fev. 1995.

ANÁLISE CONJUNTURAL. Curitiba, v.18, nº 3-4, p. 51, mar/abr., 1996.

ANUÁRIO ESTATÍSTICO DO BRASIL. Rio de Janeiro, 1977-1996 (vários anos).

BACHA, C.J.C. Evolução recente da cafeicultura mineira: determinantes e impactos. São Paulo, 1988. 536 p. Tese (Doutorado)- Faculdade de Economia e Administração, Universidade de São Paulo.

BACHA, C.J.C. Determinação dos salários na agricultura. Revista Brasileira de Economia, v.45, n. 3, p.441-471, jul./set. 1991.

BALSADI, O.V. Condicionantes da renda das pessoas ocupadas na agricultura paulista em 1981 e 1990. Informações Econômicas, v.26, n.8, p.41-47, ago.1996. 
BANCO MUNDIAL. Relatório sobre o desenvolvimento mundial. Washington, 1996.

CAMPOS, A. C. Escolaridade e suas implicações no mercado de trabalho rural no estado do Paraná, 1970 e 1980. Piracicaba, 1998. 107 p. Dissertação (MS) -Escola Superior de Agricultura "Luiz de Queiroz", Universidade de São Paulo.

CARVALHO, D. Mercado de trabalho na agricultura brasileira: década dos oitenta. Piracicaba, 1993. 160p. Dissertação (Mestrado) - Escola Superior de Agricultura "Luiz de Queiroz”, Universidade de São Paulo.

CENSO AGROPECUÁRIO: Paraná. 1970. Rio de Janeiro, v. 3, tomo 9, 1970

CENSO AGROPECUÁRIO: Paraná. 1975. Rio de Janeiro, v.1, tomo 18, $1^{\mathrm{a}}$ parte, 1979.

CENSO AGROPECUÁRIO: Paraná. 1980. Rio de Janeiro, v.2, tomo 3, n.20, $1^{\text {a }}$ parte, 1980.

CENSO AGROPECUÁRIO: Paraná. 1985. Rio de Janeiro, n. 22.

CENSO AGROPECUÁRIO: Paraná. 1995/96. Rio de Janeiro. n. 20

CENSO DEMOGRÁFICO: Mão-de-obra: Paraná. 1970. Rio de Janeiro, v. 1, tomo 9,1970 .

CENSO DEMOGRÁFICO: Mão-de-obra: Paraná. 1980. Rio de Janeiro, v. 1, tomo 5, n.20, 1980 .

CENSO DEMOGRÁFICO: Mão-de-obra: Paraná. 1991. Rio de Janeiro, 1991. n. 22.

CONJUNTURA ECONÔMICA. Rio de Janeiro: Fundação Getúlio Vargas, 1977-1998 (diversos meses).

CONTAGEM DA POPULAÇÃO: Resultados Relativos a Sexo da População e Situação da Unidade Domiciliar. 1996. Rio de Janeiro. v. 1. 1997. 
CORRÊA, Angela M.C.J.. Distribuição de rendimentos e pobreza na agricultura brasileira: 1981-1990. Piracicaba, 1995. 353p. Tese. Escola Superior de Agricultura “Luiz de Queiroz" - Universidade de São Paulo.

CUNHA, A.S., MAIA, M.M. Modernização tecnológica e emprego rural: evidências da década de 70 na Região Centro-Sul do Brasil. In: CONFERÊNCIA LATINOAMERICANA DE ECONOMIA AGRÍCOLA, Piracicaba, 1984. Trabalhos v.3, p.1-53.

DEUS, V.L.F. Bovinos de corte. In: Acompanhamento da Situação Agropecuária do Paraná. V. $23 \mathrm{n}^{\circ} 2$, fev/97.

ESTATÍSTICAS BÁSICAS: Indicadores da Produção Agroindustrial 1971-93 Rio de Janeiro, Séries retrospectivas, n. 4

FERreirA, A. B. de Holanda. Dicionário Aurélio Básico de Língua Portuguesa. Rio de Janeiro: Nova Fronteira S/A, 1994/95.

FONSECA, M.G.D.; GONÇALVES, J.S. Financiamento do investimento da agroindústria e agropecuária: análise de dois planos governamentais recentes. Informações Econômicas, v.25, n.6, jun.1995.

GASQUES, J.G. Oferta e demanda de mão-de-obra volante no Estado de São Paulo. Piracicaba, 1975, 163 p. Dissertação (Mestrado) - Escola Superior de Agricultura "Luiz de Queiroz", Universidade de São Paulo.

GASQUES, J.G. \& CONCEIÇÃO, J.C.P.R. Crescimento e produtividade da agricultura brasileira. Texto para discussão. IPEA, n. 502 . Julho 1997 p. 7-21. 
GISSER, M. Escolaridade e o problema da empresa agrícola. IN: ARAÚJO P.F.C. \& SCHUH, G.E. Desenvolvimento da agricultura: educação, pesquisa e assistência técnica. São Paulo, 1975. P. 3-15.

GONÇALVES, J.S. Salário, emprego, modernização e sazonalidade na agropecuária: as condições do processo excludente do desempenho brasileiro. Informações Econômicas, v.26, n.1, p.23-37, jan.1996.

GROSSI, M.E.D. Transformações no meio rural paranaense. In: CONGRESSO BRASILEIRO DE ECONOMIA E SOCIOLOGIA RURAL, n.34, Campinas, 1996. Anais. Brasilia: SOBER, 1996. v.1, p. 51-70.

GUERREIRO, E. Produtividade do trabalho e da terra na agropecuária paranaense. Piracicaba, 1995, 136 p. Dissertação (Mestrado) - Escola Superior de Agricultura "Luiz de Queiroz", Universidade de São Paulo.

HESPANHOL, A. N.; COSTA, V. M. H. M. A intensificação do processo produtivo agrícola no estado do Paraná. In: CONGRESSO BRASILEIRO DE ECONOMIA E SOCIOLOGIA RURAL n.32, Brasília, 1994. Anais. Brasília: SOBER, 1994. v.2, p. 1064.

HOFFMANN, R. Vinte anos de desigualdade e pobreza na agricultura brasileira. Revista de Economia e Sociologia Rural, v.30,n.2,p.97-113, abr./jun.,1992.

HOFFMANN R \& VIERA, S. Análise de Regressão, uma introdução à econometria. São Paulo, HUCITEC, 1987, 378 p.

IPARDES. Conseqüências sociais das transformações tecnológicas na agricultura do Paraná. Curitiba, ago. 1981 a.

IPARDES. Mercado de trabalho agrícola do Paraná. Curitiba, 1981 b.

IPARDES. O Paraná Economia e Sociedade, Curitiba, 1982. 
IPARDES. Análise do emprego no Paraná. Curitiba. fev. 1983.

IPARDES. Base de dados acessado via INTERNET, endereço: IPARDES.GOV.BR

ISTAKE, M. Comportamento do emprego na Paraná, 1970-85. Maringá: (Universidade Estadual de Maringá) 1992. (Monografia).

JORGENSON, D.W. Teste de teorias alternativas de desenvolvimento em economia dualista. In: ARAÚJO P.F.C. \& SCHUH G.E. Desenvolvimento da agricultura: natureza do processo e modelos dualistas. São Paulo: Pioneira, 1975. P. 137-152.

KAGEYAMA, A.; REHDER, P. O bem-estar rural no Brasil na década de oitenta. Revista de Economia e Sociologia Rural, v.31, n.1, p. 23-44. jan/mar. 1993.

KONZEN, O.G.;ZAPPAROLI, I.D. Estrutura agrária e capitalização da agricultura no Paraná. Revista de Economia e Sociologia Rural. v.28, n.4, out./dez. 1990.

LEÃO, I.Z.C.C. Os anos 80 e o Paraná. Análise Conjuntural. IPARDES, v. 13, n. 7-8, p.17, jul./ago 1991.

LORENÇO, G.M. Perspectivas para a atividade cafeeira brasileira e paranaense em 1995.. Análise Conjuntural. IPARDES, v.17, n.1-2, p. 15, jan./fev. 1995 a.

LORENÇO, G.M. Expansão recente da economia paranaense: componentes estruturais e conjunturais., Análise Conjuntural. IPARDES, v.17, n. 3-4, p.20, mar./abr. 1995b.

LORENÇO, G. M. Produção industrial paranaense-retrospecto do primeiro semestre de 1995 e perspectivas.. Análise Conjuntural. IPARDES v. 17, n. 7-8, p.18, jul./ago. $1995 \mathrm{c}$.

MAGAlHÃES FILHO, F. de B. B. O Paraná em revista. Revista Paranaense de Desenvolvimento, n.82, p. 5-16, maio/ago. 1994. 
MARTINE, G.;ARIAS, A.R.. A Evolução do emprego no campo. In: Revista Brasileira de Estudos de População. Pg. 39-84, jul./dez., 1987. V.4 n.2.

MARTINS, R.S.; MASSOLA, M.P. A dinâmica da agricultura paranaense nos anos 70 e 80: o caso das culturas de verão. Revista de Economia e Sociologia Rural, v.32, n.3, p.305-321, jul./set. 1994.

MARTINS, R.S.; MASSOLLA, M.P. O desempenho da agricultura paranaense nos anos 90: o caso das culturas de verão. In: CONGRESSO BRASILEIRO DE ECONOMIA E SOCIOLOGIA RURAL, n. 33, Curitiba, 1995. Anais. Brasília: SOBER, 1995. v.1 p. 391-405.

MUELLER, C.C. A evolução recente da agropecuária brasileira segundo dados dos Censos Agropecuários. In: IPEA Análise dos Censos Agropecuários de 1985. Brasilia, 1987, p. 11-41.

NOJMA, D. Considerações sobre produtividade e geração de empregos na indústria paranaense nos anos recentes. Análise Conjuntural. IPARDES. v.17, n.11-12, p.9 nov./dez 1995.

NOJMA, D. A competitividade do desenvolvimento agroindustrial no Estado. Análise conjuntural. IPARDES, v.18, n.7-8, p.14, jul./ago. 1996.

OLIVEIRA, C.A.B. Quinze anos depois. Revista Paranaense de Desenvolvimento, n. 83 p. $5-15$, set/dez 1994.

PADIS, P.C. Formação de uma economia periférica: o caso do Paraná, São Paulo: HUCITEC, 1981, $235 \mathrm{p}$.

PAULA, N.M.; DOMAKOSKY, L.A.; REIS, O.J.R. de S. Competitividade da indústria paranaense: uma análise setorial. Análise Conjuntural. IPARDES. v. 17, n.3-4, p.29, mar/abr, 1995. 
PEREIRA, L.B; LUGNANI, A.C. Novos rumos da agricultura paranaense na década de 80. Estudos Econômicos, v.21, n.3, p. 351-378, set./dez. 1991.

PEREIRA, L.B. O estado e o desempenho da agricultura paranaense no período de 1975-85. Revista de Economia e Sociologia Rural, v.30, n.2, p. 115-133, abr./jun. 1992.

PEREIRA, L.B. Análise da estrutura produtiva e desempenho da agroindústria paranaense- período 1970-85. Revista de Economia e Sociologia Rural, v.32,n.2, nov./dez 1995.

PESQUISA NACIONAL POR AMOSTRA DE DOMICÍLIO. 1990. Rio de Janeiro: IBGE, (diversos anos).

PRODUÇÃO AGRÍCOLA MUNICIPAL. 1970. Rio de Janeiro: IBGE, v.6, tomo 6, 1970

PRODUÇÃO AGRÍCOLA MUNICIPAL. 1980. Rio de Janeiro: IBGE, v.7, tomo. 6, 1980.

RICHTER, G.O. Rebanho suíno no Paraná In: Acompanhamento da Situação Agropecuária do Paraná. V. 23 nº 2, fev/97.

RIZZI, A.; URBAN, M.L. Restruturação industrial e seus reflexos na indústria agroalimentar. Análise Conjuntural. IPARDES, v. 13, n. 9-10, st/out., 1991.

ROLIM, C.F.C. O Paraná urbano e o Paraná do agrobusiness: as dificuldades para formulação de um projeto político. Revista Paranaense de Desenvolvimento, n. 86, p. 49-99, set./dez. 1995.

SENAVER, B.; ASP, E.; KINSEY, Jean. Food Trends and the changing consumer. Minnessota: Eagan Press, 1993. 
SILVA, B.O.; CONSIDERA, C.M. et al. Produto Interno Bruto por unidade da federação. Texto para discussão. IPEA, n. 424, maio 1996 p. 1-105.

SILVA, J.G.; KAGEYAMA, A. A. Como mudou o emprego no campo. Reforma Agrária, v.12, n.3, p. 67-70. maio/jun. 1982.

SLLVA, J.G.; KAGEYAMA, A. A. Pessoal ocupado na agricultura, 1970-80. Reforma Agrária, v. 13, n. 1-2, p. 40-42, jan./abr. 1983 a.

SILVA, J.G.; KAGEYAMA, A. A. Emprego e relações de trabalho na agricultura brasileira: uma análise dos dados censitários de 1960, 70 e 75. Pesquisa e Planejamento Econômico, v.13, n.1, p. 235-266, abr. 1983 b.

SILVA, J. G. Pessoal ocupado: alguns resultados preliminares do censo agropecuário de 1985. In: IPEA. Análise dos dados do Censo Agropecuário de 1985. Brasília: IPEA, 1987.p. 42-62.

SILVA, J. G. O novo rural brasileiro. In: ENCONTRO NACIONAL DE ECONOMIA. Campinas, n. 24,1996. Anais. São Paulo: ANPEC, 1996. v. 3, p. 345-361.(a)

SILVA, J.G. A estrutura agrária do Estado do Paraná. Revista Paranaense de Desenvolvimento. n.87 p. 175-195, jan./abr. 1996 (b)

SILVA, J. G. A nova Dinâmica da Agricultura Brasileira. Campinas: Instituto de Economia, 1987 UNICAMP.217 p.

SILVA, N. de D. V. Mercado de trabalho formal e informal: uma análise da discrição e da segmentação. Piracicaba, 1997. 125p. Dissertação (M.S.)- Escola Superior de Agricultura "Luiz de Queiroz", Universidade de São Paulo.

SUZUKI JUNIOR, J.T. A expansão do setor avícola no Paraná e no Brasil. Análise Conjuntural. IPARDES, Curitiba. v.17 n. 9-10, p.12, set./out. 1995. 
WANDERLEY, S. de A. A recuperação da citricultura no noroeste do Paraná observações iniciais. Análise Conjuntural. IPARDES, v. 16, n.9-10, set./dez 1994.

ZANCHET, M.S. Emprego Rural no Paraná: situação recente e perspectivas. Análise Conjuntural, IPARDES, v.18, n 11-12, p.22-24, nov./dez 1996. 


\section{APÊNDICE 1}

Dados utilizados na estimativas da tendência dos salários na agropecuária do Paraná. 
Tabela 1.1 Dados utilizados para a estimativa da tendência dos salários dos trabalhadores nas atividades agrícola no Paraná, 1977-96.

\begin{tabular}{|c|c|c|c|c|c|c|c|}
\hline \multirow[b]{2}{*}{ Anos } & \multicolumn{4}{|c|}{ Trabalhadores permanentes } & \multicolumn{3}{|c|}{ Trabalhador temporário } \\
\hline & Wmen & WT & V & W & WV & $\mathrm{V}$ & W \\
\hline 77 & 278,10 & 356,99 & -10 & 0 & 10,27 & -11 & 0 \\
\hline 78 & 265,00 & 344,25 & -9 & 0 & 9,53 & -10 & 0 \\
\hline 79 & 231,37 & 309,07 & -8 & 0 & 8,99 & -9 & 0 \\
\hline 80 & 217,81 & 269,86 & -7 & 0 & 9,52 & -8 & 0 \\
\hline 81 & 212,88 & 274,20 & -6 & 0 & 10,39 & -7 & 0 \\
\hline 82 & 227,69 & 303,94 & -5 & 0 & 10,12 & -6 & 0 \\
\hline 83 & 186,96 & 244,13 & -4 & 0 & 8,12 & -5 & 0 \\
\hline 84 & 174,58 & 219,10 & -3 & 0 & 5,97 & -4 & 0 \\
\hline 85 & 162,20 & 238,28 & -2 & 0 & 7,18 & -3 & 0 \\
\hline 86 & 167,14 & 261,17 & -1 & 0 & 8,53 & -2 & 0 \\
\hline 87 & 141,98 & 200,02 & 0 & 0 & 8,47 & -1 & 0 \\
\hline 88 & 190,16 & 239,13 & 0 & 1 & 5,27 & 0 & 0 \\
\hline 89 & 212,21 & 269,65 & 0 & 2 & 6,06 & 0 & 1 \\
\hline 90 & 184,18 & 241,22 & 0 & 3 & 5,52 & 0 & 2 \\
\hline 91 & 190,68 & 260,27 & 0 & 4 & 6,54 & 0 & 3 \\
\hline 92 & 212,48 & 290,98 & 0 & 5 & 5,50 & 0 & 4 \\
\hline 93 & 200,25 & 274,42 & 0 & 6 & 4,88 & 0 & 5 \\
\hline 94 & 153,45 & 215,67 & 0 & 7 & 4,84 & 0 & 6 \\
\hline 95 & 201,96 & 292,97 & 0 & 8 & 8,06 & 0 & 7 \\
\hline 96 & 216,18 & 319,17 & 0 & 9 & 7,89 & 0 & 8 \\
\hline
\end{tabular}




\section{APÊNDICE 2}

Dados utilizados para estimar as equações de determinação do salário dos trabalhadores permanentes e temporários na agropecuária paranaense. 
Tabela 2.1 Dados utilizados para estimativa da equação de determinação do salário do tratorista no Paraná, 1977 a 1996.

\begin{tabular}{rccccccccccc}
\hline Anos & WT & Cte $_{1}$ & $\mathrm{Cte}_{2}$ & $\Pi_{1}$ & $\Pi_{2}$ & $\mathrm{P}_{1}$ & $\mathrm{P}_{2}$ & $\mathrm{WM}_{1}$ & $\mathrm{WM}_{2}$ & $\mathrm{PMO}_{1}$ & $\mathrm{PMO}_{2}$ \\
\hline 1977 & 356,99 & 1 & 0 & 1,76 & 0 & 18072402 & 0 & 171,27 & 0 & 100,00 & 0 \\
78 & 344,25 & 1 & 0 & 1,35 & 0 & 13345690 & 0 & 175,44 & 0 & 96,00 & 0 \\
79 & 309,07 & 1 & 0 & 1,24 & 0 & 16476686 & 0 & 173,44 & 0 & 105,58 & 0 \\
80 & 269,86 & 1 & 0 & 0,98 & 0 & 20394120 & 0 & 172,13 & 0 & 122,58 & 0 \\
81 & 274,20 & 1 & 0 & 0,76 & 0 & 20277878 & 0 & 168,10 & 0 & 133,76 & 0 \\
82 & 303,94 & 1 & 0 & 0,72 & 0 & 21522969 & 0 & 171,80 & 0 & 130,15 & 0 \\
83 & 244,13 & 1 & 0 & 0,79 & 0 & 24119071 & 0 & 149,00 & 0 & 131,57 & 0 \\
84 & 219,10 & 1 & 0 & 0,77 & 0 & 23036377 & 0 & 124,20 & 0 & 137,23 & 0 \\
85 & 238,28 & 1 & 0 & 0,86 & 0 & 28182717 & 0 & 125,87 & 0 & 159,85 & 0 \\
86 & 261,17 & 1 & 0 & 0,98 & 0 & 25326018 & 0 & 127,24 & 0 & 140,63 & 0 \\
87 & 200,02 & 0 & 1 & 0 & 1,10 & 0 & 31612516 & 0 & 105,01 & 0 & 162,45 \\
88 & 239,13 & 0 & 1 & 0 & 1,14 & 0 & 30186561 & 0 & 101,20 & 0 & 169,53 \\
89 & 269,65 & 0 & 1 & 0 & 1,32 & 0 & 29161824 & 0 & 104,86 & 0 & 178,25 \\
90 & 241,22 & 0 & 1 & 0 & 1,18 & 0 & 27832022 & 0 & 80,18 & 0 & 168,57 \\
91 & 260,27 & 0 & 1 & 0 & 1,04 & 0 & 27930217 & 0 & 79,83 & 0 & 175,60 \\
92 & 290,98 & 0 & 1 & 0 & 0,75 & 0 & 30959890 & 0 & 85,45 & 0 & 184,43 \\
93 & 274,42 & 0 & 1 & 0 & 0,94 & 0 & 33577720 & 0 & 88,55 & 0 & 181,25 \\
94 & 215,67 & 0 & 1 & 0 & 1,01 & 0 & 36689718 & 0 & 67,06 & 0 & 197,21 \\
95 & 292,97 & 0 & 1 & 0 & 0,85 & 0 & 40545785 & 0 & 76,29 & 0 & 201,88 \\
96 & 319,17 & 0 & 1 & 0 & 0,91 & 0 & 43306941 & 0 & $\mathbf{8 2 , 6 9}$ & 0 & 207,49 \\
\hline
\end{tabular}

Fonte: Descritas na metodologia . 
Tabela 2.2 Dados utilizados para estimativa da equação de determinação do salário do mensalista no Paraná, 1977 a 1996.

\begin{tabular}{rccccccccccc}
\hline Anos & Wmen & $\mathrm{Cte}_{1}$ & $\mathrm{Ct}_{2}$ & $\Pi_{1}$ & $\Pi_{2}$ & $\mathrm{P}_{1}$ & $\mathrm{P}_{2}$ & $\mathrm{WM}_{1}$ & $\mathrm{WM}_{2}$ & $\mathrm{PMO}_{1}$ & $\mathrm{PMO}_{2}$ \\
\hline $\mathbf{7 7}$ & 278,10 & 1 & 0 & 1,76 & 0 & 18072402 & 0 & 171,27 & 0 & 100,00 & 0 \\
78 & 265,00 & 1 & 0 & 1,35 & 0 & 13345690 & 0 & 175,44 & 0 & 96,00 & 0 \\
79 & 231,37 & 1 & 0 & 1,24 & 0 & 16476686 & 0 & 173,44 & 0 & 105,58 & 0 \\
80 & 217,81 & 1 & 0 & 0,98 & 0 & 20394120 & 0 & 172,13 & 0 & 122,58 & 0 \\
81 & 212,88 & 1 & 0 & 0,76 & 0 & 20277878 & 0 & 168,10 & 0 & 133,76 & 0 \\
82 & 227,69 & 1 & 0 & 0,72 & 0 & 21522969 & 0 & 171,80 & 0 & 130,15 & 0 \\
83 & 186,96 & 1 & 0 & 0,79 & 0 & 24119071 & 0 & 149,00 & 0 & 131,57 & 0 \\
84 & 174,58 & 1 & 0 & 0,77 & 0 & 23036377 & 0 & 124,20 & 0 & 137,23 & 0 \\
85 & 162,20 & 1 & 0 & 0,86 & 0 & 28182717 & 0 & 125,87 & 0 & 159,85 & 0 \\
86 & 167,14 & 1 & 0 & 0,98 & 0 & 25326018 & 0 & 127,24 & 0 & 140,63 & 0 \\
87 & 141,98 & 0 & 1 & 0 & 1,10 & 0 & 31612516 & 0 & 105,01 & 0 & 162,45 \\
88 & 190,16 & 0 & 1 & 0 & 1,14 & 0 & 30186561 & 0 & 101,20 & 0 & 169,53 \\
89 & 212,21 & 0 & 1 & 0 & 1,32 & 0 & 29161824 & 0 & 104,86 & 0 & 178,25 \\
90 & 184,18 & 0 & 1 & 0 & 1,18 & 0 & 27832022 & 0 & 80,18 & 0 & 168,57 \\
91 & 190,68 & 0 & 1 & 0 & 1,04 & 0 & 27930217 & 0 & 79,83 & 0 & 175,60 \\
92 & 212,48 & 0 & 1 & 0 & 0,75 & 0 & 30959890 & 0 & 85,45 & 0 & 184,43 \\
93 & 200,25 & 0 & 1 & 0 & 0,94 & 0 & 33577720 & 0 & 88,55 & 0 & 181,25 \\
94 & 153,45 & 0 & 1 & 0 & 1,01 & 0 & 36689718 & 0 & 67,06 & 0 & 197,21 \\
95 & 201,96 & 0 & 1 & 0 & 0,85 & 0 & 40545785 & 0 & 76,29 & 0 & 201,88 \\
96 & 216,18 & 0 & 1 & 0 & 0,91 & 0 & 43306941 & 0 & 82,69 & 0 & 207,49 \\
\hline
\end{tabular}

Fontes: descritas na metodologia. 
Tabela 2.3 Dados utilizados para estimativa da equação de determinação do salário do diarista no Paraná, 1977 a 1996.

\begin{tabular}{|c|c|c|c|c|c|c|c|c|c|c|c|c|c|c|c|}
\hline Anos & WV & $\mathrm{Cte}_{1}$ & $\mathrm{Cte}_{2}$ & $\pi_{1}$ & $\pi_{2}$ & $P_{1}$ & $\mathrm{P}_{2}$ & $\mathrm{WM}_{1}$ & $W_{2}$ & $\mathrm{PMO}_{1}$ & $\mathrm{PMO}_{2}$ & $\mathrm{WU}_{1}$ & $\mathrm{WU}_{2}$ & $P a_{1}$ & $\mathrm{~Pa}_{2}$ \\
\hline 77 & 10,27 & 1 & 0 & 1,76 & 0 & 18.072 .402 & 0 & 171,27 & 0 & 100,00 & 0 & 1,01 & 0 & 2,40 & 0 \\
\hline 78 & 9,53 & 1 & 0 & 1,35 & 0 & 13.345 .690 & 0 & 175,44 & 0 & 96,00 & 0 & 1,08 & 0 & 1,78 & 0 \\
\hline 79 & 8,99 & 1 & 0 & 1,24 & 0 & 16.476 .686 & 0 & 173,44 & 0 & 105,58 & 0 & 1,09 & 0 & 1,59 & 0 \\
\hline 80 & 9,52 & 1 & 0 & 0,98 & 0 & 20.394 .120 & 0 & 172,13 & 0 & 122,58 & 0 & 1,01 & 0 & 1,43 & 0 \\
\hline 81 & 10,39 & 1 & 0 & 0,76 & 0 & 20.277 .878 & 0 & 168,10 & 0 & 133,76 & 0 & 0,92 & 0 & 1,09 & 0 \\
\hline 82 & 10,12 & 1 & 0 & 0,72 & 0 & 21.522 .969 & 0 & 171,80 & 0 & 130,15 & 0 & 1,07 & 0 & 0,97 & 0 \\
\hline 83 & 8,12 & 1 & 0 & 0,79 & 0 & 24.119 .071 & 0 & 149,00 & 0 & 131,57 & 0 & 0,94 & 0 & 0,96 & 0 \\
\hline 84 & 5,97 & 1 & 0 & 0,77 & 0 & 23.036 .377 & 0 & 124,20 & 0 & 137,23 & 0 & 0,75 & 0 & 1,01 & 0 \\
\hline 85 & 7,18 & 1 & 0 & 0,86 & 0 & 28.182 .717 & 0 & 125,87 & 0 & 159,85 & 0 & 0,74 & 0 & 1,09 & 0 \\
\hline 86 & 8,53 & 1 & 0 & 0,98 & 0 & 25.326 .018 & 0 & 127,24 & 0 & 140,63 & 0 & 0,77 & 0 & 1,15 & 0 \\
\hline 87 & 8,47 & 1 & 0 & 1,10 & 0 & 31.612 .516 & 0 & 105,01 & 0 & 162,45 & 0 & 0,61 & 0 & 1,21 & 0 \\
\hline 88 & 5,27 & 0 & 1 & 0 & 1,14 & 0 & 30.186 .561 & 0 & 101,20 & 0 & 169,53 & 0 & 0,56 & 0 & 1,16 \\
\hline 89 & 6,06 & 0 & 1 & 0 & 1,32 & 0 & 29.161 .824 & 0 & 104,86 & 0 & 178,25 & 0 & 0,77 & 0 & 1,22 \\
\hline 90 & 5,52 & 0 & 1 & 0 & 1,18 & 0 & 27.832 .022 & 0 & 80,18 & 0 & 168,57 & 0 & 0,65 & 0 & 0,95 \\
\hline 91 & 6,54 & 0 & 1 & 0 & 1,04 & 0 & 27.930 .217 & 0 & 79,83 & 0 & 175,60 & 0 & 0,64 & 0 & 1,08 \\
\hline 93 & 4,88 & 0 & 1 & 0 & 0,94 & 0 & 33.577 .720 & 0 & 88,55 & 0 & 181,25 & 0 & 0,75 & 0 & 0,90 \\
\hline 94 & 4,84 & 0 & 1 & 0 & 1,01 & 0 & 36.689 .718 & 0 & 67,06 & 0 & 197,21 & 0 & 0,74 & 0 & 0,97 \\
\hline 95 & 8,06 & 0 & 1 & 0 & 0,85 & 0 & 40.545 .785 & 0 & 76,29 & 0 & 201,88 & 0 & 0,64 & 0 & 0,86 \\
\hline 96 & 7,89 & 0 & 1 & 0 & 0,91 & 0 & 43.306 .941 & 0 & 82,69 & 0 & 207,49 & 0 & 0,94 & 0 & 0,92 \\
\hline
\end{tabular}




\section{APÊNDICE 3}

Regressões alternativas para os salários dos diarista: 
a) 1"a opç̃o, usando os logaritmos dos dados e "quebra" de tendência em 1988;

$1^{0}$ periodo $(1977-87)$

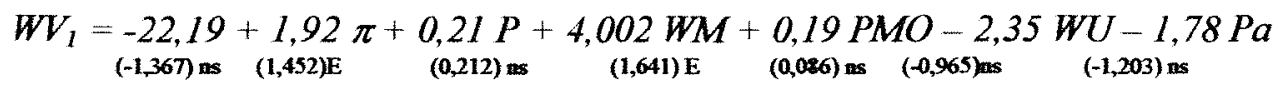

$2^{\underline{0}}$ período (1988-96)

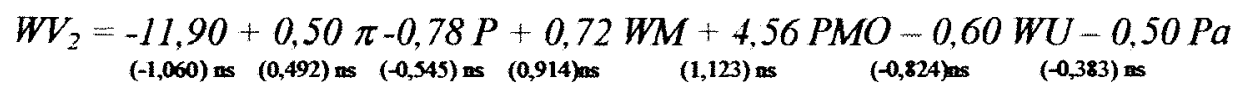

$\mathrm{R}^{2}=0,848 \quad \mathrm{n}=20 \quad \mathrm{~F}=2,572^{\mathrm{E}} \quad \mathrm{DW}=1,722$ (inconclusivo) $\quad \mathrm{Q}(5-0)=13,376^{\mathrm{C}}$

b) $2^{\mathfrak{z}}$ opção, usando os logaritmos dos dados e "quebra" de tendência em 1988 excluindo a constante, e;

$1^{0}$ periodo $(1977-87)$

$W V_{l}=1,24 \pi-0,81 P+1,34 W M+1,94 P M O-0,05 W U-0,78 P a$ $(0,952)$ as $\quad(-1,156)$ us $\quad(0,861)$ as $\quad(1,000)$ ns $\quad(-0,026)$ ns $\quad(-0,573)$ us

$2^{\underline{0}}$ periodo $(1988-96)$

$W V_{2}=0.16 \pi-1,26 P+0,36 W M+4,20 P M O-0.24 W U-0,22 P a$ $(0,155)$ ns $\quad(-0,873)$ ns $\quad(0,479)$ ns $\quad(0,979)$ as $\quad(-0,346)$ as $\quad(-0,164)$ ns

$\mathrm{R}^{2}=0,772 \quad \mathrm{n}=20 \quad \mathrm{DW}=1,520$ (inconclusivo) $\quad \mathrm{Q}(5-0)=9,792^{\mathrm{D}}$

c) $3^{2}$ opção, usando os dados sem logaritmo e mudando a "quebra" de tendência para o ano de 1987.

$1^{\circ}$ periodo $(1977-87)$

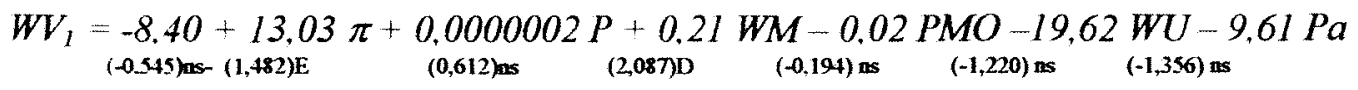

$2^{\circ}$ periodo (1988-96)

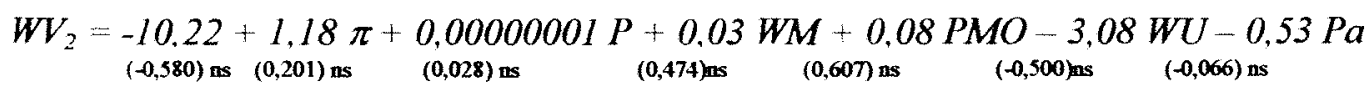

